Evaluation of the Impact of Skills for Life Learning: Longitudinal Survey of Learners, Wave 3

Pamela Meadows and Hilary Metcalf NIESR 
Research Report

No 824

\section{Evaluation of the Impact of Skills for Life Learning: Longitudinal Survey of Learners, Wave 3}

Pamela Meadows and Hilary Metcalf

NIESR

The views expressed in this report are the authors' and do not necessarily reflect those of the Department for Education and Skills. 


\section{Acknowledgements}

This evaluation was only possible due to the hard work and contributions of a large number of people, whom we would like to thank. In particular, we would like to thank Nick Coleman and Hannah Carpenter of BMRB, who helped design the survey and who managed the fieldwork, and the BMRB fieldforce who negotiated access to learners and conducted the interviews. We would also like to thank all the people who participated in the survey for so generously subjecting themselves to a lengthy interview and to literacy and numeracy tests. Secondly, we would like to thank the other researchers and academics who contributed to the study and, in particular, Peter Burke (Centre for Developing and Evaluating Lifelong Learning, University of Nottingham) for developing the short literacy and numeracy test for use in the survey; Maria Kambouri (Institute of Education, London University) for advice on literacy and numeracy testing; and Peter Warr (Institute of Work Psychology, Sheffield University) for advising on work commitment measures and to John Bynner and Leon Feinstein (both Institute of Education, London University) and Greg Brooks who provided useful comments from the Steering Group. Finally, we are very grateful to the research team at the DfES, Richard White, Andrew Lincoln and Gail Peachey, whose support and positive approach helped the research through its more difficult stages. Their cheerful demeanour made it a pleasure to work with them. 


\section{Contents}

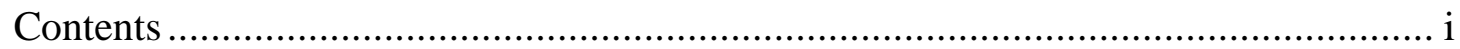

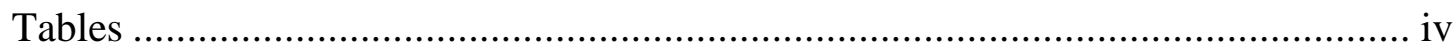

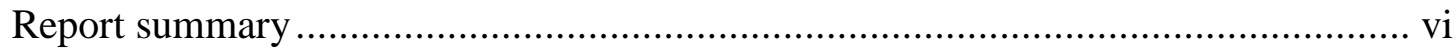

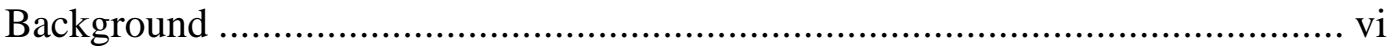

The evaluation ........................................................................................... vi

The impact of Skills for Life courses on participants............................................. vi

New course start-up and progression for Skills for Life learners........................... vii

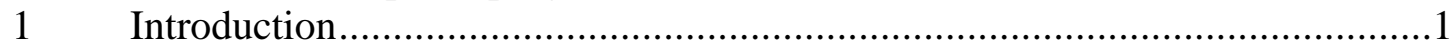

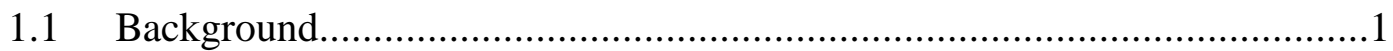

1.1.1 Policy background................................................................................

1.1.2 The introduction of the Skills for Life programme................................1

1.2 Previous evidence relating to the impact of basic skills programmes ...........2

1.2.1 The impact of basic skills programmes on basic skills ..........................2

1.2.2 The impact of basic skills acquisition on employment .........................2

1.2.3 The impact of basic skills acquisition on training...................................

1.3 The impact evaluation ..............................................................................

2 Characteristics of Skills for Life learners responding to Wave 3 .......................

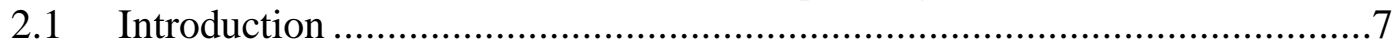

2.2 Courses being pursued ............................................................................

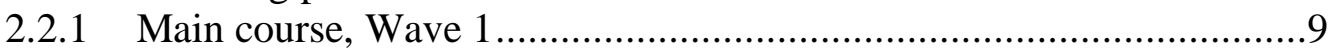

$2.3 \quad$ Personal and familial characteristics.........................................................11

2.3.1 Family composition and children.....................................................11

2.3.2 Ethnicity...............................................................................12

2.3.3 First language.............................................................................12

2.3.4 Health and disability....................................................................12

2.3.5 Satisfaction with life..........................................................................13

$2.4 \quad$ Skills and economic activity....................................................................13

2.4.1 Literacy and numeracy competence...................................................13

2.4.2 Qualifications and schooling ........................................................14

2.4.3 Economic activity...........................................................................16

3 Impact of participation on a Skills for Life course ........................................17

3.1 The aim of the impact analysis ...............................................................17

3.2 The evaluation approach ......................................................................17

3.2.1 Matching ……………………………………………………....18

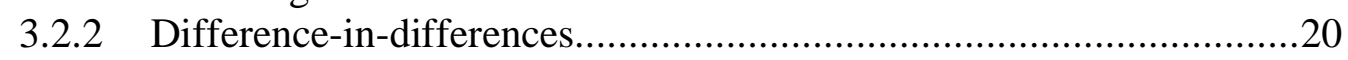

3.2.3 Bootstrapping ..............................................................................20

3.3 What this study is measuring....................................................................20

3.4 Key findings from the present study compared with previous studies .........21

3.5 Detailed outcomes..............................................................................23

3.5.1 Perceived improvements in literacy and numeracy …………………...23

3.5.2 Labour market outcomes ...............................................................27

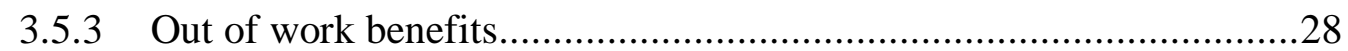

3.5.4 Health and disability outcomes.......................................................29 
3.5.5 Activities with children ..............................................................29

3.5.6 Self-esteem and life satisfaction .................................................30

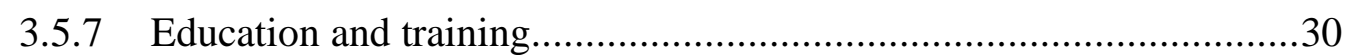

3.6 Associations between Wave 2 outcomes and Wave 3 outcomes .................32

3.6.1 Attitudes to education and training and subsequent participation in

education and training courses ................................................................32

3.6.2 Self-perceived improvement in numeracy and literacy and earnings ..32

3.7 Overall conclusions of the impact study ...............................................33

$4 \quad$ Skills for Life learners: progression in education and training.........................34

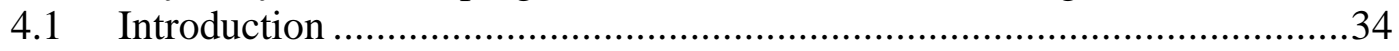

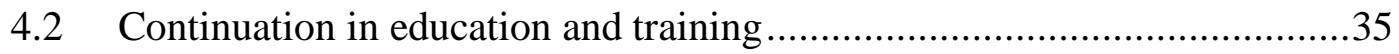

4.2.1 Participation in education and training.........................................35

4.2.2 New courses and course continuation .............................................36

4.2.3 Combining new courses and continuing courses ..............................37

4.3 New course characteristics, Years 2 and 3 ............................................38

4.3.1 Changes in the characteristics of courses ........................................38

4.3.2 Participation in new courses ....................................................4

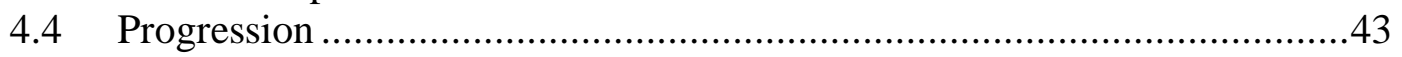

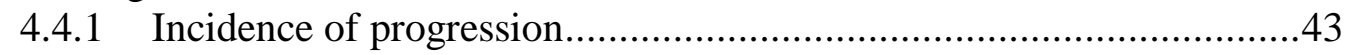

4.4.2 Progression: types of courses of those progressing.........................45

4.4.3 Progression: participation in higher level new courses ......................47

4.5 Factors affecting continuation and progression....................................49

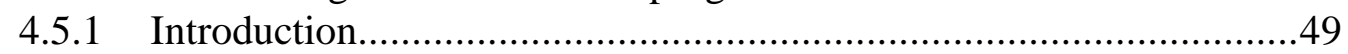

4.5.2 Factors affecting progression: Wave 1 courses ..............................49

4.5.3 Factors affecting progression: Education, skills and qualifications.....50

4.5.4 Factors affecting continuation and progression: Personal characteristics

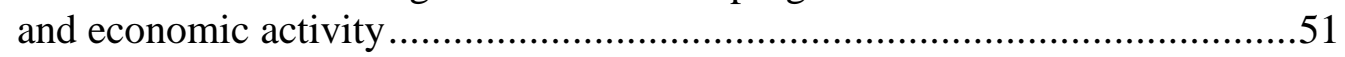

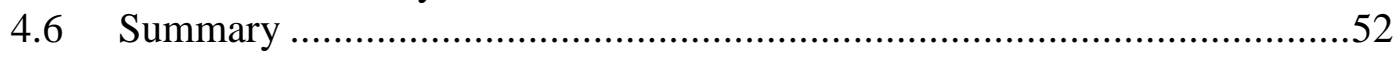

4.6.1 Summary: continued participation in education and training..............52

4.6.2 Summary: new courses and progression ......................................5

4.6.3 Summary: factors affecting progression.........................................53

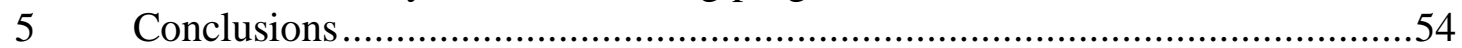

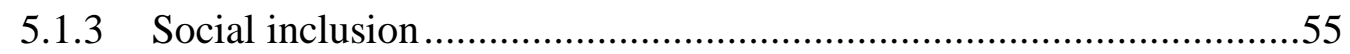

Appendix 1: Wave 3 Survey Technical Report .................................................56

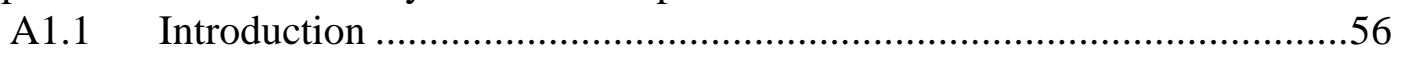

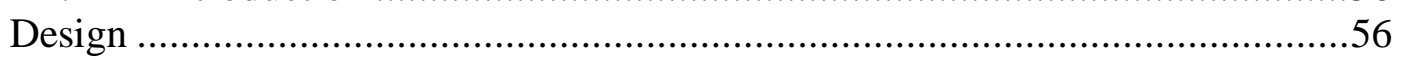

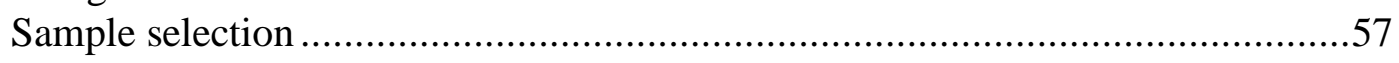

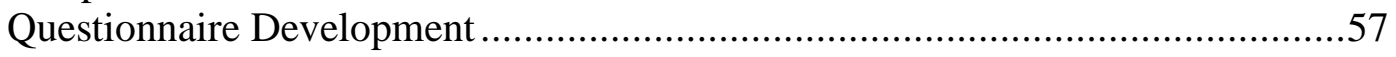

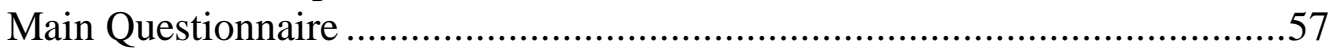

Literacy and Numeracy Tests .............................................................5

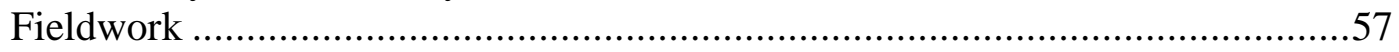

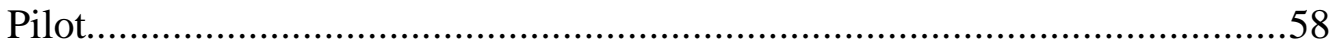

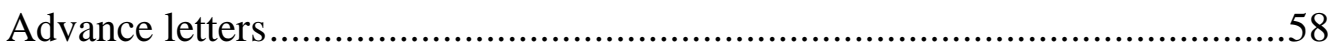

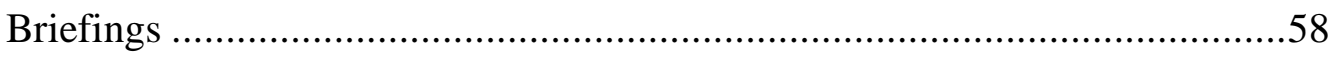

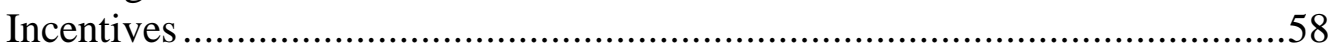

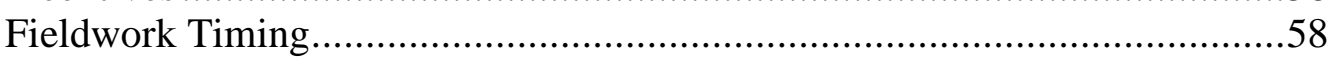

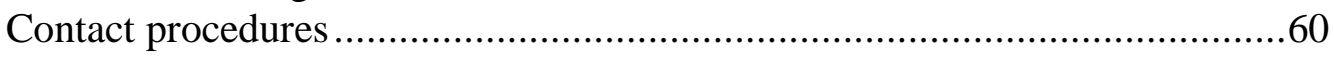

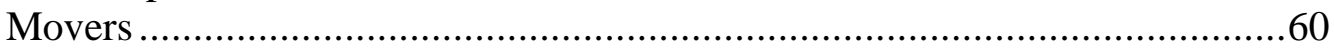

Quality Control Measures.......................................................................60

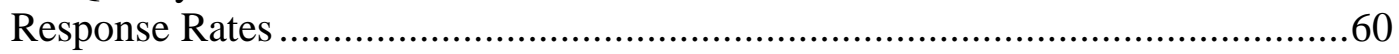




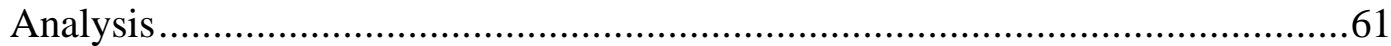

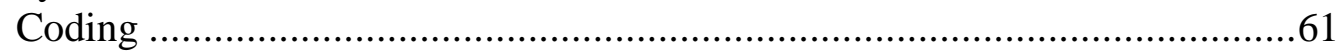

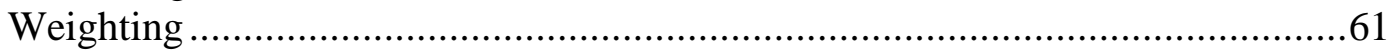

Appendix 2: Logistic regression equation used for propensity score matching ..........64

Appendix 3: New courses and progression .......................................................6

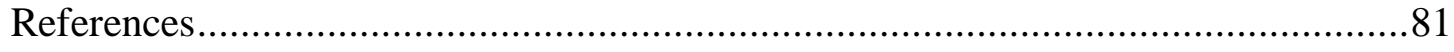




\section{Tables}

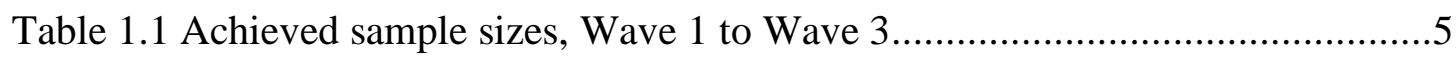

Table 2.1 Skills for Life learners: all courses, type of qualifications pursued at Wave 1

Table 2.2 Skills for Life learners: all courses, highest qualification level pursued at Wave 1

Table 2.3 Skills for Life learners: main course, literacy and numeracy content, Wave 1

Table 2.4 Skills for Life learners: main course, type of qualification pursued at Wave 1

Table 2.5 Skills for Life learners: main course, qualification level pursued at Wave 1

Table 2.6 Skills for Life learners: main course, reason for doing course at Wave 1 ...11

Table 2.7 Skills for Life learners: age .11

Table 2.8 Skills for Life learners: family composition .............................................12

Table 2.9 Skills for Life learners: ethnicity ............................................................12

Table 2.10 Skills for Life learners: satisfaction with life ..........................................13

Table 2.11 Skills for Life learners: literacy and numeracy competence......................14

Table 2.12 Skills for Life learners: self-assessed literacy and numeracy problems .....14

Table 2.13 Skills for Life learners: prior qualifications ...........................................15

Table 2.14 Skills for Life learners: schooling .......................................................15

Table 2.15 Skills for Life learners: main economic activity at Wave 1.....................16

Table 4.1 New and higher-level courses by continuation of Year 1 courses ..............38

Table 4.2 New course starters: new course qualification, Years 2 and 3..................40

Table 4.3 New course starters: highest new course qualification level Years 2 and 340

Table 4.4 New course participation, new course qualification, Years 2 and 3............42

Table 4.5 New course participation, highest new course qualification, Years 2 and 342

Table 4.6 Progression to higher-level courses, Years 2 to 3 ...................................43

Table 4.7 Progression: highest course level, Years 1 to 3......................................44

Table 4.8 Progression, Years 2 to 3, by Wave 1 course level ...................................45

Table 4.9 Progression: courses of those progressing to higher-level courses, Years 2

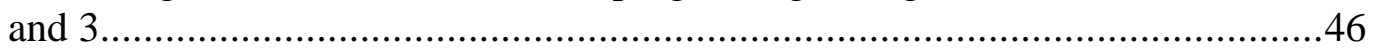


Table 4.10 Progression: incidence of new course types and progression to higher-level

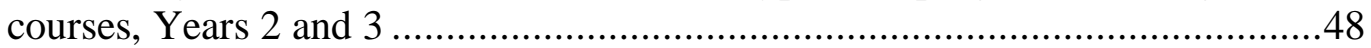

Table A1. 1 Response rates for all respondents ..................................................60

Table A1. 2 Response rates: learners and control sample ......................................61

Table A1. 3 Weights to adjust for non-response between Waves 1 and 3 - Learners

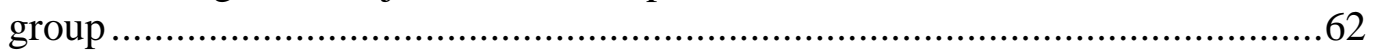

Table A1. 4 Rim weights to adjust for non-response between Wave 1 and Wave 3 -

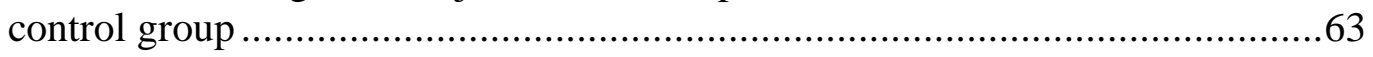

Table A1. 5 Weights by age to adjust for non-response between Wave 1 and Wave 3 -

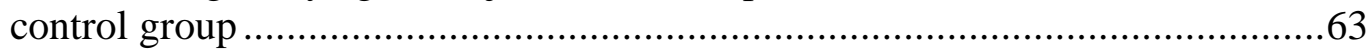

Table A2. 1 Logistic regression equation used for propensity score matching...........64

Table A2. 2 Effect of Propensity Score Matching on Differences between Learners

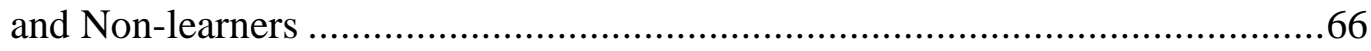

Table A3.1 Factors affecting starting a new course at Wave 2 ...............................68

Table A3.2 Factors affecting starting a new higher-level course at Wave 2..............70

Table A3.3 Factors affecting starting a new course at Wave 3 ................................72

Table A3.4 Factors affecting starting a new higher-level course at Wave 3...............74

Table A4.1 Wave 3 outcomes 74 


\section{Report summary}

\section{Background}

The Skills for Life programme is designed to improve literacy, numeracy and language skills of adults and of young people (aged 16 to 17) who had left full-time education. As part of the programme, literacy, numeracy and ESOL training was provided free of charge to those without literacy or numeracy qualifications at Level $2^{1}$.

\section{The evaluation}

This report is the third in a series of reports of the evaluation of the impact of participation in a literacy or a numeracy course at a college for a qualification. As such, the evaluation does not assess the full Skills for Life programme (notably excluding ESOL courses and courses delivered outside college). The analysis is restricted to those aged 19 and over. (Descriptive information is provided on 16 to 18 year olds in the reports of Wave 1 and Wave 2, see Metcalf and Meadows, 2005, for Wave 1 and Meadows and Metcalf, 2005, for Wave 2).

The evaluation examines the impact of participation on a range of economic, personal and social outcomes, including employment, health and involvement in one's children's education (at Wave 2 and Wave 3). It also describes course benefits, as perceived by the participants (at Wave 2), factors affecting qualification gain and dropout (at Wave 2) and progression in education and training (at Wave 3). The first report described the characteristics of participants and their courses and identified factors affecting participation in Skills for Life literacy and numeracy courses (Metcalf and Meadows, 2005).

The evaluation is being conducted through a longitudinal survey of participants on literacy and numeracy courses (Skills for Life learners) and a matched group of non-participants with low or no literacy or numeracy qualifications. A shorttest-based assessment administered prior to interview confirmed respondents to be lacking literacy or numeracy skills at Level 2. Respondents were first interviewed in 2002/03 (when course participants were on their course), with second and third wave interviews taking place one and two years later, respectively. This report provides findings based on analysis of the first three waves of the survey.

\section{The impact of Skills for Life courses on participants}

Skills for Life courses do have an impact, and this is likely to increase.

${ }^{1}$ Approximately equivalent to GCSE Grades A*-C. Since the evaluation started, the eligibility criteria have changed. Current eligibility for the programme is based upon an assessment exercise to test that those without a Level 2 literacy or numeracy qualification are indeed in need of developing these skills. 
An important impact relates to lifelong learning. Adults with poor basic skills have often not had good experiences at school, and it is known that those with poor school experiences are difficult to attract back into learning as adults. Yet those who had taken literacy or numeracy courses have become more positive in their attitudes towards the value of education and training, and a large proportion have gone on to take new courses (many of them full-time).

This active engagement with full-time education on the part of the former Skills for Life learners means that although their employment rates have been higher (and the differences with the comparison group larger) at each successive wave of the study, the differences from non-Skills for Life learners are not statistically significant. It is, however, reasonable to expect that some of those currently taking education and training courses will move into employment over the next few years.

Whilst, at this stage, Skills for Life had not increased employment, it did have a positive effect on net earnings as learners increased their average annual take-home pay two years on, compared to non-learners whose average annual income fell.

\section{New course start-up and progression for Skills for Life learners}

Skills for Life learners tended to continue their education and training, through continuing previous courses and starting new ones:

72 per cent were on a course one year later (at Wave 2) and 57 per cent were on a course two years later (at Wave 3);

64 per cent had started a new course for a qualification within the following two years (by Wave 3) (47 per cent by Wave 2, and 40 per cent between Wave 2 and Wave 3).

In starting new courses and progressing to higher-level courses Skills for Life learners tended to move from basic skills courses to vocational courses, in particular, and, to a lesser extent, to academic courses. Nevertheless, some started new basic skills courses.

Skills for Life seemed to provide an effective stepping stone to progression, i.e. for moving to courses at a higher qualification level:

30 per cent of Skills for Life learners had done a new course by Wave 3 that was at a higher level than any of those undertaken at Wave 1.

Progression was most common in the first year.

Skills for Life appeared particularly effective for those least skilled in literacy and numeracy, as progression increased as course level decreased. At the same time, those who were most likely to progress were not necessarily the least qualified, as those with other prior qualifications at level 3 (at Wave 1) were also more likely to progress. Similarly, those who had stayed in full-time education beyond the age of 18 were also more likely to progress.

The findings emphasise the importance for progression of positive outcomes from courses: completion is most important and qualification gain less so.

Personal characteristics, other than health, had little or no effect on course continuation or progression, suggesting that Skills for Life was assisting diverse people equally. 


\section{Introduction}

\section{$1.1 \quad$ Background}

\subsubsection{Policy background}

'Roughly $20 \%$ of adults - that is perhaps as many as 7 million people - have more or less severe problems with basic skills, in particular with what is generally called 'functional literacy' and 'functional numeracy': "the ability to read, write and speak in English, and to use mathematics at a level necessary to function at work and in society in general"'. ('The Moser Report', DfES, 1999)

The impact of poor basic skills on individual lives is far-reaching. Unemployment, temporary work and chequered job histories are more common and earnings lower (Dearden et al., 2000; McIntosh and Vignoles, 2001; Ekinsmyth and Bynner, 1994; Bynner and Parsons, 1997a; Bynner and Parsons, 1997b). Women tend to have children at a younger age and withdraw from the labour market (Bynner et al., 2001). Physical and mental health tends to be worse and participation in community life and politics is less common (DfEE, 1999). Moreover, basic skills difficulties may transfer to the next generation due to parents having problems reading to their children and helping them with their schoolwork (DfEE, 1999).

Concern over the levels of literacy and numeracy in the population, their effect on individuals and their effect on the economy prompted the establishment of a government inquiry, chaired by Claus Moser, into basic skills in 1998 (DfES, 1999). It reported that 20 per cent of adults had "more or less severe problems with basic skills" and recommended a target of halving the number of functionally illiterate adults over a decade (DfEE, 1999). Forty percent of adults were considered as having major problems with numeracy and Moser recommended that this figure should be reduced to 30 per cent over the same time period (DfES, 1999).

\subsubsection{The introduction of the Skills for Life programme}

In response to the Moser Report, in 2001 the government established 'Skills for Life' a long-term programme for adults to improve literacy, numeracy and communication. The programme is aimed at a wider group of people than those suffering functional literacy and numeracy problems identified by Moser. It seeks to increase participation in, and the effectiveness of, literacy, numeracy and communication courses for those without Level 2 qualifications in literacy and numeracy. As part of the programme, literacy and numeracy courses for those without Level 2 qualifications in these subjects are provided free. About half of the working age population are eligible for such courses (see Metcalf and Meadows, 2005). Further details of the background to the programme can be found in the Report of Sweep 1 (Metcalf and Meadows, 2005). 
The programme was established both to improve basic skills, but also to improve employment and other aspects of individuals' lives. NIESR and BMRB were commissioned to conduct an evaluation of the impact (and cost-effectiveness) of the Skills for Life programme, in relation to literacy and numeracy training. The evaluation is largely concerned with the wider benefits of Skills for Life participation (primarily employment, further learning, health, social participation and participation in children's education), rather than with the effect on literacy and numeracy competence. It uses a longitudinal design, tracking Skills for Life participants and a similar group of non-participants. This report presents findings of the impact two years after participation in the Skills for Life course.

\subsection{Previous evidence relating to the impact of basic skills programmes}

How effective should we expect the Skills for Life programme to be? Few robust studies exist of the impact of adult basic skills training on literacy and numeracy competence or on wider outcomes (such as employment and health). Most have been small-scale and qualitative, whilst the quantitative studies have tended to describe changes amongst the learners rather than measure change against a comparison group. The more robust research tends to show few effects. Moreover, analyses of the benefits of improved literacy and numeracy tend to assume that the return to basic skills competences and qualifications are the same whether these were gained during continuous full-time education or gained at a later stage.

\subsubsection{The impact of basic skills programmes on basic skills}

Certainly, the evidence suggests that adult literacy or numeracy courses may not lead to higher literacy and numeracy competence. Even where people report significant differences in their ability to manage their daily lives (to write notes for their work or complete official forms, for example) this is not generally detectable using standard well-established tests (Fingeret and Danin, 1991; Fingeret, 1985; Heath, 1983; Fingeret and Drennon, 1997; Rahmani et al., 2002). The notable exception to this general picture is Brooks et al (2001a) which used very detailed tests and found differences in some areas of competence.

Beder (1999) and McIntosh (2004), in reviewing previous evaluations of literacy training programmes found a dearth of robust evidence of the impact: most research suffered from major methodological problems, notably, the lack of a robust (or any) counterfactual; most were qualitative and relied on trainees' perceptions of effects. From the evidence, Beder felt able to conclude only that "it is likely" that literacy participants made gains in employment, wages, continued education and in self-image. However, only two of the reviewed studies of employment impacts used comparison groups, with one reporting negative and the other positive effects. Beder was agnostic about whether these gains could have stemmed from literacy improvement: it was unclear from the reviewed studies whether basic skills training improved basic skills.

\subsubsection{The impact of basic skills acquisition on employment}

Even if training does improve literacy and numeracy skills, it cannot be assumed that gaining these skills as an adult has the same effect on employment as gaining them during compulsory (or full-time continuous) education. Indeed, the effect on employment and earnings of improvements in literacy and numeracy during 
adulthood (as opposed to adult participation on courses) appears to be weak. Dearden et al (2000) report a six per cent increase in earnings from improving numeracy skills to Level 1 (where the improvement took place between the ages of 16 and 37). They find no effect for increasing literacy to Level 1. Machin et al. (2001), using a comparison group approach to examine the impact on employment and wages of improvements in literacy and numeracy skills between the age of 33 and the age of 37 found wage effects (for those with low basic skills) only for men whose numeracy had improved. They found no effect on employment, nor an effect for women, nor for literacy improvement. Denny et al. (2003) used the International Adult Literacy Survey to estimate the relationship between functional literacy and earnings and they found that moving from a level of functional literacy below level 1 to a higher level had only a small effect on earnings (an increase of around 5 per cent). However, they found that in the United States the rate of return from moving from very low levels of functional literacy to higher levels was much greater than in other countries (of the order of 30 per cent).

However, Machin et al. (2001) report improvements in both earnings and employment for both men and women if they perceive that they have improved their literacy and numeracy (between the age of 33 and the age of 37).

Our evaluation of the impact after one year of participation in Skills for Life also showed little effect, with no discernible improvement in employment amongst Skills for Life participants compared with the comparison group (Meadows and Metcalf, 2005). However, a number of factors associated with employability (selfesteem, attitudes towards education and training, employment commitment and longterm illness of disability) had improved to a greater degree amongst Skills for Life participants than non-participants. Moreover, over half of Skills for Life participants had achieved a qualification from their literacy or numeracy course, whilst threequarters believed the course had improved their literacy or numeracy.

\subsubsection{The impact of basic skills acquisition on training}

Whilst literacy and numeracy skills may only have a limited direct effect on employment success, at lower levels, newly acquired skills may be building blocks to the development of skills relevant to the workplace, including though progression in further education and training. Certainly, Skills for Life participants showed an increased commitment to education and training compared with similar people who had not been on a Skills for Life course (Meadows and Metcalf, 2005). The OECD (2000) found that people with higher levels of literacy were more likely to take part in employer-organised training than those with lower literacy levels even where they had the same qualification levels. In addition, improving literacy and numeracy is likely to lead to greater self-confidence, which also tends to develop cumulatively. Employment and earnings effects are more likely to come through later as enhanced literacy and numeracy allows people to develop skills that more directly influence their employment and earnings prospects. (See for example, Boe 1997, Bonjour and Smeaton 2003, Bynner et al 2001). To test these theories, the evaluation two years after participation in Skills for Life courses examined course progression as well as employment and other effects. 


\subsection{The impact evaluation}

The NIESR/BMRB evaluation of the Skills for Life programme, is restricted to the impact of literacy and numeracy training (i.e. ESOL, although part of the programme, is excluded). The evaluation focuses on the impact on individuals who have taken part in a college course in literacy or numeracy (for a qualification), including the impact on economic activity, employment, earnings, participation in further training and health as well as 'softer' outcomes, such as the impact on selfesteem, work commitment and involvement in their children's education and wider society. Because the time available in the interview was limited, those taking part in the study took only a very short literacy and numeracy test. The tests were designed to be sufficiently sensitive to detect low levels of literacy and numeracy, but not sufficiently sensitive to detect small changes.

Overall the approach may be seen as a 'black-box' evaluation: we do not assess or identify the impact on literacy and numeracy competence, but move to final outcomes, such as employment and health. Whilst this is a standard approach to impact evaluation, the evidence cited above of the low identified impact of adult basic skills training on literacy and numeracy competence and the identified effects on employability make it particularly pertinent. However, this does leave unaddressed the process by which adult literacy and numeracy training might affect wider outcomes and whether the Skills for Life programme does improve basic skills. For example, is there a simple process by which training improves literacy and numeracy skills and these (directly or via qualification gain) improve employability ((Figure 1.1, Model a))? However, since the, albeit limited, evidence has not found that adult basic skills training increases basic skills competence, it seems unlikely that the effect on employability is through improved literacy and numeracy skills. Alternatively, does participation in basic skills training increase other aspects of employability (such as motivation and self-esteem) and thus improve employment directly (and, possibly indirectly, through improvements in basic skills as well) (Figure 1.1, Model b))?

The impact evaluation is being conducted through a longitudinal survey of people who were participating in literacy or numeracy courses aimed at gaining a qualification in colleges (excluding ESOL) (referred to as the 'Longitudinal Learners' Survey') and of a matched comparison group of people with people with similar literacy and numeracy skills and qualifications who were not participating in Skills for Life courses for a qualification. The comparison sample was drawn from a number of sources $^{2}$, with the sample restricted, variously, to those with low (or no) literacy or numeracy qualifications (always below Level 2 in either literacy or numeracy) or those with low tested literacy or numeracy skills (again either literacy or numeracy below Level 2). The achieved sample sizes for each wave are shown in Table 1.1.

2 From the National Adult Learning Survey, from the Skiths for Life Survey and from a household survey. See Metcalf and Meadows (2005) for full details. 
Figure 1.1 Models of basic skills training effects on employability

a) Direct effects on employability, with black box

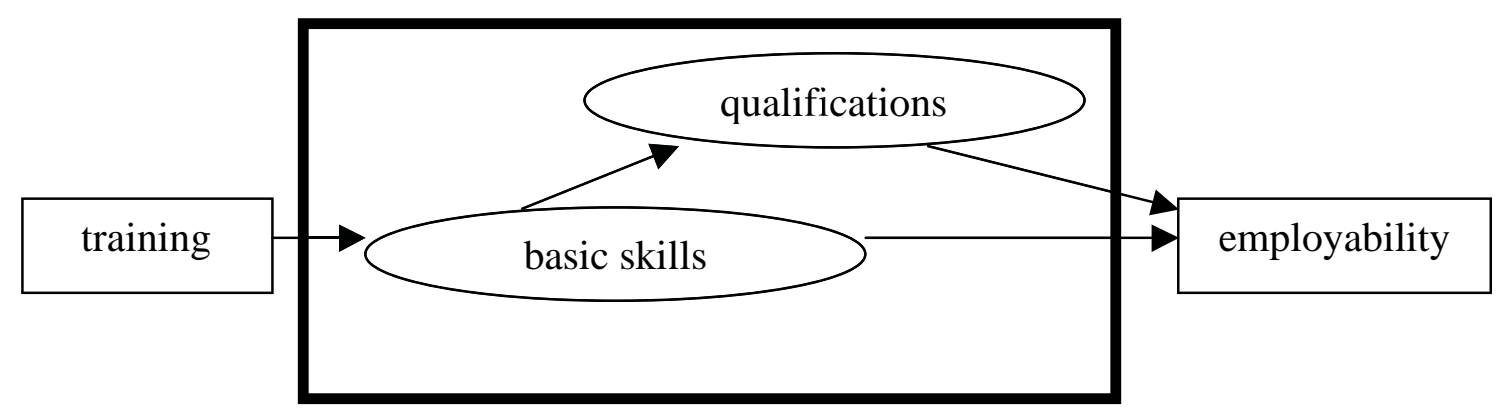

b) Indirect effects on employability, with black box

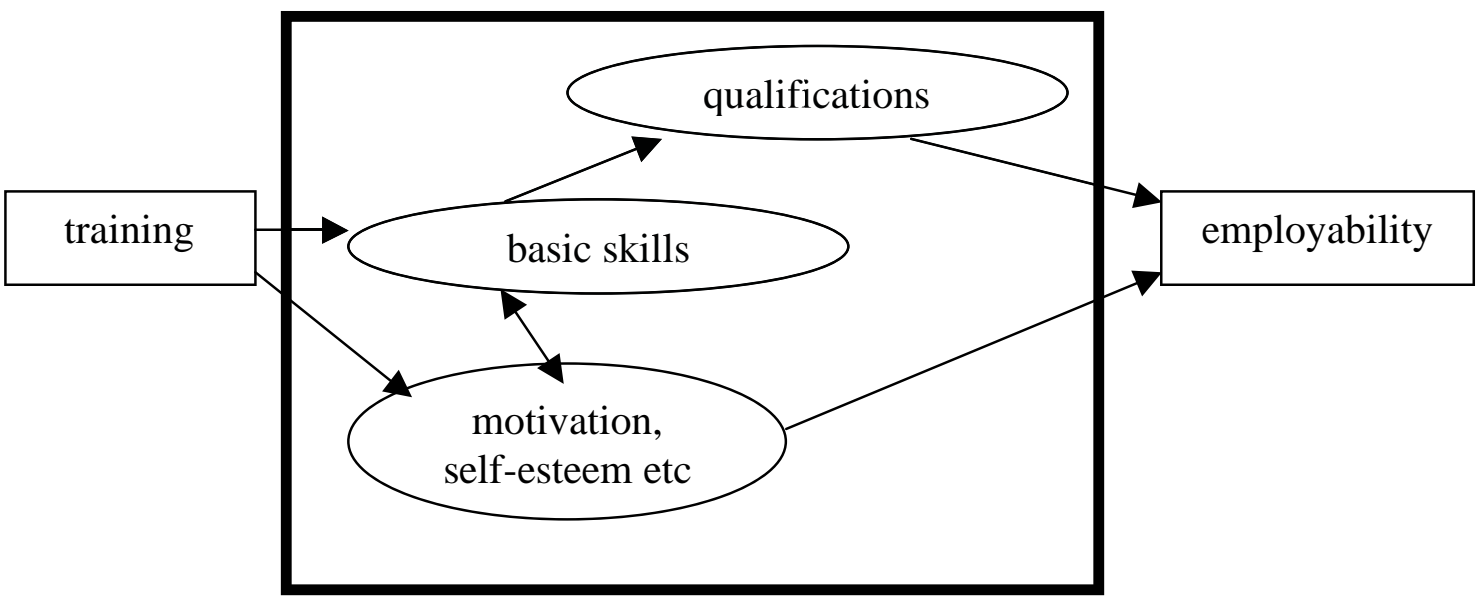

Table 1.1 Achieved sample sizes, Wave 1 to Wave 3

\begin{tabular}{|l|c|c|}
\hline & Skills for Life learners & comparison group \\
\hline Wave 1 & 1990 & 2255 \\
\hline Wave 2 & 1094 & 1122 \\
\hline Wave 3 & 682 & 674 \\
\hline
\end{tabular}

Note that the comparison group is used in the impact analysis only, which uses a matched comparison method. The matching did not result in the full comparison sample being used.

The first sweep of the survey was conducted between September 2002 and July 2003 and provides a base line from which the effects of literacy and numeracy training can be measured. The second sweep was conducted January to August 2004 and the third sweep between January and June 2005, with respondents being interviewed as close as possible to a year and two years, respectively, after their initial interview. Further details of the survey are given in Metcalf and Meadows (2005) and 
in Appendix 1 of this report. A fourth survey sweep is taking place a year after the third.

Analysis of the first sweep of the Longitudinal Learners' Survey was reported in 'Evaluation of the impact of basic skills learning Report on Sweep 1' (Metcalf and Meadows, 2005). This provided a detailed description of the personal characteristics and courses of a representative sample of Skills for Life learners who were on college courses leading to a qualification. The report also uses the Skills for Life Survey to provide a description of the population eligible for Skills for Life and to identify factors which affected participation in literacy and numeracy courses.

Analysis of the second sweep was reported in Meadows and Metcalf (2005). This report focussed on impact after one year (discussed above, p11), perceived benefits of the course, qualification gain and dropout. Analysis was confined to those aged 19 years old or over at the time of their Wave 1 interview. This was because of major differences (educational, personal and economic activity) between those aged 19 and over and those under 19, making it inappropriate to analyse all ages together, whilst sample size restrictions precluded separate analysis.

This report, of impact after two years, is also restricted to those aged 19 and over at Wave 1. As well as assessing the wider impact of participation in a Skills for Life course two years on, the report explores continued participation in learning and progression for those who were on Skills for Life courses. This was due to our earlier finding that participation in Skills for Life increased commitment to education and training and due to our previous tentative conclusion that, for this group, participation in basic skills courses might be an early, rather than final, training step on the road to employment (Meadows and Metcalf, 2005).

As background to the analysis, the next chapter provides a brief description of the characteristics of Skills for Life learners interviewed at Sweep 3, including a description of change for some of the main outcome variables. (For a full description of the characteristics of Skills for Life learners, readers are referred to 'Evaluation of the impact of basic skills learning Report on Sweep 1' (Metcalf and Meadows, 2005)).

Chapter 3 analyses the impact of participation in a literacy or numeracy course through comparing outcomes for Skills for Life learners and a comparison group of non-Skills for Life learners. Outcomes examined include satisfaction with life, selfesteem, perceived improvement in literacy and numeracy, attitudes towards education and training, economic status, health and assistance provided to one's children.

Chapter 4 focuses on the Skills for Life learners are explores their continuation to other courses and progression to higher-level courses.

The final chapter, brings together the findings to draw general conclusions about Skills for Life.

Note that throughout the report reference to age is to age at the time of the Wave 1 interview (e.g. those referred to as 19 to 24 year olds are, at Wave 3, 21 to 26 year olds). 


\section{Characteristics of Skills for Life learners responding to Wave 3}

\subsection{Introduction}

This section describes the main characteristics of literacy and numeracy learners aged 19 and over (at Wave 1) (A fuller description of the characteristics of the learners who took part in Wave 1 is provided in Metcalf and Meadows, 2005.) The original sample was representative of 19 to 65 year olds pursuing a course which leads to a literacy or numeracy qualification at college.

It also provides comparative information about those who took part at Wave 3. This shows that Wave 3 respondents were very similar to the representative sample at Wave 1, suggesting that little response bias had occurred and that the findings of the analysis of Wave 3 was likely to be a good indicator of outcomes for all Skills for Life learners.

Tables report data for the full sample at Wave 1 and at Wave 3. The text describes the data from Wave 1.

\subsection{Courses being pursued}

By definition, all Skills for Life learners were pursuing a literacy or numeracy course for a qualification at college when they were first interviewed. This was the course which led to their inclusion in the Skills for Life learners sample and is referred to in the report as their 'main course'. This main course was either for a literacy or numeracy qualification or for a more general qualification which included a basic skills qualification (such as an NVQ). However, many Skills for Life learners (48 per cent) had been undertaking other courses, in addition to their main course, when they were first interviewed. These included other literacy and numeracy courses and nonliteracy or numeracy courses.

In this section, first, the full range of courses being pursued by the Skills for Life learners is described. This is followed by a description of the main course. The data refer to courses being undertaken when first interviewed.

Two-thirds of Skills for Life learners were doing a course for a literacy qualification (including, for example, GCSE in English) and almost half a numeracy course. Nearly one sixth were doing a Key Skills qualification (Table 2.1).

Vocational qualifications were more common (39 per cent) than academic (32 per cent). However, GCSE was the most common qualification being pursued (by 26 per cent), with 16 per cent doing GCSE English and 15 per cent doing GCSE Maths. Sixteen per cent were doing City and Guilds courses and ten per cent CLAIT or other IT. Fewer than five per cent of learners were doing any other type of qualification. 
Table 2.1 Skills for Life learners: all courses, type of qualifications pursued at Wave 1 per cent Skills for Life learners

\begin{tabular}{|c|c|c|}
\hline & Wave 1 & Wave 3 \\
\hline Basic skills & $87^{\mathrm{a}}$ & 85 \\
\hline Literacy qualification (all) & 67 & 65 \\
\hline Numeracy qualification (all) & 44 & 47 \\
\hline combined literacy and numeracy & 3 & 4 \\
\hline Key skills qualification (all) & 18 & 16 \\
\hline ESOL & 2 & 1 \\
\hline Academic & 29 & 32 \\
\hline GCSE & 28 & 26 \\
\hline \begin{tabular}{l|l} 
GCSE English \\
\end{tabular} & 16 & 16 \\
\hline GCSE Maths & 14 & 15 \\
\hline A or AS Levels/ Access course & 2 & 2 \\
\hline degree, HND, nursing, teaching & 2 & 2 \\
\hline Vocational & 36 & 39 \\
\hline City and Guilds & 19 & 16 \\
\hline CLAIT/other IT & 9 & 10 \\
\hline NVQ & 4 & 4 \\
\hline RSA & 2 & 2 \\
\hline GNVQ & 1 & 0 \\
\hline BTEC/BEC/TEC & 1 & 1 \\
\hline ONC & 1 & 1 \\
\hline other & 7 & 10 \\
\hline no qualification details given $^{b}$ & 57 & 58 \\
\hline course information unknown & 5 & 7 \\
\hline Total & 100 & 100 \\
\hline n weighted & 1873 & 644 \\
\hline n unweighted & 1872 & 646 \\
\hline
\end{tabular}

Column percentages: columns may total more than 100 per cent as respondents may report more than one course.

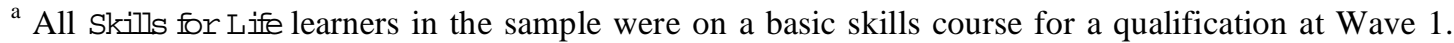
However, not all reported that they were or gave adequate details to identify whether their course was for a literacy or a numeracy qualification.

${ }^{\mathrm{b}}$ Other than whether a literacy, numeracy or Key Skills qualification

Source: Longitudinal Learners’ Survey (Wave 1, 2002/03; Wave 3 2005)

Wave 3 respondents were very similar to respondents at Wave 1 in terms of their Wave 1 courses.

Most commonly, the highest level course was at Level 2 (29 per cent) (Table 2.2). Level 1 (23 per cent) and Entry Level 1 (17 per cent) were the next most common highest qualification levels being pursued. Respondents were similar in Wave 1 and Wave 3. 
Table 2.2 Skills for Life learners: all courses, highest qualification level pursued at Wave 1

\begin{tabular}{|l|c|c|}
\multicolumn{2}{c}{} & per cent Skills for Life learners \\
\hline & Wave 1 & Wave 3 \\
\hline Entry Level 1 & 17 & 16 \\
\hline Entry Level 2 & 6 & 6 \\
\hline Entry Level 3 & 5 & 4 \\
\hline Level 1 $^{\text {a }}$ & 23 & 21 \\
\hline Level 2 & 29 & 31 \\
\hline Level 3 & 6 & 6 \\
\hline Level 4 & 2 & 2 \\
\hline Level unknown & 8 & 10 \\
\hline Course information unknown $^{\text {Total }}$ & 4 & 4 \\
\hline $\mathrm{n}$ weighted & 100 & 100 \\
\hline $\mathrm{n}$ unweighted & 1873 & 644 \\
\hline
\end{tabular}

${ }^{\text {a }}$ All GCSEs are included as Level 2.

Source: Longitudinal Learners’ Survey (Wave 1, 2002/03; Wave 3 2005)

\subsubsection{Main course, Wave 1}

Turning to respondents' main course (i.e. the one which led to them being selected for the study), three-quarters said their main course included literacy and half included maths (Table 2.3).

Table 2.3 Skills for Life learners: main course, literacy and numeracy content, Wave 1

\begin{tabular}{|l|c|c|}
\hline \multicolumn{3}{|c|}{ per cent Skills for Life lear } \\
\hline main course includes maths & Wave 1 & Wave 3 \\
\hline main course includes literacy & 50 & 52 \\
\hline & 74 & 74 \\
\hline Total & & \\
\hline $\mathrm{n}$ weighted & 100 & 100 \\
\hline $\mathrm{n}$ unweighted & 1873 & 644 \\
\hline
\end{tabular}

* fewer than $0.5 \%$

Source: Longitudinal Learners’ Survey (Wave 1, 2002/03; Wave 2, 2003/04)

The most common main course qualifications were GCSEs (24 per cent) and literacy-specific qualifications (23 per cent) (Table 2.4). City and Guilds (15 per cent) and numeracy-specific qualifications (14 per cent) were next most common.

Most commonly, main courses were at Level 2 (32 per cent) (Table 2.5). Eighteen per cent were at Level 1 and 13 per cent were mixed levels. Twenty-two per cent were below Level 1.

The motivation for doing their main course was most often for employment reasons or for one's own satisfaction (Table 2.6). Almost half were doing their main course in order to go on a further course, whilst 24 per cent were doing their course in order to be able to help their children.

Nearly all learners were doing their course part-time (93 per cent). 
Table 2.4 Skills for Life learners: main course, type of qualification pursued at Wave 1 per cent Skills for Life learners

\begin{tabular}{|l|c|c|}
\hline & Wave 1 & Wave 3 \\
\hline literacy & 23 & 24 \\
\hline numeracy & 14 & 15 \\
\hline literacy and numeracy combined & 3 & 4 \\
\hline Key Skills & 7 & 7 \\
\hline ESOL & 1 & 0 \\
\hline & & \\
\hline GCSE & 24 & 25 \\
\hline A A/S & 1 & 1 \\
\hline degree, HND, nursing, teaching & $*$ & 0 \\
\hline & & \\
\hline City and Guilds & 15 & 13 \\
\hline NVQ & 2 & 3 \\
\hline ONC & 1 & 1 \\
\hline BTEC & $*$ & 1 \\
\hline & & \\
\hline qualification not specified & 1 & 2 \\
\hline course information unknown & 5 & 4 \\
\hline & & \\
\hline Total & 100 & 100 \\
\hline n weighted & 1873 & 644 \\
\hline n unweighted & & 646 \\
\hline
\end{tabular}

* fewer than $0.5 \%$

Source: Longitudinal Learners’ Survey (Wave 1, 2002/03; Wave 2, 2003/04)

Table 2.5 Skills for Life learners: main course, qualification level pursued at Wave 1

\begin{tabular}{|l|c|c|}
\hline \multicolumn{1}{|c|}{ per cent Skills for Life learners } \\
\hline Entry Level 1 & Wave 1 & Wave 3 \\
\hline Entry Level 2 & 11 & 10 \\
\hline Entry Level 3 & 6 & 7 \\
\hline Level 1 & 5 & 5 \\
\hline Level 2 & 18 & 16 \\
\hline Level 3 & 32 & 33 \\
\hline Level 4 & 5 & 5 \\
\hline mixed levels & $*$ & 0 \\
\hline level unknown & 13 & 15 \\
\hline course information unknown & 5 & 4 \\
\hline Total & 4 & 5 \\
\hline $\mathrm{n}$ weighted & 100 & 100 \\
\hline $\mathrm{n}$ unweighted & 1873 & 644 \\
\hline
\end{tabular}

* fewer than $0.5 \%$

Source: Longitudinal Learners’ Survey (Wave 1, 2002/03; Wave 2, 2003/04) 
Table 2.6 Skills for Life learners: main course, reason for doing course at Wave 1 per cent Skills for Life learners

\begin{tabular}{|l|c|c|}
\hline & Wave 1 & Wave 3 \\
\hline work reasons & 67 & 70 \\
\hline own satisfaction & 61 & 61 \\
\hline to go on another course & 45 & 42 \\
\hline to help children more & 24 & 23 \\
\hline & & \\
\hline Total & 100 & 100 \\
\hline n weighted & 1873 & 644 \\
\hline n unweighted & 1872 & 646 \\
\hline
\end{tabular}

* fewer than $0.5 \%$

Source: Longitudinal Learners’ Survey (Wave 1, 2002/03; Wave 2, 2003/04)

\subsection{Personal and familial characteristics}

The average age of Skills for Life learners was 37. Skills for Life learners were spread across the age range, although more concentrated in the 19 to 44 age group (Table 2.7). Those aged 25-34 were slightly under-represented in the Wave 3 sample.

Table 2.7 Skills for Life learners: age at Wave 1

per cent Skills for Life learners

\begin{tabular}{|l|c|c|}
\hline & Wave 1 & Wave 3 \\
\hline $19-24$ & 22 & 22 \\
\hline $25-34$ & 25 & 19 \\
\hline $35-44$ & 29 & 32 \\
\hline $45-54$ & 15 & 17 \\
\hline 55 and over & 10 & 9 \\
\hline Total & 100 & 100 \\
\hline n weighted & 1873 & 644 \\
\hline n unweighted & 1872 & 646 \\
\hline
\end{tabular}

Source: Longitudinal Learners’ Survey (Wave 1, 2002/03; Wave 3 2005)

Women were over-represented amongst learners (57 per cent at Wave 3 and 58 per cent at Wave 1 ).

\subsubsection{Family composition and children}

Family composition may affect participation in literacy and numeracy courses. Most obviously, children may make participation in learning more difficult, whilst, at the same time, they may stimulate the desire to improve literacy and numeracy. Twenty-nine per cent of Skills for Life learners had children under 16 (Table 2.8). A high percentage had only one child (13 per cent of all learners). 
Table 2.8 Skills for Life learners: family composition

per cent Skills for Life learners

\begin{tabular}{|c|c|c|}
\hline & Wave 1 & Wave 3 \\
\hline single, no children & 54 & 53 \\
\hline partner & 35 & 35 \\
\hline lone parent & 11 & 12 \\
\hline \multicolumn{3}{|l|}{ Children under 16} \\
\hline none & 71 & 70 \\
\hline one & 13 & 13 \\
\hline two & 11 & 10 \\
\hline three or more & 6 & 7 \\
\hline Total & 100 & 100 \\
\hline n weighted & 1873 & 644 \\
\hline n unweighted & 1872 & 646 \\
\hline
\end{tabular}

Figures do not sum to 100 per cent due to rounding.

Source: Longitudinal Learners' Survey (Wave 1, 2002/03; Wave 3 2005)

Over one third of Skills for Life learners lived with a partner, whilst eleven per cent were lone parents.

\subsubsection{Ethnicity}

The majority of Skills for Life learners were white, 75 per cent (Table 2.9). Ethnic minority learners were fairly evenly spread across the other main British ethnic minority groups. Compared with Wave 1, whites were slightly over-represented amongst the Wave 3 respondents due to differential attrition rates.

Table 2.9 Skills for Life learners: ethnicity

per cent Skills for Life learners

\begin{tabular}{|l|c|c|}
\hline & Wave 1 & Wave 3 \\
\hline white & 75 & 80 \\
\hline Asian or Asian British - Pakistani or Bangladeshi & 7 & 8 \\
\hline Black or Black British - Caribbean and other & 5 & 3 \\
\hline Black or Black British - African & 4 & 3 \\
\hline Asian or Asian British - Indian & 4 & 4 \\
\hline other & 5 & 2 \\
\hline Total & 100 & 100 \\
\hline n weighted & 1873 & 644 \\
\hline n unweighted & 1872 & 646 \\
\hline
\end{tabular}

Source: Longitudinal Learners’ Survey (Wave 1, 2002/03; Wave 3 2005)

\subsubsection{First language}

English was an additional language for a relatively high percentage of Skills for Life learners, 17 per cent. However, very few were judged by the interviewer as not having good spoken English (five per cent).

\subsubsection{Health and disability}

Illness or disability was very common amongst Skills for Life learners. Fortyone per cent reported a long-standing illness or disability at Wave 1 . Thirty per cent 
(of all learners) said that their disability or health problem affected the amount or type of paid work they could do.

\subsubsection{Satisfaction with life}

How content a person is with their life is likely to affect whether that person feels the need to make changes (e.g. to participate in literacy and numeracy learning). On the other hand satisfaction with life may also indicate confidence and so one's ability and willingness to participate in literacy and numeracy training. The majority of Skills for Life learners at Wave 1 were happy with life (i.e. fairly or very happy), 85 per cent (Table 2.10). However, only one third were very happy with life.

Table 2.10 Skills for Life learners: satisfaction with life

per cent Skills for Life learners

\begin{tabular}{|l|c|c|}
\hline & Wave 1 & Wave 3 \\
\hline Very happy & 36 & 34 \\
\hline Fairly happy & 49 & 50 \\
\hline Neither happy nor unhappy & 4 & 4 \\
\hline Not very happy & 10 & 11 \\
\hline Not at all happy & 2 & 1 \\
\hline Total & 100 & 100 \\
\hline n weighted & 1873 & 644 \\
\hline n unweighted & 1872 & 646 \\
\hline
\end{tabular}

Source: Longitudinal Learners’ Survey (Wave 1, 2002/03; Wave 3 2005)

\subsection{Skills and economic activity}

This section describes the literacy and numeracy levels of Skills for Life learners, as tested at interview. The second part of the section describes qualifications and schooling. Finally, the economic activity of Skills for Life learners at Wave 1 is described.

\subsubsection{Literacy and numeracy competence}

At Wave 1, seven per cent of Skills for Life learners did not complete the literacy test and the same percentage did not complete the numeracy test. Analysis of the qualifications and courses being undertaken by these respondents suggests that their literacy and numeracy levels tended to be low.

At Wave 1 many Skills for Life learners had very low levels of literacy and numeracy competence, particularly in numeracy (Table 2.11). For literacy, nearly all were below Level 2. Thirty-six per cent of Skills for Life learners were at Level 1. Thirty-nine per cent tested at the lowest two levels. Numeracy skills tended to be lower, with Skills for Life learners concentrated at the two lowest levels of numeracy skills (78 per cent) and only nine per cent of Skills for Life learners were at Level 1 or higher. 
Table 2.11 Skills for Life learners: literacy and numeracy competence

per cent Skills for Life learners

\begin{tabular}{|c|c|c|}
\hline & Wave 1 & Wave 3 \\
\hline \multicolumn{3}{|l|}{ literacy test score } \\
\hline Entry Level 1 or below & 15 & 15 \\
\hline Entry Level 2 & 24 & 27 \\
\hline Entry Level 3 & 17 & 17 \\
\hline Level 1 & 36 & 36 \\
\hline Level 2 or above & * & 0 \\
\hline test not completed & 7 & 5 \\
\hline Total & 100 & 100 \\
\hline \multicolumn{3}{|l|}{ numeracy test score } \\
\hline Entry Level 1 or below & 39 & 40 \\
\hline Entry Level 2 & 39 & 40 \\
\hline Entry Level 3 & 7 & 5 \\
\hline Level 1 & 5 & 4 \\
\hline Level 2 or above & 4 & 6 \\
\hline test not completed & 7 & 5 \\
\hline Total & 100 & 100 \\
\hline n weighted & 1873 & 644 \\
\hline n unweighted & 1872 & 646 \\
\hline
\end{tabular}

* fewer than 0.5 per cent

Source: Longitudinal Learners’ Survey (Wave 1, 2002/03; Wave 3 2005)

Four-fifths of Skills for Life learners thought they had some problems with literacy or numeracy (Table 2.12). Problems were more often reported for literacy (69 per cent) than numeracy (53 per cent), despite the lower tested competence for numeracy.

Table 2.12 Skills for Life learners: self-assessed literacy and numeracy problems

\begin{tabular}{|l|c|c|}
\hline \multicolumn{1}{|c|}{ per cent Skills for Life learners } \\
\hline self-assessed problems: literacy & Wave 1 & Wave 3 \\
\hline self-assessed problems: numeracy & 69 & 67 \\
\hline self-assessed problems: literacy or numeracy & 53 & 53 \\
\hline & 83 & 82 \\
\hline Total & & \\
\hline n weighted & 100 & 100 \\
\hline n unweighted & 1873 & 644 \\
\hline
\end{tabular}

Source: Longitudinal Learners’ Survey (Wave 1, 2002/03; Wave 3 2005)

\subsubsection{Qualifications and schooling}

Over one-third of Skills for Life learners had no qualifications at Wave 1 (Table 2.13). Twenty-nine per cent had qualifications with their highest at Level 1, whilst 14 per cent had their highest at Level 2 and 14 per cent said they had qualifications higher than this. 
Table 2.13 Skills for Life learners: prior qualifications

\begin{tabular}{|c|c|c|}
\hline & Wave 1 & Wave 3 \\
\hline \multicolumn{3}{|l|}{ Highest qualification } \\
\hline no qualifications & 36 & 34 \\
\hline low level (unspecified) & 6 & 8 \\
\hline Entry level 1 & 1 & 1 \\
\hline level 1 or higher & 29 & 33 \\
\hline level 2 or higher & 14 & 14 \\
\hline level 3 or higher & 8 & 7 \\
\hline level 4 & 6 & 3 \\
\hline \multicolumn{3}{|l|}{ Literacy and numeracy qualifications } \\
\hline Level 2 qualification in English & 10 & 9 \\
\hline Level 2 qualification in Maths & 4 & 4 \\
\hline neither & 88 & 88 \\
\hline Total & 100 & 100 \\
\hline n weighted & 1873 & 644 \\
\hline n unweighted & 1872 & 646 \\
\hline
\end{tabular}

Source: Longitudinal Learners’ Survey (Wave 1, 2002/03; Wave 3 2005)

Almost four-fifths did not have Level 2 qualifications in either literacy or numeracy. However, ten per cent did have a literacy qualification at Level 2 and four per cent had a numeracy qualification at Level 2.

A large majority of Skills for Life learners had left school at the age of 16 or younger (Table 2.14). The remainder were equally spread between leaving before and after the age of 19.

Table 2.14 Skills for Life learners: schooling

\begin{tabular}{|c|c|c|}
\hline & Wave 1 & Wave 3 \\
\hline \multicolumn{3}{|l|}{ age left continuous full-time education } \\
\hline 16 and under & 70 & 69 \\
\hline $17-18$ & 15 & 15 \\
\hline 19 and over & 15 & 15 \\
\hline \multicolumn{3}{|l|}{ overall experience of school } \\
\hline Very positive & 22 & 20 \\
\hline Somewhat positive & 26 & 26 \\
\hline Neither positive nor negative & 4 & 6 \\
\hline Somewhat negative & 23 & 23 \\
\hline Very negative & 24 & 25 \\
\hline Total & 100 & 100 \\
\hline n weighted & 1873 & 644 \\
\hline n unweighted & 1872 & 646 \\
\hline
\end{tabular}

Source: Longitudinal Learners’ Survey (Wave 1, 2002/03; Wave 3 2005) 
One's experience at school may affect the need for literacy and numeracy training, but also willingness to take up training and to benefit from it. About half reported that their experience of school had been positive (and almost a quarter very positive), whilst almost half reported it negative (and almost a quarter very negative).

\subsubsection{Economic activity}

Economic activity and employment were low and unemployment high amongst Skills for Life learners at Wave 1. Only half of Skills for Life learners were economically active and only one third were employed (Table 2.15). Unemployment was very high amongst Skills for Life learners: 16 per cent were unemployed, giving an unemployment rate of 33 per cent.

Table 2.15 Skills for Life learners: main economic activity at Wave 1

\begin{tabular}{|c|c|c|}
\hline & Wave 1 & Wave 3 \\
\hline In full-time education & 9 & 9 \\
\hline Economically active & 49 & 53 \\
\hline Employed & 33 & 32 \\
\hline Unemployed and seeking work & 16 & 21 \\
\hline In part-time education (and not employed) & 12 & 8 \\
\hline Other & 30 & 30 \\
\hline Temporarily sick or disabled & 3 & 3 \\
\hline Permanently sick or disabled & 13 & 12 \\
\hline Looking after the home or family & 11 & 12 \\
\hline Wholly retired & 2 & 2 \\
\hline Government scheme (employment training) & 1 & 1 \\
\hline Other & 0 & 2 \\
\hline Total & 100 & 100 \\
\hline n weighted & 1873 & 644 \\
\hline n unweighted & 1872 & 646 \\
\hline
\end{tabular}

Source: Longitudinal Learners’ Survey (Wave 1, 2002/03; Wave 3 2005)

Nine per cent of Skills for Life learners were in full-time education at Wave 1. The remainder were concentrated amongst being permanently sick or disabled (13 per cent) and looking after their family (11 per cent). In addition 12 per cent classed themselves as in part-time education (and without employment).

Those who had been economically active (notably unemployed) at Wave 1 were slightly over-represented amongst Wave 3 respondents, with those declaring themselves in part-time education at Wave 1 slightly under-represented. 


\section{Impact of participation on a Ski7ls for Life course}

\subsection{The aim of the impact analysis}

The study was designed not only to enable the measurement of what had happened to the learners, but also to provide an assessment of what would have happened to them if they had not taken their literacy or numeracy courses (known as the counterfactual). Establishing the counterfactual is important, since some indicators (earnings for example) are liable to change over time as a result of increased experience and changes in the overall economic environment. Others (such as moving into paid employment) are likely to be affected by life course changes such as leaving full-time education or having a youngest child start primary school. Without a counterfactual, there is a risk of wrongly attributing movements in these indicators just to the fact of having taken a literacy or numeracy course.

The impact analysis relates only to adult learners over the age of nineteen. This was because of the impossibility of establishing a reliable comparison group who did not have a literacy or numeracy qualification and who were not involved in education or training courses. Young people in this position are a small proportion of the age group and hence difficult to find within the wider community. Moreover, as members of a very small minority they are likely to have other more complex needs which make them unreliable comparators.

\subsection{The evaluation approach}

As with all evaluations using either experimental or non-experimental methods, our aim was to obtain an unbiased estimate of the difference in outcomes between the learners and the non-learners

No matter how well designed an evaluation is, the process of comparing outcomes between groups is inevitably subject to measurement error. In the first place there will be differences in motivation and personal circumstances between those who take courses and those who do not. This characteristic in itself could affect outcomes such as employment, personal relationships and health. These outcomes for learners would probably differ from the outcomes for non-learners even in the absence of Skills for Life courses. Thus, the failure to control for this difference in an evaluation comparing participants and non-participants would lead to estimates of outcomes for those who have the greater motivation to participate to be incorrectly attributed to the courses themselves.

The standard problem with using a comparison group, as the present study has done, is that any observed differences in outcomes will partly reflect the true impact of doing a literacy or numeracy course, and partly reflect other differences between those who do courses and those who do not. This is called the standard sample selection problem: individuals who receive the treatment (in this case do a course) are generally not a random selection from the population. They have differing 
characteristics and (often) experience different circumstances. Thus, one could observe different proportions in paid employment for those who had done a course relative to those who had not even if the courses themselves had no impact because individuals who take courses had better health or motivation for example (Heckman et al 1997).

In this study the learners group was representative of learners on courses leading to qualifications in either literacy or numeracy. However, because there was limited and inconsistent information available about the size or composition of the entire population of adults with poor literacy or numeracy, any comparison group of non-learners cannot be regarded as representative of any underlying population. Rather, they are just comparators for the learners group. What this means is that the outcomes for the comparison group cannot be treated as representative of the outcomes for all non-learners with low literacy or numeracy levels. Rather, they only provide a counterfactual for the learners. Details about how the comparison sample was selected can be found in Appendix 1.

\subsubsection{Matching}

As there were some differences in characteristics between the learners and the comparison group we used propensity score matching as the method of comparing the two samples. In essence, rather than trying to match on a range of characteristics such as age, education, number of children, local labour market conditions etc, propensity score matching develops a single composite indicator, and the matching is done on the basis of that indicator. In this study the composite indicator is the probability of taking part in a Skills for Life course (Rosenbaum and Rubin 1983).

The composite indicator (propensity score) is calculated using logistic regression for each individual in both the learners and the non-learners sample based on their observed characteristics. The indicators used in the logistic regression for the propensity score matching were based on Wave 1 indicators only. The set of indicators used was the same at Wave 3 was almost exactly the same as it had been at Wave 2. The indicators were:

- age

- number and ages of children

- gender

- marital status

- ethnicity

- previous educational attainment

- literacy and numeracy levels achieved at Wave 1

- whether English is first language

- whether English is spoken at home

- self-perceived problems with literacy and numeracy

- employment status

- indicators of attitudes towards education and training

- index of employment commitment

In addition for Wave 3 the November 2002 unemployment rate for the local authority district in which the individual lived in Wave 1 was also included. This was designed to reflect the local labour market environment in which people were taking their decisions about whether or not to engage in learning. The impact of local labour 
market circumstances on the decision to take a course could come about in two ways. If the labour market had low unemployment this might increase the potential rate of return to learning, both by increasing the probability of getting a job, and by increasing pay. If the labour market had a high unemployment rate the probability of getting any job with poor literacy and numeracy would be low, which might provide an incentive to improve them. In our equation to predict taking a course the effect of the unemployment rate is negative, in other words, otherwise similar people may be more likely to take literacy and numeracy course in areas where their potential rate of return is higher.

The local authority unemployment rate was obtained from the Office for National Statistics NOMIS database of local area labour market information. It was added to the dataset by matching the individual's postcode to their local authority area using the Office for National Statistics postcode mapping dictionary. In most cases full postcodes were available, but in a small minority of cases only the first three digits of the postcodes were available. Wherever possible these were imputed to local authority areas in two ways:

- learners sampled in colleges were imputed to the local authority area where all or most of the other learners from the same college lived

- comparison group members were imputed to the local authority which covered most of the relevant postcode area

No imputation took place where there was no postcode information provided at interview, nor in the small number of cases where the postcode provided did not exist. The effect of this is to exclude 27 Wave 3 respondents from the analysis of outcomes ( 24 former learners and 3 members of the comparison group).

All those who had been interviewed as "non-learners" in that they had not been sampled at colleges, but who in fact had been doing a Skills for Life course were excluded from the propensity score matching process. There were some 280 of these, which reduced the size of the comparison sample. The reason for the exclusion is that we are trying to measure the impact of doing a Skills for Life course, and thus the comparators (those who represent what could have happened to the learners if they had not done a course) should all be people with low levels of literacy and numeracy, but who have not done a course.

The equations used for the matching are in Appendix 1. The main variables used for the matching covered demographics, level of literacy and numeracy, preexisting qualifications, age left full-time education, employment status and beliefs about the value of learning. The average estimated propensity to take part in learning for the learners was 0.651 and for the non-learners it was 0.635 . Appendix 2 sets out the mean values of the variables used to develop the propensity scores before and after matching. The matching process has a significant impact on the measured bias in many cases. Once the propensity score was calculated, members of the treatment group (i.e. learners) were matched with a non-learner based on their predicted propensity to take a course. Thus, the individual predictors (such as age, number and age of children, highest qualification) may differ between the treated individual and the matched comparison individual, but overall the combined effect of their individual predictors gives them a similar propensity to take a course. 


\subsubsection{Difference-in-differences}

The final possible source of potential bias lies in the unobserved characteristics of individuals such as motivation. To offset this a difference-indifferences approach was used. That is, the change in an indicator from one wave to another for the learners group was compared with the change in the same indicator for the comparison group. Heckman et al (1997) found that combining matching with difference-in-differences substantially reduces most of the bias introduced by using a comparison group rather than a randomly assigned experimental control group.

\subsubsection{Bootstrapping}

As a final check, the robustness of the estimates was tested by the use of bootstrapping. This is a way of testing the reliability of results, and in particular of providing an indication of the extent to which results may have been influenced by sampling error (Venables and Ripley 1999).

We have also looked at some of the transitions that took place between Wave 1 and Wave 2 to see if they are associated with particular outcomes at Wave 3. In other words we have attempted to assess whether some early outcomes might act as predictors to later outcomes. We have only reported outcomes as statistically significant if there is a 95 per cent probability that they have not occurred by chance. We also ran all our analyses with a 90 per cent confidence interval, but there were no outcomes that were significant at 90 per cent that were not also significant at 95 per cent.

\subsection{What this study is measuring}

In this study the differences between the Wave 3 and the Wave 1 outcomes for those undergoing literacy and numeracy education and training courses leading to a qualification (the learners group) were compared with the differences between the same outcomes for a sample of people with low literacy and numeracy levels who were not undertaking such courses when they were first interviewed at Wave 1 (the comparison group). The outcomes considered were related both to paid work and to personal, family and social issues. This is because improvements to literacy and numeracy can lead to improvements in the quality of life even where there is no change in employment status or income.

The analysis included only the outcomes for people who were aged eighteen or more at the time they took their original course. Young people who were aged 1618 at the time of their Wave 1 interview, many of whom were doing GCSE courses, were excluded from the analysis. This is because the pattern of transitions for young people entering adulthood and the labour market for the first time is likely to differ from the pattern for those who have already completed their initial education, many of whom will have established their own families and will have had experience of paid employment.

The Wave 1 interviews took place while the Skills for Life learners were doing their literacy or numeracy course in 2002 or 2003. The second wave of interviews took place a year later, and the third wave, which is the analysis reported here, in 2004 and 2005. Thus, for learners on one-year courses, the Wave 3 interview took place between sixteen and twenty-four months after they had completed their course. (Some learners were on longer courses.) 
Most studies of literacy and numeracy training have been small scale and qualitative. Quantitative studies of the effects of literacy and numeracy training have tended to measure change and progress amongst learners, but have not used a comparison group to group to identify whether changes would have occurred irrespective of training (e.g. Gorman and Moss, 1979; Brooks et al., 2001a, HM Inspectorate of Education 2005).

Beder (1999) reviewed a wide range of US evaluations of literacy schemes and found very few that compared learners with non-learners or that relied on anything other than self-report. International reviews of research on adult basic skills (Brooks et al., 2001b) and of the effects of improvements in adult basic skills (McIntosh, 2004, unpublished) also failed to identify studies which used comparison groups.

The present study is unusual in (a) having a large sample (b) having a comparison group and (c) having measures for both groups at different points in time. All these features are likely to increase the reliability of the findings. The steps outlined above (in particular the use of propensity score matching and difference-indifferences) are designed to eliminate, or at least substantially reduce any bias in the estimates of impact. As a consequence, where positive or negative impacts are reported, it is reasonable to attribute them to having undertaken the Skills for Life course. Qualitative studies which rely purely on self-reported perceptions of learners are unable to provide any indication as to whether an observed effect (for example an increase in earnings) is due to the learning or reflects wider developments in the economy and society more generally.

\subsection{Key findings from the present study compared with previous studies}

Although the present study uses a more rigorous methodology and has a larger sample than has traditionally been the case for studies of the impact of literacy and numeracy courses, the findings are in line with those found previously.

Beder (1999, p5) summarising the findings from 23 studies of outcomes of literacy and numeracy courses in the United States produced a list of eleven conclusions eight of which are potentially relevant to the UK context. Our findings concur with most of these.

"1. In general, it is likely that participants in adult literacy education receive gains in employment."

The present study has found small gains in employment which are not statistically significant. However, the employment gains found at Wave 3 are larger than those found at Wave 2. Moreover, two-thirds of the former Skills for Life learners who were doing another course at the time of their Wave 3 interview were not in paid employment, although half those not doing a course were in paid work. This suggests that there is still scope for improvements in employment outcomes in subsequent waves as learners complete their current courses.

"2. In general, participants in adult literacy education believe their jobs improve over time. However, there is insufficient evidence to conclude that participation in adult literacy education causes job improvement." 
The present study has found evidence that former learners are more likely than non-learners to report improvements in their satisfaction with their promotion prospects.

"3. In general, it is likely that participation in adult literacy education results in earnings gain."

Between Wave 1 and Wave 3 the earnings increase of the former Skills for Life learners was larger than that for the non-learners. We had not found an earnings effect at Wave 2.

"4. In general, adult literacy education has a positive influence on participants' continued education."

There were significant differences between the proportion of former Skills for Life learners who were doing new courses at Wave 3, compared with the proportion of members of the comparison group.

"6. Learners perceive that participation in adult literacy education improves their skills in reading, writing, and mathematics."

There were significant differences between former learners and non-learners in their perceptions of the extent to which their literacy and numeracy skills had improved over the past year.

"7. As measured by tests, the evidence is insufficient to determine whether or not participants in adult literacy education gain in basic skills."

The present study findings are similar.

“9. Participation in adult literacy has a positive impact on learners' selfimage."

At Wave 2 that learners' self-esteem had increased more than that of nonlearners, but although there was a difference at Wave 3 it was not statistically significant.

“10. according to learners' self-reports, participation in adult literacy education has a positive impact on parents' involvement in their children's education."

The proportion of the learners sample in the present study who had children was relatively small. This in turn means that the outcomes related to children are based on a very small sample, with limited statistical power. There were no statistically significant effects for reading stories to children, helping with their homework, reading, writing or using the computer. This does not mean that there were no effects, just that the effects were not detectable.

"11. Learners perceive that their personal goals are achieved through participation in adult literacy education."

Although learners were asked why they were doing their Skills for Life courses, a directly equivalent question was not asked of non-learners. This means that there were no measurable outcomes on this issue. 


\subsection{Detailed outcomes}

Appendix 4 sets out a wide range of outcomes, and indicates where they are statistically significant. The table includes the raw differences between Wave 1 and Wave 3 for the learners and the comparison group, and also the differences after propensity score matching, which tend to be smaller.

Table 3.1 provides information about a limited set of key outcomes after propensity score matching at both Wave 2 and Wave 3. These outcomes are those where an outcome was statistically significant at either wave, or where the size of the difference changed markedly between the two waves.

\subsubsection{Perceived improvements in literacy and numeracy}

When they were first interviewed respondents were not asked what they thought had happened to their literacy and numeracy over the previous year. These questions were only asked in the two follow-up waves. This means that we do not have a baseline from which to calculate differences in self-perceived literacy and numeracy improvements. We can only report the perceptions themselves. As a consequence there may be some bias in the measurement of these impacts. Nevertheless, the sizes of the effects are very large.

Respondents were asked whether they felt that their literacy and numeracy had shown (a) definite improvement, (b) some improvement or (c) no improvement in the last year. Thus, there were three possible answers for literacy and three for numeracy scored at 2, 1 and 0 respectively. Between Wave 1 and Wave 3 learners' assessments of their progress in numeracy over the previous year increased by an average of 0.83 points, while the non-learners' assessments of their progress over the previous year had increased by only 0.37 . This difference is statistically significant. At the risk of over-generalisation this means that the learners were on average reporting some improvement (i.e. they had a score just below 1 point - the value for "some improvement"), while the non-learners were reporting no improvement (i.e. they had a score close to zero, the value for "no improvement").

For literacy the perceived improvements were larger for both groups: 1.1 for the learners and 0.7 for the non-learners. Although the difference is smaller than it is for the numeracy it is still statistically significant.

Perhaps more dramatically, 56 per cent of learners and 29 per cent of nonlearners reported that their numeracy had improved over the last year. This difference is statistically significant. Among the learners group, 65 per cent of those who had taken a course involving numeracy felt that their numeracy had improved over the previous year, whereas only 40 per cent of those whose course had not involved numeracy thought that their numeracy had improved.

More than two-thirds (68 per cent) of learners but only 50 per cent of nonlearners reported that their literacy had improved. Again, these differences are statistically significant. Taking the two-thirds of learners who felt that their literacy had improved, this consisted of 42 per cent who were on a course which involved literacy and 27 per cent who were not.

Learners' strong perceptions that their literacy and numeracy have improved is in line with the findings of other studies (Beder 1999, Fingeret and Danin 1991, Fingeret 1985, Heath 1983, Fingeret and Drennon 1997, HM Inspectorate of Education 2005). In this study learners were not asked for specific examples of where 
the improvement has made a difference, but Heath (1983) found that for those with very low literacy levels, being able to write a note for a child to take to school or a list of items to remind themselves made a significant difference to their lives. 
Table 3.1 Key outcom es: $W$ ave 2 and $W$ ave 3

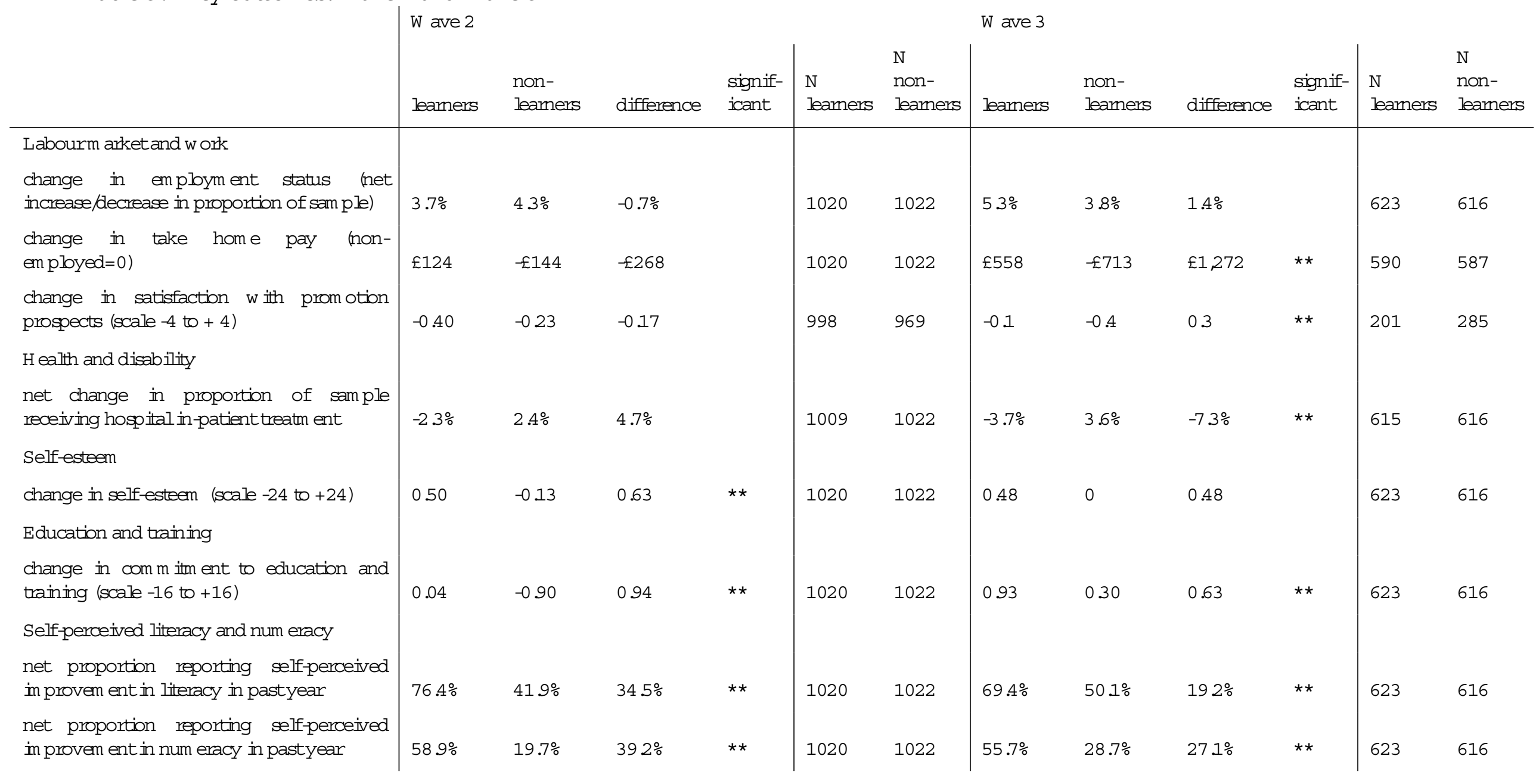


N ote: ** denotes significant at the 5\% level. 


\subsection{Labourm arketoutcom es}

Changes in several types of labourm arket outcom e w ere m easured:

Change in the proportion of the sam ple in paid em ploym ent

Change in neteamings

Change in em ploym entcom $m$ itm ent

Change in satisfaction $w$ ith prom otion prospects for those in paid em ploym ent

Paid em ploym ent

The net increase in the proportion of leamers in paid em ploym ent (i.e. the proportion gaining em ploym ent less the proportion no longer in paid em ploym ent) w as 5.3 per cent, while for the non-leamers it was 3.8 per cent. This includes selfem ployed people as w ell as em ployees.

This difference was not statistically significant, but was nevertheless an im provem ent on the $\mathrm{W}$ ave 2 position. A tW ave 2 the net increase am ong leamers $w$ as 3.7 percentand that for the non-leamers 4.3 percent. Thus, there is som e sign that the leamers' position is im proving relative to the non-leamers. M oreover, as people w ho have m oved on to take new courses (discussed below) com plete them and m ove into seeking work, it is likely that the net increase in em ploym ent w ill continue to im prove.

\section{Neteamings}

In calculating the im pact on eamings, all those not in paid em ploym ent either at $W$ ave 1 or at $W$ ave 3, w ere assigned zero eamings for that $w$ ave. A 11 those in paid em ploym ent who did not state their eamings w ere exchuded from the analysis. Thus, the overall im pacton net eamings is a com bination of the change in the proportion in paid em ploym ent (that is the proportion of zeroes), and the change in eamings am ong those w ho are em ployed.

A t $W$ ave 3 form er leamers had average take-hom e pay (inchuding income from self-em ploym ent) thatw as $£ 558$ a year higher than itw as atW ave 1, w hile nonleamers w ere eaming $£ 713$ a year less than they had been atW ave 1 . This difference was statistically significant. A though the proportion of non-leamers in paid em ploym ent had increased, their eamings had fallen. The usual reasons for low er eamings are reduced hours (a sw itch from full-tim e to part-tim e w orking perhaps) ora forced job change. People w ho becom e unem ployed typically have low er eamings in theirnew job than they did in theirold one.

Employm entcomm itm ent

Survey respondents were asked to agree or disagree $\mathrm{w}$ ith a series of five statem ents at all three w aves to elicit their com $m$ itm ent to paid em ploym ent. These were:

1. Even if I had a lotofm oney I would still work in a job

2. I am the sortofperson who needs to have a job

3. H aving a job is very im portant to $m e$

4. Ivery much want to be in a job 


\section{Even if itw ere possible form e to retire I w ould continue to work in a job}

The answ ers w ere com bined to produce an index $w$ ith values of 5 to 25 . Thus the change in com $m$ itm ent betw een waves could range from -19 to +19 . Positive values indicate becom ing m ore positive about paid em ploym ent, and negative values becom ing less positive.

Both leamers and non-leamers becam e less positive about paid em ploym ent betw een $W$ ave 1 and $W$ ave 3 (-2.6 and -3 respectively). The difference betw een the tw 0 groups w as not statistically significant. In both cases $W$ ave 3 responses w ere rather $m$ ore negative than $\mathrm{W}$ ave 2 responses (w hich show ed a difference of around $0.5)$.

\section{Prom otion prospects}

Satisfaction $w$ ith prom otion prospects $w$ as m easured on a scale of 1 to 6 . Thus, changes betw een w aves could take values of -5 to +5 . These questions w ere only asked of people who were in paid em ploym ent, so for change to be m easured a respondent had to be in paid w ork atboth $\mathrm{W}$ ave 1 and $\mathrm{W}$ ave 3 .

Form er leamers had little change in their satisfaction $w$ ith their prom otion prospects betw een $\mathrm{W}$ ave 1 and $\mathrm{W}$ ave $3(-0.1)$ w hile non-leamers had a larger fall ($0.4)$. This difference is statistically significant. A tW ave 2 the form er leamers had had a fall of -0.4 and the non-leamers a fall of -02 , but the difference w as not statistically significant. Thus, leamers had show $\mathrm{n}$ an im provem ent in their satisfaction $\mathrm{w}$ ith their prom otion prospects betw een $W$ aves 2 and 3, w hile com parison group $m$ em bers had show $n$ a decline.

A $m$ ong form er leamers 38 per cent reported higher levels of satisfaction $w$ ith their prom otion prospects at $W$ ave 3 com pared $w$ ith 29 per cent of non-leamers. Further, 35 per cent of leamers reported low er levels of satisfaction with their prom otion prospects at $W$ ave 3 , com pared $w$ ith 44 percentof non-leamers.

O ther aspects of work

There were only small differences between the form er leamers and the com parison group in term s of changes in their satisfaction w ith their job security or their pay. The differences w ere not statistically significant. There w ere no statistically significant differences in these indicators atW ave 2 either.

\subsection{O utofwork benefits}

A tboth $\mathrm{W}$ ave 1 and $\mathrm{W}$ ave 3 respondents $\mathrm{w}$ ere asked about receipt of out-ofw ouk benefits by the respondent or their partner. The benefits inchuded in the analysis w ere Jobseekers A llow ance, Incapacity B enefit, Incom e Support, W idow 's Pension, Statutory Sick Pay, Invalid Care A llow ance, retirem ent pension, Severe D isablem ent A llow ance and Carer's Allow ance.

A m ong the leamers there w as a 3.8 percentage point fall in the proportion of the sam ple receiving out-of-w ork benefits at $W$ ave 3 com pared $w$ ith the proportion at $\mathrm{W}$ ave 1 , while am ong the non-leamers the fall w as 0.4 percentage points. H ow ever, the difference w as not statistically significant.

\footnotetext{
${ }^{3} \mathrm{~W}$ e recognise that som e of these benefits $\mathrm{m}$ ay be payable $\mathrm{w}$ hen people are in paid w olk, but in practice the overw helm ing $m$ ajority of recipients are outof w ork.
} 


\subsubsection{H ealth and disability outcom es}

There w as a range of health outcom es inchuded in the analysis, but for only one of them w as there a large or statistically significant difference betw een the form er leamers and the non-leamers. H ow ever, in m ost cases the outcom es for the leamers w ere better than the outcom es for the non-leamers.

The one statistically significant difference $w$ as that there $w$ as a difference in the incidence of hospital in-patient treatm ent. There w as a net fall of 3.7 percentage points in the proportion of form er leamers receiving hospital in-patient treatm ent at $\mathrm{W}$ ave 3 when com pared $\mathrm{w}$ ith $\mathrm{W}$ ave 1, whereas there $\mathrm{w}$ as an increase of 3.6 percentage points am ong the non-leamers. This difference w as statistically significant. A tW ave 2 there had been a sm aller fall in the proportion having in-patient treatm ent (2 3 percentage points) and a sm aller increase am ong the non-leamers (2.4 percentage points) . That difference w as not statistically significant.

The other health outcom es review ed w ere:

o The proportion of both leamers and non-leamers w ho reported w orse less the proportion w ho reported im proved health

0 The change in the average value of the health index betw een $\mathrm{W}$ ave 1 and $\mathrm{W}$ ave 3

o Change in long-standing iᄁhess ordisability

o G P attendances

o H ospitaloutpatient appointm ents

o $\quad \mathrm{N}$ ights spentas a hospital in-patient

\subsubsection{Activities w ith children}

Only a m inority of both leamers and non-leamers lived in households w here there w ere children under sixteen (and even few er w ere living $w$ ith their ow $n$ or their partner's children rather than w ith younger siblings or other relatives). B ecause the questions relating to activities with children w ere only asked of people who had children living in the household, the analysis had to be restricted to people w ho had children in their household in both $\mathrm{W}$ ave 1 and $\mathrm{W}$ ave 3 . This m eans that the statistical power of any of the comparisons involving children is very lim ited, and the differences between the two groups would need to be large to be statistically significant.

Thus, although respondents were asked about reading stories to children, helping them $w$ ith hom ew ork, w ith reading, w ith $w$ riting and $w$ ith using the com puter, the $\mathrm{sm}$ all num ber of respondents $m$ eant that in no case $w$ ere the differences betw een the tw o groups statistically significant.

The com bination of $\mathrm{sm}$ all sam ple num bers and an ageing cohort of children in the household $\mathrm{w}$ ill probably $\mathrm{m}$ ake it difficult to detect results in this area in future w aves of the study, although it has been found to be im portant in other studies. The US evidence review ed by Beder (1999) found that being better able to help children w as one of the m ore frequently observed outcom es of literacy and num eracy training for adults. HM Inspectorate of Education (2005) which involved interview s w ith $m$ ore than 150 literacy and num eracy leamers in Scotland also found thatbeing able to help children w as cited by $m$ any as an im portantoutcom e for them . 


\subsubsection{Self-esteem and life satisfaction}

Previous studies have consistently found that those who take literacy or num eracy courses have an im proved self-im age (Beder 1999). A tW ave 2 we found statistically significant differences in self-esteem betw een the leamers and the nonleamers. H ow ever, the difference atW ave $3 \mathrm{w}$ as not significant.

Selfesteem was measured in this study using the shortened version of the Rosenberg self-esteem scale (Rosenberg 1965) developed by Sm ith et al. (2001). Respondents w ere asked to agree or disagree $w$ ith a series of six questions, each of which had five possible answ ers. In each case high self-esteem w as scored $w$ ith a value of 5 and low self-esteem $w$ ith a value of 1 . Som etim es this reflected agreem ent $\mathrm{w}$ ith a statem ent and som etim es disagreem ent. The six questions w ere:

1. I like m yself

2. Ioften w ish I was som eone else

3. I am able to do things well

4. Idon't think much ofm yself

5. There are som e good things aboutme

6. There are lots of things aboutm yself I w ould like to change

Form er Skills for Life leamers show ed a sm all increase in self-esteem betw een $\mathrm{W}$ ave 1 and $\mathrm{W}$ ave 3 (0.49 on a scale of -24 to +24$)$. This $w$ as identical to the increase found at $W$ ave $2 . N$ on-leamers show ed no change in their self-esteem betw een $W$ ave 1 and $W$ ave 3 . B etw een $W$ ave 1 and $W$ ave 2 they had show $n$ a sm all decline $(-0.13)$. Both the sam ple size and the difference w ere larger atW ave 2 , leading to an outcom $e$ that $w$ as statistically significant. How ever, at $W$ ave 3 the smaller difference (accounted for by the unchanged self-esteem in the com parison group) and the sm aller sam ple size m eant that the difference w as not statistically significant.

Satisfaction w ith life w as m easured on a scale of 1 to 5, so the change betw een $\mathrm{W}$ ave 1 and $\mathrm{W}$ ave $3 \mathrm{w}$ as $\mathrm{m}$ easured on a scale of -4 to +4 . B oth the leamers and the non-leamers show ed an increase of less than 0.1 , and the difference betw een the two groups w as not statistically significant.

\subsubsection{Education and training}

Com m itm ent to education and training

There were large and statistically significant differences in the change in com $m$ itm ent to education and training betw een the form er Skills for Life leamers and the com parison group.

Com m itm ent to education and training w as m easured by four questions each $\mathrm{w}$ ith five possible answ ers. Thus, the value of the index ateach $\mathrm{w}$ ave varied from 4 to 20 ( $w$ ith 20 being the $m$ axim um levelof com $m$ itm ent), and the change betw een w aves could vary from -16 to +16 .

Respondents were asked for the extent to which they agreed $w$ ith the follow ing fourstatem ents:

1. You are m ore likely to geta better job ifyou do som e leaming 


\section{Leaming new things m akes you m ore confident}

\section{To geta job who you know is m ore im portant than whatyou know}

\section{G etting qualifications takes too m uch effort}

B etw een $W$ ave 1 and $W$ ave 3 the form erSkills for Life leamers had an average increase in the value of their index of 0.93 , while the com parison group $m$ em bers had an increase of 0.3 . This difference is statistically significant.

A tW ave 2 there w as also a statistically significant difference betw een the tw o groups, but this w as $m$ ade up of a very $\mathrm{sm}$ all im provem ent in com $m$ itm entam ong the leamers (.04) and a decline in com $m$ itm entam ong the non-leamers of 0.9 . Thus, both leamers and non-leamers have both becom e m ore positive tow ards education and training since $W$ ave 2.

\section{D oing a new course}

A nother significant difference betw een the tw o groups $w$ as the extent to w hich they had gone on to take a new education or training course. A t the tim e of the $W$ ave 3 interview, nearly half (48 per cent) of form er Skills for Life leamers w ere taking a new education or training course, while only 10 per cent of com parison group $\mathrm{m}$ em bers were. (A m ore detailed discussion of both new and continuing courses for Skills for Life leamers can be found in Section 422 .)

This finding is particularly im portant in that it supports the hypothesis that the $m$ ain value of im proving literacy and num eracy skills for adults as w ell as for young people is that it opens the w ay to leaming skills w hich are directly relevant to w olk, and to life more generally. Literacy and num eracy are building blocks to the developm ent of skills relevant to the w orkplace rather than necessarily leading to a direct increase in em ployability. W hile they are useful in them selves, the real value of literacy and num eracy courses lies in enabling people to progress to further education and training and to develop skills that more directly influence their em ploym ent and eamings prospects. (See for exam ple, Boe 1997, Bonjour and Sm eaton 2003, Bynneretal2001).

It is also consistent $w$ ith intemational research. Beder (1999) reported that participation in adult literacy and num eracy training led to greater participation in further education training for US adults. It also led to an increase in acquiring the GED qualification (the adult equivalent of high school graduation). Rahm ani et al (2002) found thatA ustralians w ho com pleted basic skills training w ere m ore likely to be continuing in education than those w ho did notstartor did notcom plete the course.

The fact that half the leamers are using their literacy and num eracy courses as a stepping stone to other leaming is likely to be an im portant explanation for the sm all (and statistically insignificant) scale of the em ploym ent effects found at W ave 3, which took place two years after respondents were first interview ed. A s leamers com plete their new courses and start to look for and find paid w ork the proportion of the sam ple w ho are em ployed is likely to increase further. A m ong form er Skills for Life leamers, two-thirds of the people taking courses are not currently em ployed, com pared $w$ ith 56 percent of the people w ho are not taking courses. 


\subsection{A ssociations betw een $W$ ave 2 outcom es and $W$ ave 3 outcom es}

G iven the suggestion from other studies that the final outcom es from undertaking courses to im prove literacy and num eracy often take som e tim e to em erge, one potential benefit of a longitudinal study design is that it enables trajectories to be tracked, and an assessm entm ade of the extent to w hich som e of the outcom es observed soon after the com pletion of the Skills for Life course atW ave 2 $\mathrm{m}$ ightbe predictors of outcom es observed at later stages in the leamers' lives. This is potentially useful for practitioners and funders since they are only likely to be in a position to m onitor short-term outcom es.

The analysis reported here exam ined the variables where there were statistically significant differences betw een the form er leamers and the com parison group atW ave 2 to see w hether they w ere associated $w$ ith outcom es atW ave 3.

The statistically significantoutcom es atW ave 2 thatw ere analysed w ere:

0 self-esteem

o attitudes to education and training

0 em ploym entcom $m$ itm ent

0 self-perceived im provem ent in literacy

0 self-perceived im provem ent in num eracy.

W e looked at the comelation betw een each of these $W$ ave 2 outcom es and the follow ing $W$ ave 3 outcom es:
o change in em ploym ent status
0 change in eamings
0 taking an education or training course.

In alm ost all cases there w as no relationship betw een the $\mathrm{W}$ ave 2 outcom es and the $\mathrm{W}$ ave 3 outcom es. Thus, there is little that can be conchuded at this stage as to w hether early outcom es $\mathrm{m}$ ightbe predictors of later outcom es. O f the fifteen possible relationships, only tw o w ere statistically significant.

\subsubsection{A ttitudes to education and training and subsequentparticipation in education and training courses}

Form er Skills for Life leamers were m ore likely than non-leamers to have increased theircom $\mathrm{m}$ itm ent to education and training betw een $\mathrm{W}$ ave 1 and $\mathrm{W}$ ave 2 of the study. H ow ever, w ithin the form er leamers group, those w ho had increased their comm itm ent to education and training between $\mathrm{W}$ ave 1 and $\mathrm{W}$ ave 2 were significantly m ore likely to be taking an education or training course at W ave 3 than those whose com $\mathrm{m}$ itm ent had not increased. A $\mathrm{m}$ ong those whose com $\mathrm{m}$ itm ent w as higher at $W$ ave 2, 54 per cent w ere taking a course at $W$ ave 3 . A m ong those w hose com $m$ itm enthad not increased atW ave 2, 45 percentw ere taking a course atW ave 3 . This difference is statistically significant.

\subsection{Self-perceived im provem ent in num eracy and literacy and eamings}

Form er Skills for Life leamers who perceived that their num eracy had im proved betw een $\mathrm{W}$ ave 1 and $\mathrm{W}$ ave 2 had significantly larger increases in eamings betw een $W$ ave 1 and $W$ ave 3 than those w hose num eracy had not im proved. They had 
an average increase in eamings of $£ 3567$ a year. Those who thought at $W$ ave 2 that theirnum eracy had declined had an increase of $£ 232$ and those $w$ ho thought there $w$ as no difference in theirnum eracy had a fallof £232. (The difference betw een these tw 0 groups is not statistically significant.)

There w as no association betw een self-perceived im provem ent in literacy at $\mathrm{W}$ ave 2 and the increase in eamings betw een $\mathrm{W}$ ave 1 and $\mathrm{W}$ ave 3.

A though we have not identified $m$ any predictors of future positive outcom es, we will continue to analyse such associations at the next $\mathrm{W}$ ave because of the practical value of early indicators as feedback to practitioners and funders.

\subsection{O verallconchusions of the im pact study}

Skills for Life courses do have an im pact on self-esteem, on eamings, on em ploym entand on health, although at this early stage $m$ any of the im pacts are sm all. How ever, there are indications that som e of these outcom es (em ploym ent in particular) are likely to increase in the future.

An im portant im pact relates to lifelong leaming. A dults $w$ ith poor basic skills have often not had good experiences at school, and it is know n that those $\mathrm{w}$ ith poor school experiences are difficult to attractback into leaming as adults. Y et those who had taken literacy or num eracy courses have becom e m ore positive in their attitudes tow ards the value of education and training, and a large proportion have gone on to take new courses ( $m$ any of them full-tim e).

This active engagem ent $w$ ith full-tim e education on the part of the form er Skills for Life leamers $m$ eans that although their em ploym ent rates have been higher (and the differences w ith the com parison group larger) at each successive $w$ ave of the study, the im pact is not statistically significant. It is, how ever, reasonable to expect that some of those cumently taking education and training courses $\mathrm{w}$ ill $\mathrm{m}$ ove into em ploym ent over the next few years. 


\subsection{Introduction}

The im pact analysis show ed that participation on a Skills for Life course increased subsequent participation in leaming. It also led to a greater com $m$ itm ent to education and training. In this chapter we exam ine in more detail Skills for Life leamers' subsequenteducation and training, describing the type of courses undertaken and the factors w hich affect subsequent leaming.

In Section 42 , the general pattem of participation in education and training one and tw o years after initial interview is described. This show s that m any Skills for Life leamers continue theirW ave $1 \mathrm{Skills}$ for Life course into a second and a third year but, also, thatm any start new courses. It also show s that starting a new course w hilst continuing courses from the previous year is com m on. Specifically:

72 per cent of Skills for Life leamers were still in education and training in $Y$ ear 2 ;

57 per cent of Skills for Life leamers were still in education and training in $Y$ ear 3 ;

64 per cent had started new courses $w$ ithin tw o years (47 per cent in Y ear 2 and 40 percent in $Y$ ear 3 ).

The pattem of further study was com plex, w ith m any starting new courses whilstcontinuing existing courses.

The rest of the chapter then focuses on new courses. Section 4.3 describes the characteristics of new courses pursued: their subject and level:

34 percentof Skills for Life leamers had started a new course at Level 2 or above in either $Y$ ear 2 or $Y$ ear 3 ;

alm ost half (48 per cent) of Skills for Life leamers had started a new vocational course in either $Y$ ear 2 or 3 ;

43 percenthad started a new basic skills course, w ith the percentage of new starts for the later declining across the years;

17 per cent of Skills for Life leamers had started a new academ ic course;

NV Q S, C ity and G uilds and IT qualifications w ere m ostcom $m$ on.

These new courses $m$ ay be at the sam e, a higher or a low er level than those pursued at W ave 1. O ur interest was particularly on progression, so Section 4.4 describes the pattem of progression and the types of progression courses (i.e. courses at a higher level than atW ave 1): 
30 per cent of Skills for Life leamers had started a new, higher-level course in either $Y$ ear 2 or 3 ; progression $w$ as $m$ ore com $m$ on in $Y$ ear 2 than $Y$ ear 3;

by Y ear 3, 24 percent of Skills for Life leamers had m oved to a higherlevel course at Level 2 or higher (including 15 per cent to Level 3 or higher) ;

Progression w as m ost com m on for those w hose highest level of study in Y ear $1 \mathrm{w}$ as Level 1, butprogression w as high from all levels.

Finally, Section 4.5 exam ines the factors which affect starting new courses and progression. This found that there are relatively few personal and educational characteristics which are associated w ith new course participation and progression. This suggests that Skills for Life courses can act as a route to leaming for a w ide range of people, and that there appear to be few factors, apart from health, which act as a bamier to future leaming.

\section{Continuation in education and training}

This section provides an overview of Skills for Life leamers participation in education and training one and tw o years after their first interview on the study. Of particular interest is take up of new courses, especially of courses at a higher level than previously (i.e. progression). How ever, new course start-up m ay be delayed when $\mathrm{W}$ ave 1 course(s) continue into second or subsequent year. In which case focussing on new course start-up w ill underestim ate the participation in education and training. Therefore, this section starts by describing overall participation in education and training, whether on a new course or a continuing course. It then describes how continuing courses, new starts and new starts at a higher level (i.e. progression) interrelate.

\section{Participation in education and training}

Participation in education and training for Skills for Life leamers in Y ears 2 and $3 \mathrm{w}$ as very high (Figure 4.1).

A Im ost three-quarters (72 per cent) w ere on a course at $Y$ ear 2 and 57 percentw ere on a course atY ear 3 .

$\mathrm{H}$ alf of Skills for Life leamers participated in education and training at both $Y$ ear 2 and $Y$ ear 3 . A bout one fifth participated in $Y$ ear 2, but then stopped atY ear 3.

Re-entry into education and training by those who were not doing a course in $Y$ ear $2 \mathrm{w}$ as not uncom $\mathrm{m}$ on: one quarter of this group (seven percent of all leamers) retumed to leaming in $Y$ ear 3 . 
Figure 4.1 Participation in courses, Y ears 1 to 3

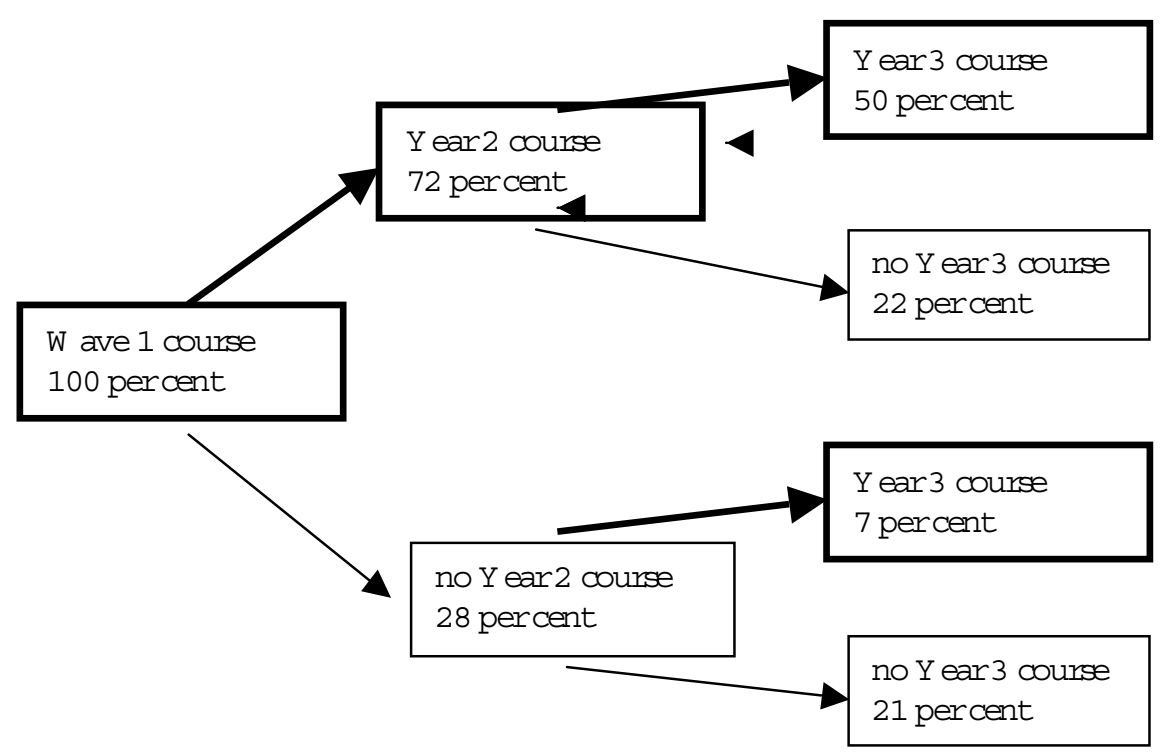

\section{N ew courses and course continuation}

In part, the high level of course participation w as due to leamers continuing the sam e courses from one year to the next. H ow ever, new course starts w ere also high (see Figure 42 and Figure 4.3 ):

at Y ear 2, alm ost half (48 per cent) of Skills for Life leamers were continuing a course from $Y$ ear $1, w$ ith 40 per cent continuing their $\mathrm{m}$ ain Skills for Life course and 22 per cent continuing another $Y$ ear 1 course (and 15 percentdoing both);

atY ear 3, nearly one third (32 per cent) of Skitls for Life leamers w ere continuing a course from $Y$ ear 2 , w ith 21 per cent still on their $m$ ain Skills for Life course (from $\mathrm{W}$ ave 1 ) and 20 percentcontinuing another Y ear 2 course (and nine percentdoing both);

by $Y$ ear 2,47 percenthad started a new course since $Y$ ear 1 ;

by Y ear 3, 40 percenthad started a new course since $Y$ ear 2 ;

over both years, 64 per cent of Skills for Life leamers had started new courses (inchuding 23 per cent who had started new courses in both Y ears 2 and 3 ). 
Figure 4.2 New and continuing courses, Year 2

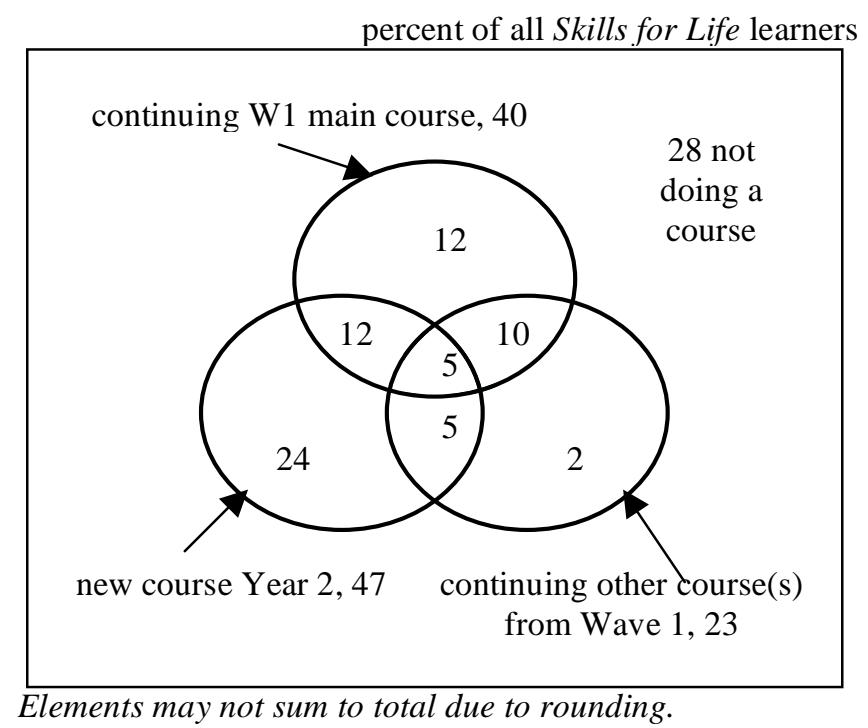

Figure 4.3 New and continuing courses, Year 3

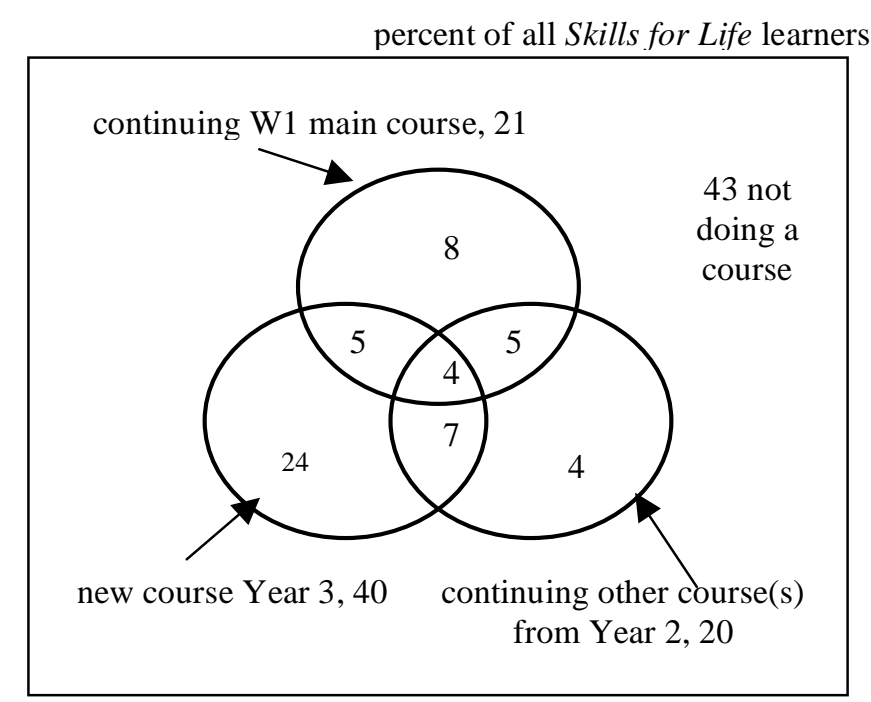

Elements may not sum to total due to rounding.

\subsubsection{Combining new courses and continuing courses}

We had expected Skills for Life learners to complete one course before starting another. However, as the Figure 4.2 and Figure 4.3 show, many Skills for Life learners started a new course whilst continuing a previous course:

by Year 2, 22 per cent of Skills for Life learners had started a new course, whilst continuing a course from Year 1;

by Year 3, 16 per cent of Skills for Life learners had started a new course, whilst continuing a course from Year 2. 
Com parison of those who were continuing a previous course and those who w ere not (Table 4.1 ) show s that:

those continuing courses at Y ear 2 w ere just as likely to start a new course as those w ho w ere notcontinuing a course. (Forty-nine per cent of continuers started a new course, com pared w ith 46 per cent of those notcontinuing a course)

atY ear 3, those continuing a course from the previous year w ere m ore likely to start a new course than those who were not continuing a course (45 percentand 38 percentrespectively).

Table $4.1 \mathrm{~N}$ ew and higher-level courses by continuation of Y ear 1 courses

\begin{tabular}{|c|c|c|c|c|c|c|}
\hline & $\begin{array}{c}\text { new } \\
\text { course }\end{array}$ & $\begin{array}{c}\text { no new } \\
\text { course }\end{array}$ & total $I^{2}$ & $\begin{array}{l}\text { doing a new } \\
\text { higher-level } \\
\text { course }\end{array}$ & $\begin{array}{l}\text { notdoing a } \\
\text { new higher- } \\
\text { levelcourse }\end{array}$ & total $I^{2}$ \\
\hline \multicolumn{7}{|l|}{ Y ear2 } \\
\hline continuing a Y ear 1 course & 49 & 51 & 100 & 22 & 78 & 100 \\
\hline notcontinuing a $Y$ ear 1 course & 46 & 54 & 100 & 22 & 78 & 100 \\
\hline Total & 47 & 53 & 100 & 22 & 78 & 100 \\
\hline \multicolumn{7}{|l|}{ Y ear3 } \\
\hline continuing a $Y$ ear 2 course ${ }^{b}$ & 45 & 55 & 100 & 15 & 85 & 100 \\
\hline notcontinuing a $Y$ ear 2 course ${ }^{b}$ & 38 & 62 & 100 & 16 & 84 & 100 \\
\hline Total & 40 & 60 & 100 & 16 & 84 & 100 \\
\hline
\end{tabular}

${ }^{a} \mathrm{~B}$ ase refers to all respondents at the relevantyear.

b Inchudes $Y$ ear 1 courses continued through $Y$ ear 2 and into $Y$ ear 3

Progression (i.e. starting a course at a higher level) was just as comm on am ongst those continuing courses betw een years as those not.

The role of continuation and other factors on new course starts and progression is exam ined in detailusing regression analysis in Section 4.5 .

\section{N ew course characteristics, Y ears 2 and 3}

A s Skills for Life leamers m oved to new courses, the types of courses taken changed. N otonly did they progress to higher levels, but they m oved aw ay from basic skitls courses to vocational and academ ic courses. These changes are described in this section.

\subsubsection{Changes in the characteristics of courses}

There w as a m ajor change in the types of courses started in Y ears 2 and 3 com pared $w$ ith $Y$ ear 1 courses, $w$ ith a m ovem ent tow ards vocational courses and aw ay from basic skills (Table 42 ):

the prevalence of basic skills courses declined relative to academ ic and, particularly, to vocational courses;

the move aw ay from basic skiths courses and tow ards vocational courses grew over tim $e$, from $Y$ ear 2 to $Y$ ear 3 : 
o vocational courses grew from 44 per cent ( $Y$ ear 1 ), to 65 per cent of new starts in $Y$ ear 2, to 73 per cent of new starts in Y ear 3;

0 basic skills courses declined from 89 per cent in Y ear 1, to 63 per cent of new starts in $Y$ ear 2 to 53 per cent of new starts in Y ear 3 .

the prevalence of academ ic courses declined slightly .

The shift from basic skills courses tow ards vocational courses suggests that, as Skills for Life leamers im proved their basic skills m any then m oved on to education and training thatw as m ore directly vocational.

Exam ining new course subjects in m ore detail, show s that:

am ongst academ ic courses, few er took new G CSE courses in Y ears 2 and 3 than had atW ave 1, whilsthigher-level courses increased; and

am ongst vocational qualifications, the $m$ ain relative changes w ere an increase in the percentages doing $\mathrm{NVQ}$ s and 'other' (generally lowlevel) qualifications.

The highest level at w hich Skills for Life leamers w ere studying show ed som e tendency to rise (Table 4.3):

there w as a m arked increase in the percentage studying up to Level 3, rising from six percent in $Y$ ear 1 to 18 percent in both $Y$ ears 2 and 3;

there w as som e decline in Entry Level courses, which w as m arked at Entry Level1;

how ever, there w as a decline in Level 2 courses, from 31 per cent in $Y$ ear 1 , to 26 percent in $Y$ ear 2 and 23 percent in $Y$ ear 3 . 
Table $42 \mathrm{~N}$ ew course starters: new course qualification, Y ears 2 and 3

\begin{tabular}{|c|c|c|c|c|}
\hline & \multicolumn{4}{|c|}{ \% Skills for Life leamers starting a new course } \\
\hline & $\begin{array}{l}\text { W ave } 1 \\
\text { courses }\end{array}$ & $\begin{array}{l}\text { Y ear2 new } \\
\text { courses }\end{array}$ & $\begin{array}{l}\text { Y ear3 new } \\
\text { courses }\end{array}$ & $\begin{array}{c}\text { N ew courses, } \\
\text { Y ears } 2 \\
\text { and/or } 3\end{array}$ \\
\hline Basic skills & 89 & 63 & 53 & 67 \\
\hline literacy & 70 & 41 & 33 & 43 \\
\hline num eracy & 51 & 36 & 25 & 38 \\
\hline com bined literacy and num eracy & 4 & 0 & 0 & \\
\hline Key Skills & 17 & 21 & 20 & 27 \\
\hline ESOL L & 1 & 4 & 0 & 3 \\
\hline A cadem ic qualifications & 29 & 23 & 23 & 26 \\
\hline GCSE & 28 & 16 & 12 & 17 \\
\hline A orA S Levels, A ccess course & 2 & 7 & 7 & 8 \\
\hline V ocationalqualifications & 44 & 65 & 73 & 75 \\
\hline NVQ & 4 & 15 & 21 & 21 \\
\hline GNVQ & 0 & 3 & 2 & 3 \\
\hline C ity and G uilds & 17 & 17 & 10 & 17 \\
\hline RSA & 3 & 2 & 1 & 2 \\
\hline BTEC & 1 & 3 & 5 & 4 \\
\hline $\mathrm{ONC}$ & 1 & 1 & 1 & 1 \\
\hline CLA IT/other IT & 11 & 12 & 11 & 16 \\
\hline other & 15 & 27 & 38 & 38 \\
\hline $\begin{array}{l}\text { Total (Skills for Life leamers } \\
\text { starting a new course) }\end{array}$ & 100 & 100 & 100 & 100 \\
\hline n w eighted & 598 & 305 & 257 & 412 \\
\hline
\end{tabular}

B ase: Skills for Life leamers starting a new course

Table 4.3 N ew course starters: highest new course qualification level Y ears 2 and 3

\begin{tabular}{|l|c|c|c|c|}
\hline \multirow{2}{*}{$\begin{array}{l}\text { H ighestnew course qualification } \\
\text { level }\end{array}$} & \multicolumn{3}{|c|}{ \% Skills for Life leamers starting a new course } \\
\cline { 2 - 5 } low level/levelunknown & 16 & $\begin{array}{c}\text { Y ear2 new } \\
\text { courses }\end{array}$ & $\begin{array}{c}\text { Y ear3 new } \\
\text { courses }\end{array}$ & $\begin{array}{c}\text { N ew courses, } \\
\text { Y ears 2 and/or3 }\end{array}$ \\
\hline Entry level1 & 10 & 19 & 23 & 16 \\
\hline Entry level2 & 6 & 3 & 2 & 2 \\
\hline Entry level3 & 4 & 2 & 5 & 5 \\
\hline level1 & 21 & 27 & 21 & 2 \\
\hline level2 & 31 & 26 & 23 & 23 \\
\hline level3 & 6 & 18 & 18 & 20 \\
\hline level4 & 2 & 3 & 6 & 5 \\
\hline no detailsgiven & 4 & & & \\
\hline total & 100 & 100 & 100 & 100 \\
\hline n w eighted & 644 & 305 & 257 & 412 \\
\hline
\end{tabular}

Base: Skills for Life leamers starting a new course 


\section{Participation in new courses}

The previous section (4 3.1 ) exam ined how the type of new courses Skitls for Life leamers started changed over the three years. This section describes the extent to which Skills for Life leamers took up these new courses. (The difference in percentages betw een the tw o sections is because this section refers to the percentage of all Skills for Life leamers. The previous section exam ined the percentage of new course starts.)

The shift in new starts, from basic skills courses to vocational courses w as described in the previous section, along $\mathrm{w}$ ith the relative stability in the percentage of new academ ic courses. H ow ever, given the difference in percentage of Skills for Life leamers taking basic skills courses, vocational courses and academ ic courses in Y ear 1, the pattem of Skills for Life leamers on the different type of courses in later years w as as follow s (Table 4.4):

a substantialm inority of Skills for Life leamers started new basic skiths courses in Y ears 2 and 3:30 per cent of Skills for Life leamers started a new basic skills course in Y ear 2 and 21 percent started one in Y ear 3 ;

the percentage of Skills for Life leamers stanting a new vocational course equalled those starting new basic skitls courses in Y ear 2 and overtook it in Y ear 3 (by Y ear 329 percentvocational and 21 percent basic ski7ls);

the percentage of Skills for Life leamers starting new academ ic courses w as low : 11 percent in $Y$ ear 2 and nine percent in $Y$ ear 3 ;

together, overboth $Y$ ear 2 and $Y$ ear 3 :

o 48 per cent of Skills for Life leamers started a new vocational course;

o 43 percent started a new basic ski7ls course; and

o 17 percent started a new academ ic course.

The highest-level, new course was at Level 1 and above for a substantial $m$ inority of Skills for Life leamers. Few had started new courses atEntry Levels only:

new course at Level 2 and above: 22 per cent (Y ear 2), 19 per cent (Y ear 3) and 34 percentoverboth years;

new course at Level 1: 13 per cent at (Y ear 2), eight per cent (Y ear 3) and 15 percentover both years; and

new course atEntry Level: three per cent (Y ear 2), fourper cent (Y ear 3) and five percentoverboth years 
Table $4.4 \mathrm{~N}$ ew course participation, new course qualification, Y ears 2 and 3

\begin{tabular}{|c|c|c|c|c|}
\hline & \multicolumn{4}{|c|}{ \% Skills for Life leamers } \\
\hline & $\begin{array}{l}\text { W ave } 1 \\
\text { courses }\end{array}$ & $\begin{array}{c}\text { Y ear2 new } \\
\text { courses }\end{array}$ & $\begin{array}{c}\text { Y ear3 new } \\
\text { courses }\end{array}$ & $\begin{array}{c}\text { N ew courses, } \\
\text { Y ears } 2 \\
\text { and/or } 3\end{array}$ \\
\hline Basic skills & 83 & 30 & 21 & 43 \\
\hline literacy & 65 & 19 & 13 & 28 \\
\hline num eracy & 47 & 17 & 10 & 24 \\
\hline com bined literacy and num eracy & 4 & 0 & 0 & 0 \\
\hline Key Ski7ls & 16 & 10 & 8 & 17 \\
\hline ESOL L & 1 & 2 & 0 & 2 \\
\hline A cadem ic qualifications & 27 & 11 & 9 & 17 \\
\hline GCSE & 26 & 8 & 5 & 11 \\
\hline A orA S Levels, A ccess course & 2 & 3 & 3 & 5 \\
\hline $\begin{array}{l}\text { degree, } \mathrm{HND}, \mathrm{HNC} \text {, nursing, } \\
\text { teaching }\end{array}$ & 2 & 2 & 3 & 3 \\
\hline Vocationalqualifications & 41 & 31 & 29 & 48 \\
\hline $\mathrm{NVQ}$ & 4 & 7 & 8 & 14 \\
\hline GNVQ & 0 & 2 & 1 & 2 \\
\hline C ity and G uilds & 16 & 8 & 4 & 11 \\
\hline RSA & 2 & 1 & 0 & 1 \\
\hline $\mathrm{BTEC}$ & 1 & 2 & 2 & 3 \\
\hline $\mathrm{ONC}$ & 1 & 0 & 1 & 1 \\
\hline CLA IT/other IT & 10 & 6 & 4 & 10 \\
\hline other & 14 & 13 & 15 & 24 \\
\hline no course/hew course & 7 & 53 & 60 & 64 \\
\hline Total & 100 & 100 & 100 & 100 \\
\hline n w eighted & 644 & 644 & 644 & 644 \\
\hline
\end{tabular}

B ase: all Skills for Life leamers

Table $4.5 \mathrm{~N}$ ew course participation, highestnew course qualification, Y ears 2 and 3

\begin{tabular}{|c|c|c|c|c|}
\hline \multirow[b]{2}{*}{$\begin{array}{l}\text { H ighestnew course qualification } \\
\text { level }\end{array}$} & \multicolumn{4}{|c|}{ \% allskills for Life leamers } \\
\hline & $\begin{array}{l}\text { W ave } 1 \\
\text { courses }\end{array}$ & $\begin{array}{l}\text { Y ear2 new } \\
\text { courses }\end{array}$ & $\begin{array}{c}\text { Y ear3 new } \\
\text { courses }\end{array}$ & $\begin{array}{c}\mathrm{N} \text { ew courses, } \\
\mathrm{Y} \text { ears } 2 \text { and } / \text { or } \\
3\end{array}$ \\
\hline low level/levelunknow n & 16 & 9 & 9 & 10 \\
\hline Entry level1 & 10 & 1 & 1 & 1 \\
\hline Entry level2 & 6 & 1 & 2 & 3 \\
\hline Entry level3 & 4 & 1 & 1 & 1 \\
\hline level1 & 21 & 13 & 8 & 15 \\
\hline level2 & 31 & 12 & 9 & 18 \\
\hline level3 & 6 & 9 & 7 & 13 \\
\hline level4 & 2 & 1 & 3 & 3 \\
\hline no details given & 4 & 52 & 60 & 36 \\
\hline total & 100 & 100 & 100 & 100 \\
\hline n w eighted & 644 & 644 & 644 & 644 \\
\hline
\end{tabular}

B ase: allSkills for Life leamers 
So far, this chapter has concentrated on participation in education and training. W e have not exam ined whether Skills for Life leamers w ere building up their skills. m oving to higher levels of com petence and know ledge. This is exam ined in this section, through exam ination of progression to higher-level courses. First the incidence of progression is exam ined (Section 4.4 .1 ) and then the types of courses to w hich Skills for Life leamers progressed (Section 4.42 ).

\subsubsection{Incidence of progression}

Progression, in term s of m oving to courses at a higher qualification level w as fairly com m on: 30 percent of Skills for Life leamers had done a new course by $Y$ ear 3 that w as at a higher level than any of those undertaken atW ave 1.

Progression $w$ as $m$ ost com $m$ on in the firstyear, $w$ ith 20 percentundertaking a new higher-level course by Y ear 2, whilst by Y ear 3, 15 per cent of form er Skills for Life leamers w ere doing a new course that year w hich w as at a higher level than any atW ave 1 (Table 4.6 ).

O ver these first tw o years progression tended to be in one step: $m$ oving to a new course (by Y ear 2) and progressing furtherw as rare. Few, six per cent, started a new course during $Y$ ear 3 that w as at a higher level than any new course undertaken during Y ear 2 and only one percent started a new course each year w hich w as at a higher level than any in the previous year.

Table 4 .6 Progression to higher-level courses, Y ears 2 to 3

\begin{tabular}{|l|c|c|c||c||}
\hline & \multicolumn{4}{|c||}{$\div$ Ski7ls for Life leamers } \\
\hline & Y ear2 v W 1 & Y ear3 v Y ear2 & Y ear3 v W 1 & $\begin{array}{c}\text { Y ear2 and/or } \\
\text { Y ear3 v W 1 }\end{array}$ \\
\hline no course (s) & 53 & 77 & 60 & 36 \\
\hline did low er levelcourse & 11 & 8 & 10 & 13 \\
\hline did sam e levelcourse & 9 & 7 & 9 & 13 \\
\hline did higher-levelcourse & 20 & 6 & 15 & 30 \\
\hline levelof course(s) unknown & 8 & 2 & 6 & 9 \\
\hline total & 100 & 100 & 100 & 100 \\
\hline n w eighted & 644 & 644 & 644 & 644 \\
\hline
\end{tabular}

The table com pares the highest course level betw een the years indicated. Thus if a person takes a higher-level course during $Y$ ear 2 than they did atW ave 1, butno course during $Y$ ear 3 , they w ill be recorded as follow s: in colum n 'Y ear $2 \mathrm{v} \mathrm{W} \mathrm{1'} \mathrm{-} \mathrm{did} \mathrm{higher-level} \mathrm{course;} \mathrm{in} \mathrm{colum} \mathrm{ns} \mathrm{'Y} \mathrm{ear} 3 \mathrm{v}$ Y ear 2' and 'Y ear $3 \mathrm{v}$ W 1' - no course; and colum n 'Y ear2 and/orY ear3 v W 1' - did higher-levelcourse.

Base: allskills for Life leamers

M ost progression w as to Level2 courses ${ }^{4}$ or higher (Table 4.7). O ver the two years since $W$ ave 1 :

24 per cent of Skills for Life leamers had started a higher-level course (com pared $w$ ith their highest levelY ear 1 course) at Level 2 or higher:

0 nine percentatLevel 2 and

\footnotetext{
${ }^{4}$ Figures relate to the highest level course to w hich a leamer had progressed atY ear 2 or $\mathrm{Y}$ ear 3 and to any leaming at that level. They do not indicate w hether leamers w ere undertaking leaming to reach a fullLevel2 (the equivalentof $5 \mathrm{~A}$ *-C grades atG CSE).
} 
o 15 percentatLevel3 orhigher.

a further six percenthad progressed to a Levell course.

Table 4 .7 Progression: highest course level, Y ears 1 to 3

\begin{tabular}{|c|c|c|c|c|}
\hline & \multicolumn{4}{|c|}{$\%$ Skills for Life leamers } \\
\hline & $\begin{array}{l}\text { Y ear } 2 \mathrm{~V} \\
\mathrm{~W} 1\end{array}$ & $\begin{array}{l}\text { Y ear 3 V } \\
\text { Y ear2 }\end{array}$ & $\begin{array}{l}\text { Y ear } 3 \mathrm{~V} \\
\mathrm{~W} 1^{\mathrm{a}}\end{array}$ & $\begin{array}{c}\text { Y ears } 2 \text { or } 3 \\
\text { vW } 1\end{array}$ \\
\hline $\begin{array}{l}\text { doing a higher-level course, } \\
\text { Levelof highest course }\end{array}$ & 20 & 6 & 15 & 30 \\
\hline Entry Level & 1 & 0 & 1 & 1 \\
\hline Level1 & 5 & 1 & 2 & 6 \\
\hline Level2 & 6 & 1 & 4 & 9 \\
\hline Level3 orhigher & 9 & 5 & 8 & 15 \\
\hline notdoing a new higher-levelcourse & 79 & 93 & 85 & 70 \\
\hline Total & 100 & 100 & 100 & 100 \\
\hline n w eighted & 644 & 644 & 644 & 644 \\
\hline
\end{tabular}

a inchudes those who did a higher-level course at $\mathrm{Y}$ ear 3 com pared $\mathrm{w}$ ith $\mathrm{Y}$ ear 2 (ie. those in the previous colum $\mathrm{n}$ ).

Base:allskills for Life leamers

M ore Skitls for Life leamers progressed in Y ear 2 than in Y ear 3 (20 percent com pared $\mathrm{w}$ ith 15 per cent). How ever, the decline in progression at $\mathrm{Y}$ ear $3 \mathrm{w}$ as confined to Level 2 courses and low er; the percentage progressing to Level $3 \mathrm{w}$ as $m$ aintained in $Y$ ear 3 (eight per cent progressed to Level 3 at $Y$ ear 3, com pared $w$ ith nine per cent at $Y$ ear 2). This pattem is likely to reflect, in part, a delay in progression until longer $W$ ave 1 courses ( $w$ hich extended into $Y$ ear 2 ) w ere com pleted and, in part, people progressing at $Y$ ear 2 and then to Level 3 at $Y$ ear $3 . N$ early all of the six percent who m ade progress each year (starting a higher-level course after one year and a still higher-level course after tw o) started a Level 3 course or higher in Y ear 3 (five percent of all Skiths for Life leamers).

Focussing on those progressing to Level2 and higher (Table 4 .8):

those w hose highest Y ear 1 course w as at Level 1 w ere m ost likely to progress (41 percentover the tw o subsequentyears);

o not surprisingly, this group were most likely to progress to Level 2 (27 per cent com pared w ith 14 per cent to higher levels);

0 progression $w$ as $m$ uch $m$ ore com $m$ on in $Y$ ear 2 than $Y$ ear 3 ( 30 percentand 14 percent respectively);

nearly one quarter (23 per cent) of those w hose highest $Y$ ear 1 course w as atLevel 2 progressed to Level 3 orhigher over the tw 0 subsequent years, $w$ ith the sam e percentage (15 percent) progressing in each year; (these figures inchude seven per cent took atLevel3 or higher course in both $Y$ ears 2 and 3 );

thinty-one per cent of those whose highest $Y$ ear 1 course w as at an Entry Levelprogressed: 
0 the largest percentage progressed to Level 1 (12 per cent); this $w$ as concentrated in $Y$ ear 1 ;

o eight per cent each progressed to Level 2 and to higher-level courses (16 percent in total);

o Level 2 and higher progression w as sim ilar in Y ear 2 and $Y$ ear 3 ;

o three percentprogressed $w$ ithin the Entry Levels.

15 per cent whose highest level course was at Level 3 or higher, progressed yethigher.

Table 4 .8 Progression, Y ears 2 to 3, by W ave 1 course level

\begin{tabular}{|c|c|c|c|c|c|c|c|c|c|c|}
\hline \multirow[b]{2}{*}{$\begin{array}{l}\text { highest } \\
\text { qualification } \\
\text { studying, w ave } 1\end{array}$} & \multicolumn{3}{|c|}{ Y ear $2 \mathrm{vW} 1$} & \multicolumn{3}{|c|}{ Y ear $3 \mathrm{v}$ W 1} & \multicolumn{3}{|c|}{ Totaly ears 2 or $3 \mathrm{~V} \mathrm{~W} 1^{\mathrm{a}}$} & \multirow[b]{2}{*}{$\mathrm{n}$} \\
\hline & $\begin{array}{c}\text { Level } \\
1\end{array}$ & $\begin{array}{c}\text { Level } \\
2\end{array}$ & $\begin{array}{c}\text { Level } \\
3 \text { or } \\
\text { higher }\end{array}$ & $\begin{array}{c}\text { Level } \\
1\end{array}$ & $\begin{array}{c}\text { Level } \\
2 \\
\end{array}$ & $\begin{array}{c}\text { Level } \\
3 \text { or } \\
\text { higher }\end{array}$ & $\begin{array}{c}\text { Level } \\
1\end{array}$ & $\begin{array}{c}\text { Level } \\
2\end{array}$ & $\begin{array}{c}\text { Level } \\
3 \text { or } \\
\text { higher }\end{array}$ & \\
\hline Entry levels & $10^{\mathrm{b}}$ & 5 & 5 & $5^{\mathrm{C}}$ & 6 & 5 & $12^{\mathrm{d}}$ & 8 & 8 & 266 \\
\hline level1 & & 19 & 11 & & 9 & 5 & & 27 & 14 & 127 \\
\hline level2 & & & 15 & & & 15 & & & 23 & 199 \\
\hline level3 orhigher & & & 8 & & & 11 & & & 15 & 52 \\
\hline Total & & 6 & 9 & & 4 & 8 & & 9 & 14 & 644 \\
\hline
\end{tabular}

Row percentages: percent of those $w$ ith a given highest levelW ave 1 course progressing to each level

a Those w ho took a higher-level course during either $Y$ ear 2 or $Y$ ear 3 . Som e took a higher-levelcourse than at W 1 during both $Y$ ear 2 and $Y$ ear 3 and at the sam e higher level. Therefore data does not sum across row s to the 'Total Y ears 2 or $3 \mathrm{v} \mathrm{W} \mathrm{1'.} \mathrm{(E} \mathrm{g.} 15$ per cent of Skills for Life leamers took a W 1 Level 2 course and a Level 3 (or higher) course during Y ear 2, also 15 per cent took a W 1 Level 2 course and a Level 3 (or higher) course during Y ear 3 . In total 23 per cent took a W 1 Level 2 and a higher-level course during Y ear 2 and/or Y ear 3, inchuding seven per cent who took at Level 3 (or higher) course during both $Y$ ears 2 and 3 ).

$b, c$ in addition, tw o per centprogressed to a higher Entry Level

d in addition, three per centprogressed to a higher Entry Level

\subsection{Progression: types of courses of those progressing}

The follow ing describes the types of new courses pursued by those who progressed to a higher-level course. It covers all new courses this group undertook, not just those at the higher level.

A s w ith new course starts (Section 4.3.1), the new courses started by those progressing to higher-level courses show ed a shift to vocational courses and aw ay from basic skills courses (Table 4.9). H ow ever, unlike allnew course starts, there w as also a shift tow ards academ ic courses.

of those progressing to a higher level course, 68 per cent ( $Y$ ear 2 ) and 73 per cent ( $Y$ ear 3 ) started new vocational courses, com pared w ith 41 percentdoing a vocational course at Y ear 1 ;

of those progressing to a higher level course, 33 per cent (Y ear 2) and 44 per cent ( $Y$ ear 3 ) started new academ ic courses, com pared w ith 27 percentdoing an academ ic course at Y ear 1 ; 
of those progressing to a higher level course, 71 per cent ( $Y$ ear 2 ) and 52 percent ( $Y$ ear 3) started new basic skills courses, com pared $w$ ith 83 percentdoing a basic skills course at Y ear 1 .

Table 4 . 9 Progression: courses of those progressing to higher-levelcourses, Y ears 2 and 3

\begin{tabular}{|c|c|c|c|c|}
\hline & \multirow{2}{*}{$\begin{array}{l}\text { \% Ski7ls for } \\
\text { Life leamers } \\
\text { courses W } 1\end{array}$} & \multicolumn{3}{|c|}{ \% Skills for Life leamers on a higher-levelcourse } \\
\hline & & Y ear $2 \mathrm{v} \mathrm{W} 1$ & Y ear3 vW 1 & $\begin{array}{c}\text { Y ears } 2 \text { or } 3 \mathrm{~V} \\
\mathrm{~W} 1\end{array}$ \\
\hline Basic skills & 83 & 71 & 52 & 71 \\
\hline literacy & 65 & 43 & 29 & 44 \\
\hline num eracy & 47 & 38 & 28 & 40 \\
\hline com bined literacy and num eracy & 4 & & & \\
\hline Key Skills & 16 & 22 & 20 & 29 \\
\hline ESO L & 1 & 6 & 1 & 4 \\
\hline A cadem ic qualifications & 27 & 33 & 44 & 38 \\
\hline GCSE & 26 & 19 & 16 & 21 \\
\hline A orA S Levels, A ccess course & 2 & 11 & 15 & 15 \\
\hline degree, H N D ,H N C , nursing, teaching & 2 & 6 & 15 & 9 \\
\hline V ocationalqualifications & 41 & 68 & 73 & 81 \\
\hline NVQ & 4 & 16 & 29 & 24 \\
\hline GNVQ & 0 & 5 & 4 & 5 \\
\hline C ity and G uilds & 16 & 28 & 10 & 25 \\
\hline RSA & 2 & 1 & 1 & 1 \\
\hline BTEC & 1 & 5 & 12 & 8 \\
\hline $\mathrm{ONC}$ & 1 & 2 & 4 & 3 \\
\hline CLA IT/other IT & 10 & 13 & 9 & 18 \\
\hline other & 14 & 18 & 20 & 29 \\
\hline did notknow on a course & 7 & & & \\
\hline Totaldoing a higher-level course & 100 & 100 & 100 & 100 \\
\hline n unweighted & 644 & 131 & 98 & 191 \\
\hline n w eighted & 646 & 108 & 91 & 168 \\
\hline
\end{tabular}

Bases are: all Skills for Life leamers colum n 2; Skills for Life leamers who w ere on a higher-level course, colum ns 3 to 5 .

The table show s all courses for Y ear 1 (colum n 2) and the new courses pursued by those who had progressed to a course at a higher level than the highest level course done atW ave 1 (colum ns 3 to 5). Respondents $m$ ay be doing $m$ ore than one course, not all of w hich $m$ ay be higher than the highest level W ave 1 course.

Exam ining these new courses in detail:

forvocational courses:

0 grow th w as particularly $\mathrm{m}$ arked for $\mathrm{NV} \mathrm{s}$, grow ing from four per cent in $Y$ ear 1 , to 16 per cent in $Y$ ear 2 to 29 per cent in Y ear 3;

0 grow th $w$ as strong for $C$ ity and $G$ uilds in $Y$ ear2 (28 percentof new course starts com pared $w$ ith 16 per cent of $Y$ ear 1 courses) but tailed off in $Y$ ear 3 (ten per cent); 
0 grow th $w$ as strong for B TEC S in Y ear 3 (12 per cent, com pared $\mathrm{W}$ ith one percent in $\mathrm{Y}$ ear 1 and five percent in $\mathrm{Y}$ ear 2$)$;

for academ ic courses, new starts shifted to higher-level courses:

o new starts in GCSEs declined over Y ears 2 and 3 com pared $\mathrm{w}$ ith participation at $Y$ ear 1 (26 per cent in $Y$ ear 1,19 per cent in $Y$ ear 2 and 16 percent in $Y$ ear 3$)$;

o grow th w as strong for A Levels, A S Levels and A ccess courses (tw 0 per cent in $Y$ ear 1, eleven per cent in $Y$ ear 2 and 15 per cent in $Y$ ear 3);

o grow th w as also strong for degrees, H N Cs, teaching and sim ilar courses in $Y$ ear 3 (tw o percent in $Y$ ear 1 , six percent in $Y$ ear 2 and 15 percent in $Y$ ear 3 );

decline occurred in all types of basic skills courses $w$ ith the exception of Key Skills courses:

0 decline w as greatest for literacy courses (65 per cent in $Y$ ear 1 , 43 percent in $Y$ ear 2 and 29 percent in $Y$ ear 3 ).

These pattems strongly suggest that, for those w ho progressed, Skills for Life courses acted as a springboard to vocational and academ ic qualifications.

\subsubsection{Progression : participation in higher levelnew courses}

This section describes how the pattems discussed in the previous section translate into the percentage of Skills for Life leamers pursuing different types of new courses w hilsthaving progressed ${ }^{5}$.

In Y ear 2, sim ilar percentages of Skills for Life leamers had progressed to a higher-level course and had started a new basic skills course or a new vocational course (Table 4.10$)$ :

16 per cent of all Skills for Life leamers had progressed to a higherlevel course and had started a new basic skills course

15 per cent of all Skills for Life leamers had progressed to a higherlevel course and had started a new vocational course

From Y ear 2 to Y ear 3, there was little decline in the percentage starting vocational courses and by Y ear 3 new vocational courses had overtaken new basic skills courses:

12 per cent of all Skills for Life leamers had progressed to a higherlevel course and had started a new vocational course ( $Y$ ear 3)

eight per cent of all Skills for Life leamers had progressed to a higherlevelcourse and had started a new basic skitls course (Y ear 3)

${ }^{5}$ The difference in percentages betw een this and the previous section is because this section refers to the percentage of all Skills for Life leamers. The previous section (4.42) exam ined the percentage of new course starts for those w ho progressed. 
Table 4.10 Progression: incidence of new course types and progression to higher-level courses, $Y$ ears 2 and 3

\begin{tabular}{|c|c|c|c|c|}
\hline & \multicolumn{4}{|c|}{ \% Skills for Life leamers } \\
\hline & courses W 1 & $\begin{array}{l}\text { higher level } \\
\text { Y ear } 2 \text { v W } 1\end{array}$ & $\begin{array}{c}\text { higher level } \\
\text { course Y ear } 3 \\
\text { v W } 1\end{array}$ & $\begin{array}{l}\text { higher level } \\
\text { course Y ears } \\
2 \text { or } 3 \text { V W } 1\end{array}$ \\
\hline Basic skills & 83 & 16 & 8 & 21 \\
\hline literacy & 65 & 10 & 5 & 13 \\
\hline num eracy & 47 & 8 & 5 & 12 \\
\hline com bined literacy and num eracy & 4 & 0 & 0 & 0 \\
\hline Key Skills & 16 & 5 & 3 & 9 \\
\hline ESOL L & 1 & 1 & 0 & 1 \\
\hline A cadem ic qualifications & 27 & 7 & 7 & 11 \\
\hline GCSE & 26 & 4 & 3 & 6 \\
\hline A orA S Levels, A ccess course & 2 & 2 & 2 & 5 \\
\hline degree, H N D , H N C , nursing, teaching & 2 & 1 & 2 & 3 \\
\hline Vocationalqualifications & 41 & 15 & 12 & 24 \\
\hline $\mathrm{NVQ}$ & 4 & 3 & 5 & 7 \\
\hline GNVQ & 0 & 1 & 1 & 2 \\
\hline C ity and G uilds & 16 & 6 & 2 & 7 \\
\hline RSA & 2 & 0 & 0 & 0 \\
\hline BTEC & 1 & 1 & 2 & 2 \\
\hline $\mathrm{ONC}$ & 1 & 0 & 1 & 1 \\
\hline CLA IT/other IT & 10 & 3 & 2 & 5 \\
\hline other & 14 & 4 & 3 & 8 \\
\hline did notknow on a course & 7 & & & \\
\hline Totaldoing a higher-levelcourse & $100^{a}$ & 22 & 16 & 30 \\
\hline no know n higher-levelcourse & na & 78 & 84 & 70 \\
\hline Total & 100 & 100 & 100 & 100 \\
\hline n unw eighted & 644 & 596 & 608 & 644 \\
\hline n w eighted & 646 & 589 & 612 & 646 \\
\hline
\end{tabular}

B ase is allskills for Life leamers

${ }^{\mathrm{a}}$ A ll courses atW ave 1

The table show s all courses at $W$ ave 1 (colum $n$ 2) and the new courses pursued by those who had progressed to a course at a higher level than the highest level course done atW ave 1 (colum ns 3 to 5). Respondents $m$ ay be doing $m$ ore than one course, notall of w hich $m$ ay be higher than the highest level W ave 1 course.

For academ ic courses, in each of $Y$ ear 2 and Y ear 3, seven per cent of all Skitls for Life leamers had progressed to a higher-level course and had started a new academ ic course.

A cross the tw o years, this totalled:

24 per cent of all Skills for Life leamers who had progressed to a higher-level course and had started a new vocationalcourse

21 per cent of all Skitls for Life leamers who had progressed to a higher-level course and had started a new basic skills course 
eleven per cent of all Skills for Life leamers who had progressed to a higher-level course and had started a new academ ic course.

These percentages suggest that Skiths for Life courses result in progression for a substantial percentage of participants.

\section{Factors affecting continuation and progression}

\subsubsection{Introduction}

The factors associated $w$ ith starting new courses and progressing to a higherlevel course w ere exam ined using logistic regression, so that the com bined effect of different factors could be assessed.

The factors exam ined w ere:

the influence ofW ave 1 courses and the outcom es from these courses; previous education, skills and qualifications;

personal characteristics;

econom ic characteristics and

continuation of a W ave 1 course

Full results are given in A ppendix 3 .H ere, the m ain findings are discussed.

The m odels w ere better at explaining progression (i.e. starting a higher-level course than the highest level undertaken at $W$ ave 1 ) and less good at explaining starting new courses generally (w hether at a higher level or not). They were particularly poor at explaining w ho started a new course during $Y$ ear 2 . This suggests either that the factors influencing starting a new course were not am ong those collected by our study or thatw hether a leamer started a new course one year on from their basic skills course could not be explained system atically, and w as in fact fairly random. In our discussion below, we therefore concentrate on the findings for progression.

W e focus on factors either which w ere significant in a num ber of m odels or which were both significant and have a strong, underlying theoretical basis for influencing take up or progression. This is to avoid draw ing conchusions based on spurious correlations? .

\section{Factors affecting progression: $W$ ave 1 courses}

A num ber of $W$ ave 1 course characteristics and course-related factors w ere associated with progression. The follow ing course characteristics appeared to influence progression:.

6 The models were run both $\mathrm{w}$ ith continuation of a $\mathrm{W}$ ave 1 course as an interaction term (during Y ear 2 for $W$ ave 2 outcom es and during Y ear 3 for $W$ ave 3 outcom es) and w ithout this interaction term. The models $\mathrm{w}$ ith the interaction term perform ed slightly better and so are the ones presented here.

${ }^{7} \mathrm{~W}$ ith a larger sam ple size, w e could have used a higher confidence level (than five per cent) instead. It is worth rem em bering that $w$ ith a five per cent confidence level, for every tw enty explanatory factors inchuded in a regression, one w ill probably be statistically significant for purely random reasons. 
C ourse level: those w ho w ere on low er level courses at $\mathrm{W}$ ave $1 \mathrm{w}$ ere m ore likely to progress.

0 progression by $\mathrm{Y}$ ear $2 \mathrm{w}$ as m ore com $\mathrm{m}$ on for those whose highest level course atW ave $1 \mathrm{w}$ as below Level 3

o progression during Y ear 3 steadily rose as highest level of course at $W$ ave 1 declined, being greatest for those whose highestW ave 1 course w as atan entry level courses

Vocational courses: those who had been on vocational courses at W ave 1 w ere m ore likely to have progressed to a higher-level course during $Y$ ear 3 , although this effect $w$ as not apparent during $Y$ ear 2 .

This $m$ ay have been because those taking a vocational course at $W$ ave $1 \mathrm{w}$ ere likely to be still be doing a vocational course at the sam e level during $Y$ ear 2, but had com pleted that level and m oved onto a new levelby $Y$ ear 3 .

N ot surprisingly, outcom es of $W$ ave 1 courses appeared to influence whether leamers started a new course and progressed to a higher-level course.

D ropout of W ave 1 courses appeared to affect progression:

0 those who dropped out of a W ave 1 course w ere less likely to start a new course during either $Y$ ear 2 or $Y$ ear 3 , but

0 those who dropped out of their original W ave 1 Skills for Life course, but continued another $\mathrm{W}$ ave 1 course during $\mathrm{Y}$ ear 2 w ere $m$ ore likely to start a new, higher-levelcourse during $Y$ ear 2 .

This pattem $m$ ay be because som e dropoutw illbe due to sw itching to a m ore appropriate course. Thus, although drop-outm ay reflect loss of m otivation, it $m$ ay also reflect strong m otivation to leam and $m$ ake progress.

0 those who dropped out of a course during Y ear 2 w ere less likely to progress during $Y$ ear 3 .

Com pletion of $\mathrm{W}$ ave 1 courses tended to increase the likelihood of progression. Those who had both com pleted their original $W$ ave 1 Skills for Life course and had been doing another course at W ave 1 which continued into Y ear 2, were also m ore likely to take up new courses.

Q ualification gain

o qualifications gained during Y ear 2 did not seem to influence either the take-up of new courses orprogression.

\subsubsection{F actors affecting progression: E ducation, skills and qualifications}

Previous education, skiths and qualifications appeared to influence the likelihood both of continuation of leaming and of progression to higher-level courses. Tw 0 factors stand out strongly:

those w ho had left continuous full-tim e education at a later age (19 and over) were 
0 m ore likely to continue onto a new course in Y ear2 or 3

0 m ore likely to progress to a higher-level course in Y ear 2 ;

those w ho w ere better qualified w ere

o m ore likely to startnew courses

o m ore likely to progress

o those $w$ ith Level 3 qualifications (at W ave 1), in particular, were $m$ ore likely to start new courses in Y ears 2 and 3 and to progress in $Y$ ear 2 .

This suggests that Skills for Life courses were providing rem edial literacy or num eracy training for those otherw ise well-qualified or enabling this group to fill a gap in their set of qualifications (e.g.G CSE English orM aths) to enable them to progress further.

Those who said that they had had a positive experience of school w ere less likely to have progressed onto a higher-level course in Y ear 2 and less likely to have started a new course in $Y$ ear 3 .

A lthough there w ere som e associations betw een different levels of literacy and num eracy com petence at $W$ ave 1 and subsequent leaming and progression, these did not show an entirely consistentpattem. H ow ever:

those $\mathrm{w}$ ith entry level 2 or 3 literacy com petence at $\mathrm{W}$ ave $1 \mathrm{w}$ ere $\mathrm{m}$ ore likely than those in other categories to have progressed to a higherlevelcourse in both $Y$ ears 2 and 3 ;

those $w$ ith entry level 2 or 3 num eracy com petence at $W$ ave $1 \mathrm{w}$ ere m ore likely to have progressed to a higher-level course in either $Y$ ear 2 orY ear 3 .

On the other hand, those who had self-perceived literacy and num eracy problem s at $W$ ave 1 , or w hose first language was not English, and w ere continuing their $\mathrm{W}$ ave 1 course in Y ear 3, w ere less likely than those who had not reported literacy or num eracy problem s atW ave 1 to have progressed to a higher-level course. It is possible that those $w$ ith self-perceived literacy and num eracy difficulties had problem s w hich w ere qualitatively different from those of people w ho w ere tested as being at the sam e level but did not perceive they had problem s. It is also possible that they have less confidence, and are therefore m ore reluctant to enrol for higher-level courses.

\section{5.4 F actors affecting continuation and progression: Personalcharacteristics and econom ic activity}

Few personal characteristics in the model seem ed to be associated $\mathrm{w}$ ith whether Skills for Life leamers started a new course or progressed. Those that w ere, w ere related to health, ethnicity, children, age and gender:

there appeared to be some decline in new course start-up and progression $w$ ith age, but the effect $w$ as $s m$ all and confined to new course start-up in $Y$ ear 2 and progression in $Y$ ear 3 ; 
those $\mathrm{w}$ ith better health were m ore likely to take up a new course in both $Y$ ear 2 and Y ear 3. H ow ever, atboth w aves they w ere less likely to have progressed to a course at a higher level.

The effects of gender, ethnicity, having children and econom ic activity and related factors w ere inconsistent across years and betw een start-up and progression and so did not appear to provide a reliable indication of their influence.

\subsection{Sum m ary}

\subsubsection{Sum m ary: continued participation in education and training}

Skitls for Life courses appear to encourage continued participation in education and training:

72 per cent of Skills for Life leamers were still in education and training in $Y$ ear 2 ;

57 per cent of Skills for Life leamers were still in education and training in $Y$ ear 3 ;

64 per cent had started new courses $\mathrm{w}$ ithin tw o years (47 per cent in $Y$ ear 2 and 40 percent in $Y$ ear 3 ).

The pattem of further study was com plex, w ith m any starting new courses whilstcontinuing existing courses:

50 percentcontinued in education and training over the tw o years;

22 percentcontinued into a second year, butnota third;

a sm all percentage m oved out of education and training in $Y$ ear 2 , but started a course in $Y$ ear 3 .

\subsection{Sum m ary: new courses and progression}

Skitls for Life provided a spring board for developm ent tow ards higher-level courses and tow ards m ore job-oriented training:

34 percent of Skills for Life leamers had started a new course atLevel 2 or above in eitherY ear 2 or $Y$ ear 3 ;

30 per cent of Skills for Life leamers had started a new, higher-level course in either $Y$ ear 2 or 3 ; progression $w$ as $m$ ore com $m$ on in $Y$ ear 2 than $Y$ ear 3 ;

by Y ear 3, 24 percent of Skills for Life leamers had m oved to a higherlevel course at Level 2 or higher (inchuding 15 per cent to Level 3 or higher) ;

alm ost half (48 per cent) of Skills for Life leamers had started a new vocational course in eitherY ear 2 or 3 ;

43 percenthad started a new basic skills course, $w$ ith the percentage of new basic skiths course starts declining across the years;

17 per cent of Skills for Life leamers had started a new academ ic course; academ ic new starts were $m$ ore com $m$ on for those who had 
started higher-level courses and m any of these were progressing to Level 3 and higher;

$\mathrm{NV} Q$, C ity and G uilds and IT qualifications w ere $\mathrm{m}$ ost com $\mathrm{m}$ on.

Progression $w$ as $m$ ost com $m$ on for those whose highest level of study in $Y$ ear $1 \mathrm{w}$ as Level1, butprogression w as high from all levels:

41 per cent progressed to Level 2 courses or higher (14 per cent of these progressed to Level3 orhigher) from Levell courses;

16 per cent progressed to Level 2 or higher from Entry Level 1 courses;

23 percentprogressed to Level3 orhigher from Level2 courses;

15 percentprogressed to Level4 orhigher from Level3 courses.

\subsubsection{Sum m ary: factors affecting progression}

There are relatively few personal and educational characteristics which are associated $w$ ith new course participation and progression. This suggests that Skiths for Life courses can act as a route to leaming for a w ide range of people, and there appear to be few factors, apart from health, which act as a bamier to future leaming.

The findings identify the im portance of progression, rather than of doing new courses, and particularly thatprogression atone stage leads to furtherprogression.

Participation in Skills for Life seem ed to provide an effective stepping stone to progression.

The findings are very positive in relation to im provem ents am ongst the least skilled, as progression increased as course level decreased. At the sam e tim e, those w ho w ere m ost likely to progress w ere notnecessarily the least qualified, as those $\mathrm{w}$ ith level 3 qualifications (at W ave 1) w ere also more likely to progress. Sim ilarly, those who had stayed in full-tim e education beyond the age of $18 \mathrm{w}$ ere also $\mathrm{m}$ ore likely to progress.

The findings em phasise the im portance of positive outcom es from courses in increasing participation in new courses and progression:

com pletion is particularly im portant in this respect

qualification gain is less im portant. 
The study w as established to assess the im pact of participation in Skitls for Life courses on econom ic outcom es, both for the individual and the econom $y$. The previous report found that, after one year, there w as no im pact on em ploym ent and eamings, but that, in term s of employability indicators, sm all, but significant, im provem ents were identified in term s of self-esteem, health and em ploym ent com $m$ itm ent ( $M$ eadow s and $M$ etcalf, 2005). W e conchided that, for people w ith low basic skills, the path to im proved em ploym ent would tend to be from basic skiths courses, via vocational and academ ic courses and that this path could be relatively long. The current findings strongly support this hypothesis. M oreover, they indicate that Skills for Life courses are an effective springboard onto this path, increasing participation in education and training and leading to the build up of em ploym entrelated qualifications and skills.

\subsubsection{Im pacton LabourM arketo utcom es}

In term s of em ploym ent, sm all but significant effects of Skills for Life courses on eamings and on em ploym ent have started to be identified. Skills for Life courses continue to have an im pact on em ployability, through im proved self-esteem, greater participation in education and training and im proved health. There are indications that som e of these outcom es (em ploym ent in particular) are likely to im prove in the future.

The m ost im portant im pact relates to greater participation in education and training. A dults $\mathrm{w}$ ith poor basic skills have often not had good experiences at school, and it is know $n$ that those $w$ ith poor school experiences are difficult to attract back into leaming as adults. Participation on Skills for Life courses has increased com m itm ent towards education and training and increased participation in new courses.

Indeed, this greater participation in education and training is liable to be depressing the em ploym ent im pact of Skills for Life courses at this stage. A though Skitls for Life leamers' em ploym ent rates have been higher (and the differences $\mathrm{w}$ ith the comparison group larger) at each successive wave of the study, greater participation in full-time education m eans that the impact is not statistically significant. It is, how ever, reasonable to expect that som e of those cumently taking education and training courses $w$ ill $\mathrm{m}$ ove into em ploym entover the next few years.

\subsection{Educationalparticipation and developm ent}

The impact evaluation showed that Skills for Life courses increased participation in education and training, $w$ ith Skills for Life leamers m ore likely to start new courses than non-Skills for Life leamers.

Further analysis of Skills for Life leamers' participation education and training show ed that the nature of these courses was very likely to im prove em ploym ent prospects. Education and training paths w ere often upw ards, to higher-level courses. Indeed, 30 per cent of Skills for Life leamers took a higher-level course in the subsequent tw o years. There w as also a shift aw ay from basic skills courses tow ards 
vocational courses, particularly, and, for those entering higher-level courses, tow ards academ ic courses.

Positive outcom es from first year courses were im portant indicators of participation in new courses and of progression. Key was course completion. $Q$ ualification gain w as of less im portance.

\section{Socialinchusion}

O bviously, im proving basic skills w illm ake a contribution to social inchusion, as will increased em ploym ent, education and training. How ever, Skills for Life appeared to be m aking an additional contribution, through achieving equal outcom es inespective of im portant personal characteristics. No differences were found in further participation and progression in education and training by gender, ethnicity or parenthood. Som e difference $w$ as found by age, albeitsm all, and by health .

M oreover, Skills for Life appeared to be addressing the needs of the least skilled as those on the low est level courses w ere the m ost likely to m ove on to a higher-level course. H ow ever, this bias tow ards the least skills w as not clear cut, as those $\mathrm{w}$ ith the highest qualifications (at the start of the study) and those who had initially left full-tim e education aged 19 and overw ere also m ore likely to progress. 


\section{A ppendix 1:W ave 3 Survey TechnicalR eport}

Prepared by: $\mathrm{N}$ ick Colem an and $\mathrm{H}$ annah Carpenter, BM RB SocialR esearch ${ }^{8}$

\section{A 1.1 Introduction}

This technical reportprovides details on the $\mathrm{W}$ ave 3 of the Leamers Panel survey, camied outby BM RB Social R esearch, in conjunction w ith the $N$ ational Institute of Econom ic and Social R esearch (N $\mathbb{E} S R$ ), on behalf of the D epartm ent for Education and Skills (D fES).

The survey as a w hole exam ines basic skills training in England, and w as designed to obtain interview s from both leamers and non-leamers. This report should be read in conjunction $\mathrm{w}$ ith the technical reports from $\mathrm{W}$ ave 1 and $\mathrm{W}$ ave 2 , w hich includes details on the design of the survey. These details are not repeated in this report.

The reportprovides details on:

\section{D esign}

Sam ple selection

Q uestionnaire

Fieldw olk procedures

Response rates

A nalysis

W eighting.

D esign

The study design is described in detail in the $\mathrm{W}$ ave 1 technical report. Itw as based on the need to com pare outcom es fora sam ple of people w ho, at the startof the study, received basic skills training (leamers) and those w ho did not (non-leamers or control sam ple). To m axim ise the effectiveness of the analysis, the leamers sam ple and control sam ple needed to be m atched closely, in term s of dem ographic features, as w ell as levels of literacy and num eracy.

The survey uses a longitudinaldesign in order to exam ine individuals' progress and outcom es overtim e. The W ave 3 survey involved re-contacting individuals w ho had been interview ed atW ave 1, and again atW ave 2, and canying out a third interview. W ave 3 fieldw ork took place one year afterW ave 2 , and tw 0

8 Part of BM RB Intemational Lim ited. BM RB N C /W /45102075. BM RB Intemational is ISO 9001 accredited, and is certified as working to the requirem ents of M RQSA/BS7911 m arket research quality standards 
years afterw ave 1. A fourth w ave of fieldw ork (in 2006) is also inchuded in the study.

Sam ple selection

A tW ave 2, interview s w ere conducted w ith 2,216 individuals: 1,094 leamers and 1,122 non-leamers (controlsurvey). A s partof the $W$ ave 2 interview, respondents w ere asked w hether they w ould be w illing to be re-contacted. A total of 2,033 respondents agreed to be re-contacted: 1,002 leamers and 1,031 non-leamers, 92 percentof $W$ ave 2 respondents in each case. These 2,033 individuals represented the sam ple for the $W$ ave 3 survey.

The sam ple w as split into three batches in order to ensure that respondents w ere interview ed as close as possible to one year after theirw ave 2 interview . The batches w ere as follow s:

\begin{tabular}{|l|c|c|}
\hline & Num berof cases & Fieldw olk dates \\
\hline Batch 1 & 536 & January-M arch \\
\hline Batch 2 & 719 & M arch-M ay \\
\hline Batch 3 & 777 & M ay-Jine \\
\hline
\end{tabular}

Q uestionnaire D evelopm ent

M ain Questionnaire

The questionnaire $w$ as designed by $N \mathbb{E} S R$, in consultation $w$ ith BM RB and $D$ fES. The average interview length w as $50 \mathrm{~m}$ inutes.

The agreed questionnaire w as program m ed foruse as a CA PI (Com puter A ssisted Personal Interview ing) questionnaire, using $Q$ uantum softw are. The program $m$ ing w as camied outatBM RB .

Literacy and $\mathrm{N}$ um eracy Tests

A s part of the interview, a literacy and num eracy testw as adm inistered. At $\mathrm{W}$ ave 1 ithad been agreed that the test should last $15 \mathrm{~m}$ inutes on average, and the sam e testw as used atW aves 2 and 3.

This W ave 1 testw as a shortened version of the literacy and num eracy test thathad been used on the SFL survey, produced by the Centre forD eveloping and Evaluating Lifelong Leaming (CD ELL) at the U niversity of N ottingham . CD ELL produced this shortened version of the SFL test.

F ieldw ork

A Il fieldw olk w as camied out face-to-face by The O perations Centre. BM RB and The $O$ perations $C$ entre are both a partof $K$ antar, the inform ation, insight and consultancy arm of W PP, The O perations Centre exists to provide all $\mathrm{K}$ antar's $\mathrm{U} \mathrm{K}$ com panies $w$ ith access to the bestoperations capabilities. 
Pilot

Itw as decided that it w ould notbe necessary to conduct a pilotatw ave 3 as the questionnaire $\mathrm{w}$ as very sim ilar to $\mathrm{W}$ ave 2 , and the contact procedure $\mathrm{w}$ as identical to $\mathrm{W}$ ave 2 .

\section{Advance letters}

Letters w ere sent to all respondents w ho w ere to be re-contacted for this survey. These letters inform ed respondents that they w ould be contacted, gave them som e background to the survey, and re-assured them aboutconfidentiality. Italso gave them BM RB 's contact details should they have any questions about the survey . The letter is show n below .

\section{Briefings}

A tW ave 2 , interview ers w ere briefed personally by the BM RB research team, but itw as considered unnecessary to re-brief interview ers again forW ave 3 (as there w ere very few differences betw een w aves). The sam e interview s w ho had w olked on W ave 2 of the survey w ere used to conduct interview s for W ave 3, and full w ritten instructions w ere provided to the interview ers. The instructions covered:

B ackground to the survey and objectives

O verall design

Content of interview er assignm ents

Contactprocedures

$\mathrm{W}$ ays of $\mathrm{m}$ axim ising response rates

$Q$ uestionnaire and test

A dm inistrative issues.

Incentives

A s this $w$ as the third tim e these respondents w ere contacted, it w as decided that incentives should be used atW ave 3. Incentives w ere notused atW aves 1 and 2 of this survey. The incentive w as a $£ 10 \mathrm{~W} \mathrm{H}$ Sm iths voucher. Interview ers gave one voucher to each respondentw ho they interview ed. The advance letter had already inform ed respondents exactly w hat the incentive w as.

$\mathrm{F}$ ieldw ork Tim ing

Fieldw ork took place betw een January and June 2005. The relatively long fieldw ork period w as determ ined by the need to stagger fieldw ork, so that respondents w ould be interview ed as close as possible to one year after theirw ave 2 interview . 
A dvance letter

Ref: $45102075 /$ seríl

Nam e

Address

January 2005

Dear

You very kindly heped us by taking part in an interview in yourhom e last year. This was aboutyourexperiences ofeducation and em pbym ent. The interview erw as from BM RB SocialR esearch, and the survey is on behalfof the Departm ent forEducation and Skills.

W hen you spoke to the interviewer bstyear, you said thatyou would be w illing to be contacted again. W e would very m uch like to speak to you again, to find outaboutyourexperiences in the hastyear. $W$ e are interested in speaking to a wide range ofpeople, so whateveryou have been doing in the lastyear, we would like to speak to you.

As a token of our appreciation we are offering a $£ 10 \mathrm{~W} \mathrm{H} \mathrm{Sm}$ iths voucher as a thank you to all those who take part in this im portant survey.

An interview er from The O perations Centre working on behalf of BM RB SocialR esearch w ill callatyour hom e. P lease note that the interviewerw in cany an identification card atall tm es. Everything thatyou say w illbe treated in the strictestconfidence by BM RB .

In the m eantm e, if you have any questions about the survey, please contactm e on 02084334408 .

Thank you very $m$ uch foryourhep in this im portantstudy.

Yours faithfulty

\section{Nid denam}

$\mathrm{N}$ ick Colem an

SeniorAssociate D irector

BM RB SocílR esearch 


\section{Contactprocedures}

A contact sheetw as issued for each respondent and interview ers w ere instructed only to interview the person nam ed on the contact sheet. Interview ers w ere required to $\mathrm{m}$ ake a $\mathrm{m}$ in'm um of five calls ateach address before retuming the contact sheetw ith a "no contact" outcom e.

A ll interview s w ere conducted in the respondent's hom e unless an altemative location w as requested by respondent (for exam ple the college w here they w ere studying at that tim e) .

M overs

W here the nam ed respondents had m oved from the listed address, interview ers attem pted to obtain an up-to-date address from the new occupant. W here no contact $\mathrm{w}$ ith the household w as possible, interview ers attem pted to contact neighbours, firstly in order to confirm whether the nam ed person w as still living there, and then if not, to try and obtain a new address.

W here a new address w as obtained, interview ers either visited the new address them selves (if itw as nearby) or retumed the contact sheet to the field office for reallocation to a different interview er.

Q uality ControlM easures

For all face-to-face surveys, the O perations Centre's standard quality control procedures exceed those stipulated by IQ CS (Interview erQ uality Controlschem e) and BS7911 (the B ritish Standard Specification forO rganisations conducting M arket Research) and are sum m arised as follow s:

Interview ers are accom panied by a Supervisor, for an aftemoon and/or evening, on at least three assignm ents a year.

Ten per centof respondents are re-contacted by phone or letteron all surveys.

$R$ esponse $R$ ates

Table A 1 . show s response rates for all respondents, splitby fieldw ork batch.

Table A 1. 1 Response rates for all respondents

\begin{tabular}{|l|c|c|c|c|c|c|c|c|}
\hline & \multicolumn{2}{|c|}{ Batch 1 } & \multicolumn{2}{|c|}{ Batch 2 } & \multicolumn{2}{c|}{ Batch 3 } & \multicolumn{3}{c|}{ Total } \\
\hline & No & $\%$ & No & $\%$ & No & $\%$ & No & $\%$ \\
\hline Totalsam ple & 536 & & 719 & & 777 & & 2032 & \\
\hline Interview S & 380 & 71 & 468 & 65 & 518 & 67 & 1366 & 67 \\
\hline M oved, not traced & 25 & 5 & 40 & 6 & 55 & 7 & 120 & 6 \\
\hline O pt-out & 17 & 3 & 13 & 2 & 8 & 1 & 38 & 2 \\
\hline Refusal & 31 & 6 & 58 & 8 & 54 & 7 & 143 & 7 \\
\hline No contact & 41 & 8 & 79 & 11 & 80 & 10 & 200 & 10 \\
\hline O ther & 42 & 8 & 61 & 8 & 62 & 8 & 165 & 8 \\
\hline
\end{tabular}


Table A 12 show s response rates for the leamer and controlsam ple separately (this distinction relates to their status atW ave 1 ). The response rates are very sim ilar for the tw o groups.

Table A 1.2 Response rates: leamers and controlsam ple

\begin{tabular}{|l|c|c|c|c|}
\hline & \multicolumn{2}{|c|}{ Leamers } & \multicolumn{2}{c|}{ Control } \\
\hline & No & $\%$ & No & $\%$ \\
\hline Totalsam ple & 1002 & & 1031 & \\
\hline Interview S & 682 & 68 & 674 & 65 \\
\hline
\end{tabular}

W hile it is notpossible to assess the im pact of the incentive, these response rates are higher than originally anticipated, and also higher than the response rates at W ave 2 (59\% am ongst leamers and 54\% for the control sam ple). This suggests that the incentive did help to boost response.

Analysis

Coding

O pen ended questions w ere coded by The O perations Centre's Coding departm ent. This com prised:

coding of industry and occupation for cument/previous w olk, using Standard IndustrialC lassification (SIC) and Standard O ccupational Classification (SO C 2000)

coding of responses to open ended questions, using code fram es designed by BM RB .

W eighting

W eights had been applied to the W ave 1 data, and these w eights w ere camied forw ard into the $W$ ave 3 data. A n additional w eightw as applied atW ave 3, to account fornon-response betw een $W$ aves 1 and 3. This w eightw as produced by com paring the profiles of the $W$ ave 1 and $W$ ave 3 interview ed sam ples on key characteristics. Specifically, this w eight reflected an adjustm ent for age, em ploym ent status and ethnicity ( $w$ ithin the controlsam ple) and age, gender, qualifications and first language ( $w$ ithin the leamers sam $p l e)$. Individual $w$ eights for leamers, reflecting non-response betw een $\mathrm{W}$ aves 1 and 3, w ere as follow s: 
Table A $1.3 \mathrm{~W}$ eights to adjust fornon-response betw een $\mathrm{W}$ aves 1 and 3 - Leamers group

\begin{tabular}{|c|c|c|c|c|}
\hline Age & G ender & Q ualifications & Language & W eight \\
\hline $16-18$ & M ale & Currently studying G C SE & English & 0.7251 \\
\hline $16-18$ & M ale & Cumently studying G C SE & N otEnglish & 0.7739 \\
\hline $16-18$ & M ale & N otstudying, have G CSE & English & 0.3609 \\
\hline $16-18$ & M ale & N otstudying, have G CSE & N otEnglish & 03818 \\
\hline $16-18$ & M ale & N otstudying, no G CSE & English & 1.1512 \\
\hline $16-18$ & $\mathrm{M}$ ale & N otstudying, no G CSE & N otEnglish & 0.5382 \\
\hline $16-18$ & M ale & Don'tknow & English & 1.3367 \\
\hline $16-18$ & M ale & Studying other & N otEnglish & 15377 \\
\hline $16-18$ & Fem ale & Cumently studying G C SE & English & 1.1357 \\
\hline $16-18$ & Fem ale & Cumently studying G C SE & N otEnglish & 0.4432 \\
\hline $16-18$ & Fem ale & N otstudying, have G CSE & English & 0.9384 \\
\hline $16-18$ & Fem ale & N otstudying, have G CSE & N otEnglish & 03166 \\
\hline $16-18$ & Fem ale & D on'tknow & English & 29396 \\
\hline $16-18$ & Fem ale & D on'tknow & N otEnglish & 0.7538 \\
\hline $16-18$ & Fem ale & Studying other & English & 42059 \\
\hline $19-24$ & M ale & Currently studying G C SE & English & 1.0289 \\
\hline $19-24$ & M ale & Currently studying G C SE & N otEnglish & 1.8995 \\
\hline $19-24$ & M ale & N otstudying, have G CSE & English & 0.8442 \\
\hline $19-24$ & M ale & N otstudying, no G CSE & English & 1.0764 \\
\hline $19-24$ & $\mathrm{M}$ ale & N otstudying, no G CSE & N otEnglish & 0.3166 \\
\hline $19-24$ & $\mathrm{M}$ ale & D on'tknow & English & 0.5540 \\
\hline $19-24$ & M ale & D on'tknow & N otEnglish & 12663 \\
\hline $19-24$ & $\mathrm{M}$ ale & Studying other & English & 1.0553 \\
\hline $19-24$ & Fem ale & Currently studying G CSE & English & 0.7914 \\
\hline $19-24$ & Fem ale & N otstudying, have G CSE & English & 0.7123 \\
\hline $19-24$ & Fem ale & N otstudying, no G CSE & English & 0.8231 \\
\hline $19-24$ & Fem ale & D on'tknow & English & 0.7387 \\
\hline $19-24$ & Fem ale & Studying other & English & 09497 \\
\hline $25+$ & M ale & Cumently studying G C SE & English & 0.8442 \\
\hline $25+$ & $\mathrm{M}$ ale & Currently studying G C SE & NotEnglish & 1.1080 \\
\hline $25+$ & M ale & N otstudying, no G CSE & English & 0.9158 \\
\hline $25+$ & $\mathrm{M}$ ale & N otstudying, no G CSE & NotEnglish & 1.4774 \\
\hline $25+$ & M ale & D on'tknow & English & 0.7387 \\
\hline $25+$ & $\mathrm{M}$ ale & Studying other & English & 0.8367 \\
\hline $25+$ & M ale & Studying other & N otEnglish & 12663 \\
\hline $25+$ & Fem ale & Cumently studying G C SE & English & 0.7387 \\
\hline $25+$ & Fem ale & Cumently studying G C SE & N otEnglish & 1.7412 \\
\hline $25+$ & Fem ale & N otstudying, have G CSE & English & 1.0553 \\
\hline $25+$ & Fem ale & N otstudying, have G CSE & N otEnglish & 12663 \\
\hline $25+$ & Fem ale & N otstudying, no G CSE & English & 0.9181 \\
\hline $25+$ & Fem ale & N otstudying, no G CSE & N otEnglish & 1.4246 \\
\hline $25+$ & Fem ale & D on'tknow & English & 0.8231 \\
\hline $25+$ & Fem ale & D on'tknow & N otEnglish & 1.4246 \\
\hline $25+$ & Fem ale & Studying other & English & 0.8058 \\
\hline $25+$ & Fem ale & Studying other & NotEnglish & 09497 \\
\hline
\end{tabular}

For the control sam ple, rim w eights w ere used for ethnicity and em ploym ent status, and a separate age w eightw as added. 
Table A 1. $4 \mathrm{R}$ im w eights to adjust fornon-response betw een $\mathrm{W}$ ave 1 and $\mathrm{W}$ ave 3 controlgroup

\begin{tabular}{|l|l|c|}
\hline Em ploym entstatus & E thnicity & W eight \\
\hline Em ployee & W hite B ritish & 0.8951 \\
\hline Em ployee & W hite Irish & 1.4640 \\
\hline Em ployee & W hite other & 3.0028 \\
\hline Em ployee & B lack C aribbean & 2.1552 \\
\hline Em ployee & A sian Indian & 1.8235 \\
\hline Em ployee & A sian Pakistani & 3.6852 \\
\hline Em ployee & Chinese & 1.3099 \\
\hline Em ployee & O ther & 3.7114 \\
\hline Em ployee & M ixed & 12803 \\
\hline Em ployee & Refused & 0.2620 \\
\hline Self-em ployed & W hite B ritish & 0.9276 \\
\hline Self-em ployed & W hite other & 3.1118 \\
\hline Unem ployed & W hite B ritish & 0.9147 \\
\hline Unem ployed & B lack C aribbean & 2.2024 \\
\hline Unem ployed & A sian Pakistani & 3.7660 \\
\hline Full-tim e education & W hite B ritish & 12751 \\
\hline Full-tim e education & M ixed & 1.8239 \\
\hline Part-tim e education & W hite B ritish & 2.2820 \\
\hline Full-tim e education w ith job & W hite B ritish & 0.3521 \\
\hline Full-tim e education w ith job & B lack Caribbean & 0.8477 \\
\hline On governm entschem e & W hite B ritish & 0.8693 \\
\hline Tem porarily sick ordisabled & W hite B ritish & 0.6709 \\
\hline Tem porarily sick ordisabled & B lack Caribbean & 1.6154 \\
\hline Perm anently sick ordisabled & W hite B ritish & 0.9009 \\
\hline Perm anently sick ordisabled & W hite Irish & 1.4734 \\
\hline Perm anently sick ordisabled & M ixed & 12885 \\
\hline Looking after fam ily orhom e & W hite B ritish & 3.0604 \\
\hline Looking after fam ily orhom e & W hite other & 2.1603 \\
\hline Looking after fam ily orhom e & A sian Indian & \\
\hline Looking after fam ily orhom e & M ixed & W hite B ritish \\
\hline Retired & A sian B angladeshi & \\
\hline O ther & & \\
\hline
\end{tabular}

Table A $1.5 \mathrm{~W}$ eights by age to adjust fornon-response betw een W ave 1 and W ave 3 controlgroup

\begin{tabular}{|l|l|}
\hline Age & W eight \\
\hline $16-24$ & 1.1063 \\
\hline $25-34$ & 1.1459 \\
\hline $35-44$ & 1.0461 \\
\hline $45-54$ & 0.8477 \\
\hline $55+$ & 0.6588 \\
\hline Refused & 0.8708 \\
\hline
\end{tabular}




\section{A ppendix 2: Logistic regression equation used for propensity score $m$ atching}

$\begin{array}{llll}\text { Table A 2 . } 1 \text { Logistic regression equation used forpropensity score m atching } \\ \text { Logistic regression } & \text { N um berofobs } & = & 3476 \\ & \text { LR chi2 (47) } & = & 1355.06 \\ & \text { Prob > chi2 } & = & 0.0000 \\ \text { Log likelihood }=-1724.63 & \text { Pseudo R } 2 & = & 02821\end{array}$

D ependentvariable: D oing a Skills for L ife course atW ave 1

\begin{tabular}{|c|c|c|c|c|c|c|c|}
\hline & O dds & Sig & Std Enr & $\mathrm{z}$ & $P>|z|$ & \multicolumn{2}{|c|}{ [Conf. Interval] } \\
\hline literacy test score entry level2 & 113678 & & 0.19042 & 0.77 & 0.444 & 0.81865 & 157855 \\
\hline literacy test score entry level3 & 0.58414 & $\star \star \star *$ & 0.10091 & -311 & 0.002 & 0.41636 & 0.81954 \\
\hline literacy test score level1 & 0.95446 & & 0.16261 & -027 & 0.784 & 0.68350 & 133285 \\
\hline literacy test score level2 & 0.02181 & $\star \star *$ & 0.02254 & -3.70 & 0.000 & 0.00288 & 016539 \\
\hline literacy test incom plete & 016850 & $\star \star \star$ & 0.06193 & -4.85 & 0.000 & 0.08199 & 0.34630 \\
\hline num eracy test score entry level2 & 0.73251 & $\star \star *$ & 0.07961 & -2.86 & 0.004 & 0.59198 & 090641 \\
\hline num eracy test score entry level 3 & 0.68973 & $\star \star$ & 0.11549 & -222 & 0.027 & 0.49676 & 095766 \\
\hline num eracy test score level 1 & 0.96295 & & 0.18305 & -020 & 0.843 & 0.66343 & 139770 \\
\hline num eracy test.score level2 & 1.42974 & & 0.31257 & 1.64 & 0.102 & 093147 & 219456 \\
\hline num eracy test incom plete & 2.78231 & $\star \star \star$ & 1.01698 & 2.80 & 0.005 & 135918 & 5.69553 \\
\hline qualifications below level1 & 153673 & $\star \star$ & 028057 & 2.35 & 0.019 & 1.07446 & 219789 \\
\hline qualifications level1 & 1.61368 & $\star \star \star$ & 0.18270 & 423 & 0.000 & 129254 & 2.01459 \\
\hline qualifications level2 & 1.76646 & $\star * *$ & 025989 & 3.87 & 0.000 & 132395 & 235687 \\
\hline qualifications level 3 & 136693 & & 025726 & 1.66 & 0.097 & 0.94525 & 197673 \\
\hline qualifications level4 & 1.00690 & & 020859 & 0.03 & 0.974 & 0.67088 & 1.51121 \\
\hline leftf-teducation age 16 or less & 1.05504 & & 0.17088 & 0.33 & 0.741 & 0.76807 & 1.44924 \\
\hline leftf-teducation age 17 & 1.44867 & $\star \star \star$ & 0.18445 & 2.91 & 0.004 & 1.12873 & 1.85929 \\
\hline did notgo to school & 3.44214 & & 2.48192 & 1.71 & 0.086 & 0.83768 & 14.14418 \\
\hline age lefteducation notstated & 4.70178 & & 3.85711 & 1.89 & 0.059 & 0.94184 & 23.47181 \\
\hline age - m edian & 1.00399 & & 0.00412 & 0.97 & 0332 & 099595 & 1.01209 \\
\hline living w ith a partner & 0.45595 & $\star \star \star$ & 0.04833 & -7.41 & 0.000 & 0.37041 & 0.56124 \\
\hline lone parent & 0.45470 & $\star \star \star$ & 0.07023 & -5.10 & 0.000 & 0.33593 & 0.61546 \\
\hline has child aged 0-2 & 0.50928 & $\star \star \star$ & 0.08689 & -3.95 & 0.000 & 036453 & 0.71152 \\
\hline has child aged 5-7 & 0.57937 & $\star \star$ & 0.12381 & -2.55 & 0.011 & 038111 & 0.88076 \\
\hline has child aged 11-15 & 0.78094 & $\star *$ & 0.09762 & -198 & 0.048 & 0.61124 & 099776 \\
\hline youngestchild aged 5-7 & 1.75617 & $\star \star$ & 0.45073 & 2.19 & 0.028 & 1.06194 & 290422 \\
\hline ethnic group black C aribbean & 197941 & $\star \star \star$ & 0.52365 & 2.58 & 0.010 & 117856 & 3.32446 \\
\hline ethnic group black A frican & 3.85712 & $\star \star *$ & 132121 & 3.94 & 0.000 & 197103 & 7.54799 \\
\hline ethnic group Indian & 4.54510 & $\star \star *$ & 1.47019 & 4.68 & 0.000 & 2.41106 & 8.56801 \\
\hline ethnic & 719212 & $\star \star \star$ & 234385 & 6.05 & 0.000 & 3.79714 & 13.62249 \\
\hline $\begin{array}{l}\text { Pakistani/B angladeshi } \\
\text { ethnic group other }\end{array}$ & 3.01356 & $\star \star \star$ & 1.01925 & 326 & 0.001 & 155305 & 5.84757 \\
\hline health index & 0.83799 & $\star * *$ & 0.03603 & -4.11 & 0.000 & 0.77027 & 091168 \\
\hline no long-standing ithess/disability & 0.62536 & $\star \star *$ & 0.06818 & -431 & 0.000 & 0.50504 & 0.77434 \\
\hline English is not first language & 222683 & & 0.96600 & 1.85 & 0.065 & 095155 & 521123 \\
\hline
\end{tabular}




\begin{tabular}{|c|c|c|c|c|c|c|c|}
\hline & O dds & Sig & Std En & $\mathrm{z}$ & $\mathrm{P}>|z|$ & \multicolumn{2}{|c|}{ [Conf. Interval] } \\
\hline speaks only English athom e & 197169 & & 0.87810 & 1.52 & 0.127 & 0.82367 & 4.71983 \\
\hline positive experience of school & 0.65162 & $\star \star \star *$ & 0.05884 & -4.74 & 0.000 & 0.54591 & 0.77779 \\
\hline has problem sw riting in English & 1.96376 & $\star \star \star$ & 021897 & 6.05 & 0.000 & 1.57824 & 2.44345 \\
\hline has problem s spelling in English & 192573 & $\star \star \star$ & 021385 & 5.90 & 0.000 & 154908 & 239397 \\
\hline $\begin{array}{l}\text { has no problem s w ith English or } \\
m \text { aths }\end{array}$ & 0.45496 & $\star * *$ & 0.05399 & -6.64 & 0.000 & 0.36054 & 0.57410 \\
\hline em ployed & 0.33239 & $\star \star *$ & 0.03418 & -10.71 & 0.000 & 027172 & 0.40661 \\
\hline $\begin{array}{l}\text { strongly believe leaming helps get } \\
\text { a job }\end{array}$ & 121945 & ** & 012292 & 1.97 & 0.049 & 1.00084 & 1.48582 \\
\hline $\begin{array}{l}\text { strongly believe leaming } m \text { akes } \\
\text { m ore confident }\end{array}$ & 1.96143 & $\star \star \star$ & 023090 & 5.72 & 0.000 & 155728 & 2.47045 \\
\hline $\begin{array}{l}\text { strongly believe who you know } \\
\text { gets you a job }\end{array}$ & 0.78614 & $\star \star \star$ & 0.06799 & -2.78 & 0.005 & 0.66357 & 0.93137 \\
\hline $\begin{array}{l}\text { strongly disagree getting } \\
\text { qualifications too m uch effort }\end{array}$ & 1.49466 & $\star * *$ & 013899 & 432 & 0.000 & 124562 & 1.79347 \\
\hline em ploym entcom m itm ent index & 1.06673 & $\star \star \star$ & 0.01120 & 6.16 & 0.000 & 1.04502 & 1.08890 \\
\hline LA unem ploym entrate & 090004 & $\star \star \star$ & 0.03229 & -2.94 & 0.003 & 0.83893 & 096561 \\
\hline
\end{tabular}

O m itted categories

literacy test score entry level1

num eracy testscore entry levell

no qualifications

left full-tim e education aged 18+

ethnic group w hite

*** significantat $1 \%$ level

** significantat5\% level 
Table A 2 . 2 Effect of Propensity Score M atching on D ifferences betw een Leamers and $\mathrm{N}$ on-leamers

\begin{tabular}{|c|c|c|c|c|c|c|c|}
\hline V ariable & Sam ple & $\begin{array}{l}\text { M ean } \\
\text { Treated }\end{array}$ & Control & $\div$ bias & $\begin{array}{l}\% \\
\text { reduction } \\
\text { pias| }\end{array}$ & $\begin{array}{l}\text { t-test } \\
t\end{array}$ & $\mathrm{p}>|t|$ \\
\hline \multirow{2}{*}{ literacy test score } & U nm atched & 7.4600 & 10.4550 & -13.0 & -3.80 & 0.16 & \\
\hline & M atched & 7.5044 & 6.9894 & 22 & 82.80 & 0.69 & 0.615 \\
\hline \multirow[t]{2}{*}{ num eracy testscore } & U nm atched & 6.5203 & 6.9854 & -22 & -0.66 & 0.63 & \\
\hline & M atched & 6.5647 & 7.0024 & -21 & 590 & -0.67 & 0.623 \\
\hline \multirow[t]{4}{*}{ highestqualification } & Unm atched & 2.4490 & 2.5908 & -49 & -1.45 & 0.39 & \\
\hline & M atched & 2.4296 & 23823 & 1.6 & 66.60 & 0.69 & 0.616 \\
\hline & Unm atched & 1.5886 & 1.4043 & 209 & 619 & 010 & \\
\hline & M atched & 15603 & 15260 & 39 & 81.40 & 195 & 0.302 \\
\hline \multirow[t]{2}{*}{ age less m edian } & Unm atched & 0.6046 & 2.1670 & -133 & -3.93 & 0.16 & \\
\hline & M atched & 0.6727 & -0.0003 & 5.7 & 56.90 & 1.54 & 0.366 \\
\hline \multirow[t]{2}{*}{ living $w$ ith a partner } & U nm atched & 0.3709 & 0.5887 & -44.7 & -1313 & 0.05 & \\
\hline & M atched & 0.3769 & 03784 & -0.3 & 9930 & -0.46 & 0.724 \\
\hline \multirow[t]{2}{*}{ lone parent } & U nm atched & 0.1169 & 0.1416 & -7.4 & -2.17 & 028 & \\
\hline & M atched & 0.1175 & 0.1307 & -39 & 46.70 & -124 & 0.433 \\
\hline \multirow[t]{2}{*}{ has child aged 0-2 } & U nm atched & 0.0572 & 0.1357 & -26.8 & -7.80 & 0.08 & \\
\hline & M atched & 0.0584 & 0.0623 & -13 & 95.10 & -0.63 & 0.642 \\
\hline \multirow[t]{2}{*}{ has child aged 5-7 } & U nm atched & 0.1126 & 0.1643 & -15.0 & -4.40 & 0.14 & \\
\hline & M atched & 0.1131 & 0.1044 & 25 & 83.30 & 0.77 & 0.583 \\
\hline \multirow[t]{8}{*}{ has child aged 11-15 } & U nm atched & 0.1181 & 0.1941 & -21.0 & -6.15 & 010 & \\
\hline & M atched & 0.1194 & 0.1253 & -1.6 & 9220 & -0.65 & 0.635 \\
\hline & U nm atched & 0.0572 & 0.1357 & -26.8 & -7.80 & 0.08 & \\
\hline & M atched & 0.0584 & 0.0623 & -13 & 9510 & -0.63 & 0.642 \\
\hline & Unm atched & 0.0812 & 0.0865 & -19 & -0.56 & 0.67 & \\
\hline & M atched & 0.0810 & 0.0699 & 4.0 & -110.00 & 126 & 0.427 \\
\hline & Unm atched & 0.1181 & 0.1941 & -21.0 & -615 & 010 & \\
\hline & M atched & 0.1194 & 0.1253 & -1.6 & 9220 & -0.65 & 0.635 \\
\hline \multirow[t]{2}{*}{ ethnic group } & U nm atched & 1.6046 & 12081 & 35.0 & 10.45 & 0.06 & \\
\hline & M atched & 1.5490 & 1.4905 & 52 & 8530 & 2.59 & 0235 \\
\hline \multirow[t]{5}{*}{ health index } & U nm atched & 0.5898 & 0.4724 & 10.4 & 3.07 & 020 & \\
\hline & M atched & 0.5917 & 0.6052 & -12 & 88.50 & -0.40 & 0.759 \\
\hline & Unm atched & 15812 & 1.7486 & -36.0 & -10.65 & 0.06 & \\
\hline & M atched & 15848 & 1.6112 & -5.7 & 8430 & -1.80 & 0.323 \\
\hline & U nm atched & 11445 & 1.0622 & 273 & 8.13 & 0.08 & \\
\hline
\end{tabular}




\begin{tabular}{|c|c|c|c|c|c|c|c|}
\hline V ariable & Sample & $\begin{array}{l}\text { M ean } \\
\text { Treated }\end{array}$ & Control & $\because$ bias & $\begin{array}{l}\% \\
\text { reduction } \\
\text { pias| }\end{array}$ & $\begin{array}{l}t \text {-test } \\
t\end{array}$ & $p>|+|$ \\
\hline & M atched & 1.1363 & 1.1262 & 33 & 87.80 & 1.57 & 0360 \\
\hline & U nm atched & 0.8745 & 0.9438 & -24.3 & -722 & 0.09 & \\
\hline & M atched & 0.8819 & 0.8925 & -3.7 & 84.70 & -1.65 & 0.347 \\
\hline & U nm atched & 1.0369 & 1.0297 & 4.0 & 1.18 & 0.45 & \\
\hline & M atched & 1.0377 & 1.0435 & -33 & 18.40 & -1.00 & 0.501 \\
\hline & Unm atched & 0.4613 & 0.5681 & -21.5 & -6.33 & 010 & \\
\hline & M atched & 0.4623 & 0.4554 & 1.4 & 93.50 & 0.35 & 0.786 \\
\hline & U nm atched & 0.4274 & 0.1632 & 605 & 17.96 & 0.04 & \\
\hline & M atched & 0.4202 & 0.4025 & 41 & 93.30 & 1.49 & 0.376 \\
\hline & U nm atched & 0.5966 & 02876 & 65.4 & 19.30 & 0.03 & \\
\hline & M atched & 0.5905 & 0.5918 & -0.3 & 99.60 & 028 & 0.824 \\
\hline & U nm atched & 0.1476 & 0.4470 & -69.3 & -20.18 & 0.03 & \\
\hline & M atched & 0.1508 & 0.1506 & 0.0 & 100.00 & -025 & 0.845 \\
\hline \multirow[t]{12}{*}{ em ployed } & U nm atched & 0.3370 & 0.5568 & -45.3 & -13.31 & 0.05 & \\
\hline & M atched & 0.3436 & 03626 & -39 & 91.30 & -1.58 & 0.359 \\
\hline & U nm atched & 0.7552 & 0.6503 & 231 & 6.78 & 0.09 & \\
\hline & M atched & 0.7519 & 0.7470 & 11 & 95.40 & 0.56 & 0.675 \\
\hline & U nm atched & 0.8549 & 0.7254 & 322 & 9.40 & 0.07 & \\
\hline & M atched & 0.8536 & 0.8270 & 6.6 & 79.40 & 225 & 0267 \\
\hline & U nm atched & 0.5252 & 0.6043 & -16.0 & -4.71 & 013 & \\
\hline & M atched & 0.5302 & 0.5319 & -0.3 & 97.80 & -0.39 & 0.762 \\
\hline & U nm atched & 0.3844 & 03524 & 6.6 & 1.95 & 0.30 & \\
\hline & M atched & 0.3832 & 0.4016 & -3.8 & 4220 & -1.04 & 0.487 \\
\hline & Unm atched & 16.5580 & 15.6560 & 20.5 & 5.99 & 0.11 & \\
\hline & M atched & 16.5270 & 16.4410 & 19 & 90.50 & 0.83 & 0.558 \\
\hline \multirow[t]{2}{*}{ LA unem ploym entrate } & U nm atched & 2.5781 & 2.6088 & -2.5 & -0.73 & 0.60 & \\
\hline & M atched & 25731 & 25905 & -1.4 & 4310 & -0.30 & 0.816 \\
\hline
\end{tabular}




\section{A ppendix $3: N$ ew courses and progression}

Table A 3.1 Factors affecting starting a new course atW ave 2

D ependentvariable:w hether started a new course atw 2 (1 yes, 0 no)

Logitestim ates

Log pseudo-likelihood $=-367.88077$

w 2new c

tested num eracy com petence

Entry Level2

Entry Level3

Level1

Level2 or higher

no full test

interaction Entry Level2

Entry Level3

Level1

Level2 orhigher

no fullitest

highestqualification held

below level1

Level1

Level2

Level3

Level4

age leftschool

$17-18$

19 and over

children

one

two

three orm ore

interaction one

two

three orm ore

change in health, W 1-W 2

no change

im proved

econom ic activity, $\mathrm{W} 1$

unem ployed

full-tim e education

other
Robust

Coef. Std.Err. z $\quad \mathrm{P}>\mathrm{z} \mid$

[95\% Conf. Interval]
$\begin{array}{lrr}\mathrm{N} \text { um berofobs } & = & 614 \\ \mathrm{~W} \text { ald chi2 }(44) & = & 78.07 \\ \text { Prob > chi2 } & = & 0.0012 \\ \text { Pseudo R2 } & = & 0.1309\end{array}$

\begin{tabular}{|c|c|c|c|c|c|}
\hline 0.046415 & 0339078 & 0.14 & 0.891 & -0.61817 & 0.710994 \\
\hline 0207458 & 0.514141 & 0.4 & 0.687 & -0.80024 & 1215156 \\
\hline 864281 & 0.648409 & 133 & 0.183 & -0.40658 & 2135138 \\
\hline .028415 & 0.680351 & 1.51 & 0.131 & -0.30505 & 2361879 \\
\hline 056222 & 0942426 & 1.12 & 0262 & -0.7909 & 2903344 \\
\hline 186313 & 0.471718 & 039 & 0.693 & -0.73824 & 1110864 \\
\hline .83123 & 0.982282 & 1.86 & 0.062 & -0.09401 & 3.756467 \\
\hline 1196 & 1236482 & -0.1 & 0923 & -2.54306 & 2303859 \\
\hline .79202 & 0971412 & -0.82 & 0.415 & -2.69596 & 1111908 \\
\hline .76518 & 1188891 & -0.64 & 0.52 & -3.09536 & 1.565007 \\
\hline 632245 & 0.443482 & 1.43 & 0.154 & -023696 & 1.501453 \\
\hline .0154 & 0266525 & -0.06 & 0954 & -0.53778 & 0.506979 \\
\hline .05409 & 0360411 & -0.15 & 0.881 & -0.76049 & 0.6523 \\
\hline 182458 & 0.494134 & 239 & 0.017 & 0213974 & 2.150942 \\
\hline .06208 & 0.640056 & -0.1 & 0.923 & -131657 & 1192401 \\
\hline 135273 & 0.308361 & 0.44 & 0.661 & -0.4691 & 0.73965 \\
\hline 035967 & 0.36503 & 2.84 & 0.005 & 0.320522 & 1.751413 \\
\hline 63296 & 0.403774 & 1.57 & 0.117 & -0.15842 & 1.424343 \\
\hline 14163 & 0.444093 & -0.32 & 0.75 & -1.01204 & 0.728775 \\
\hline .60067 & 0.55685 & -1.08 & 0281 & -1.69207 & 0.490736 \\
\hline 98545 & 0.573826 & -1.72 & 0.086 & -211013 & 0.139226 \\
\hline 353661 & 0.717769 & 0.49 & 0.622 & -1.05314 & 1.760464 \\
\hline 350594 & 0.762098 & 0.46 & 0.645 & -1.14309 & 1.844278 \\
\hline 310869 & 0274423 & 1.13 & 0257 & -022699 & 0.848727 \\
\hline 907424 & 0.39312 & 231 & 0.021 & 0.136923 & 1.677924 \\
\hline 24442 & 0348933 & -0.7 & 0.484 & -0.92832 & 0.439475 \\
\hline 83578 & 0.411398 & -2.03 & 0.042 & -1.6421 & -0.02945 \\
\hline 82068 & 0259797 & 1.09 & 0278 & -022713 & 0.791262 \\
\hline
\end{tabular}


highestqualification studying, w 1

$\begin{array}{ll} & \text { Level1 } \\ & \text { Level2 } \\ & \text { Level3 orhigher } \\ \text { interaction } & \text { Level1 } \\ & \text { Level2 } \\ & \text { Level3 orhigher }\end{array}$

age (ln)

em ploym entcom m itm ent, index interaction

localunem ploym entrate

interaction

course qualification, W 1 basic skills-specific com pleted a W 1 course by W 2

dropped outof a W 1 course

interaction

continued W 1 course atW 2

constant

$\begin{array}{llllll}-0.50427 & 0.415882 & -121 & 0.225 & -1.31938 & 0.310848 \\ -0.97249 & 0.394808 & -2.46 & 0.014 & -1.7463 & -0.19868 \\ 0.217759 & 0.583003 & 0.37 & 0.709 & -0.92491 & 1.360423 \\ 1.738277 & 0.562939 & 3.09 & 0.002 & 0.634937 & 2.841617 \\ 129861 & 0.529256 & 2.45 & 0.014 & 0.261287 & 2.335933 \\ 1.001691 & 0.762052 & 1.31 & 0.189 & -0.4919 & 2.495285 \\ -0.71356 & 0.352928 & -2.02 & 0.043 & -1.40529 & -0.02184 \\ 0.549924 & 0.312756 & 1.76 & 0.079 & -0.06307 & 1.162913 \\ -0.91361 & 0.381719 & -2.39 & 0.017 & -1.66177 & -0.16546 \\ 0.258425 & 0.333675 & 0.77 & 0.439 & -0.39557 & 0.912415 \\ -0.74616 & 0.472381 & -1.58 & 0.114 & -1.67201 & 0.17969 \\ 0.591396 & 0.323997 & 1.83 & 0.068 & -0.04363 & 1226417 \\ 0.488641 & 0.266916 & 1.83 & 0.067 & -0.0345 & 1.011786 \\ -0.75134 & 0.366935 & -2.05 & 0.041 & -1.47052 & -0.03216 \\ 1.663283 & 0.553537 & 3 & 0.003 & 0.57837 & 2.748196 \\ 2.331843 & 1.130529 & 2.06 & 0.039 & 0.116046 & 4.54764 \\ -0.45796 & 1.701119 & -027 & 0.788 & -3.79209 & 2.876168\end{array}$


Table A 32 Factors affecting starting a new higher-level course atW ave 2

D ependentvariable: w hether started a new higher-level course atW 2 (1 yes, 0 no)

Logitestim ates

Log pseudo-likelihood $=-367.88077$

w 2 progn2

tested literacy com petence

Entry Level2
Entry Level3
Level1
no full test
Entry Level2
Entry Level3
Level1
no full test

tested num eracy com petence

Entry Level2

Entry Level3

Level1

Level2 orhigher

interaction Entry Level2

Entry Level3

Level1

Level2 orhigher

highestqualification held

below level1
Level1
Level2
Level3
Level4

age leftschool

17-18

19 and over

ethnicity

B lack or B lack British - Caribbean

B lack or B lack B ritish - A frican

A sian orA sian B ritish - Indian

A sian or A sian B ritish - Pakistani or

other

children

$\begin{array}{ll} & \text { one } \\ & \text { two } \\ & \text { three orm ore } \\ \text { interaction } & \text { one } \\ & \text { two } \\ & \text { three orm ore }\end{array}$

Robust

Coef.

Sto. En

0935457

2.802372

1.770093

1980247

$-0.43317$

$-320583$

$-1.59468$

0235685

$-0.76539$

$-0.37946$

0.326163

0.501912

1.828741

2190562

0.435841

$-0.02976$

0.686751

0.541701

0.648482

2.03161

$-0.12959$

0328685

09569

$-021041$

0.5404

2129075

$-0.1418$

0186574

$-0.7151$

$-0.46065$

$-196574$

$-0.09015$

$-029572$

2.175724
$\mathrm{Num}$ berofobs $=570$

$\mathrm{W}$ ald chi2 (69) = 13934

Prob $>$ chi2 $=0.0000$

Pseudo R2 = 03176

$\begin{array}{ll}0.898327 & 1 \\ 0.930997 & 3 \\ 0.967797 & 1.8 \\ 0.907975 & 22 \\ 1.104794 & -0 \\ 1215674 & -3 \\ 1173964 & -1 \\ 1.431824 & 02\end{array}$

0298

$\begin{array}{lll}0.003 & 0.977652 & 4.627092\end{array}$

$0.067 \quad-0.12676 \quad 3.666941$

$0.029 \quad 0200649 \quad 3.759845$

$0.695 \quad-2.59853 \quad 1.732186$

$0.008 \quad-5.58851 \quad-0.82315$

$\begin{array}{lll}0.174 & -3.89561 & 0.706249\end{array}$

$\begin{array}{lll}0.869 & -2.57064 \quad 3.042007\end{array}$

$\begin{array}{llllll}0.591729 & -1 & 0.196 & -1.92516 & 0.394374\end{array}$

$\begin{array}{lllll}0.828641 & -0 & 0.647 & -2.00356 & 1244652\end{array}$

$\begin{array}{lllll}1.008808 & 0.3 & 0.746 & -1.65107 & 2.30339\end{array}$

$\begin{array}{lllll}0.917345 & 0.6 & 0.584 & -129605 & 2299875\end{array}$

$\begin{array}{lllll}0.762618 & 2.4 & 0.016 & 0.334038 & 3.323445\end{array}$

$\begin{array}{lllll}1.419081 & 1.5 & 0.123 & -0.59079 & 4.97191\end{array}$

$\begin{array}{lllll}2.414886 & 02 & 0.857 & -429725 & 5.168931\end{array}$

$\begin{array}{lllll}1284957 & -0 & 0.982 & -2.54823 & 2.488712\end{array}$

$\begin{array}{lllll}0.633303 & 11 & 0278 & -0.5545 & 1.928002\end{array}$

$\begin{array}{lllll}0.399575 & 1.4 & 0.175 & -024145 & 1.324854\end{array}$

$\begin{array}{lllll}0.496692 & 13 & 0.192 & -0.32502 & 1.62198\end{array}$

$\begin{array}{lllll}0.636341 & 32 & 0.001 & 0.784405 & 3278816\end{array}$

$\begin{array}{llllll}1.007451 & -0 & 0.898 & -2.10416 & 1.844977\end{array}$

$\begin{array}{lllll}0.424599 & 0.8 & 0.439 & -0.50351 & 1.160883\end{array}$

$\begin{array}{lllll}0.46292 & 21 & 0.039 & 0.049594 & 1.864206\end{array}$

$\begin{array}{lllll}1.454826 & -0 & 0.885 & -3.06182 & 2.640996\end{array}$

$\begin{array}{lllll}1.035801 & 0.5 & 0.602 & -1.48973 & 2.570532\end{array}$

$\begin{array}{lllll}0.743111 & 2.9 & 0.004 & 0.672605 & 3.585545\end{array}$

$\begin{array}{lllll}0.660416 & -0 & 0.83 & -1.43619 & 1.152589\end{array}$

$\begin{array}{lllll}1.990702 & 01 & 0.925 & -3.71513 & 4.088278\end{array}$

$\begin{array}{llllll}0.856518 & -1 & 0.404 & -2.39384 & 0.963648\end{array}$

$\begin{array}{llllll}0.6531 & -1 & 0.481 & -1.7407 & 0.819401\end{array}$

$\begin{array}{llllll}0.748574 & -3 & 0.009 & -3.43292 & -0.49856\end{array}$

$\begin{array}{lllll}0.972739 & -0 & 0.926 & -1.99668 & 1.816386\end{array}$

$\begin{array}{llllll}1233832 & -0 & 0.811 & -2.71399 & 2.122547\end{array}$

$\begin{array}{lllll}120971 & 1.8 & 0.072 & -0.19526 & 4.546712\end{array}$ 
w 2 progn2

change in health, W 1-W 2

no change

im proved

interaction no change

im proved

econom ic activity, $\mathrm{W} 1$

unem ployed

full-tim e education

other

highestqualification studying, W 1

Level1

Level2

Level3 orhigher

interaction

Level1

Level2

Level3 orhigher

positive experience of school

ferm ale

lives $w$ ith a partner

health index, W 1

interaction

health index, w 2

interaction

very happy $w$ ith life

interaction

em ploym entcom $m$ itm ent, index

interaction

reason fordoing $m$ ain course ow $n$ satisfaction

course inchuded literacy, W 1

interaction

course included num eracy, W 1

interaction

com pleted a W 1 course by W 2

interaction

dropped outof a W 1 course

interaction

gained qualification by W 2

continued W 1 course atW 2

constant

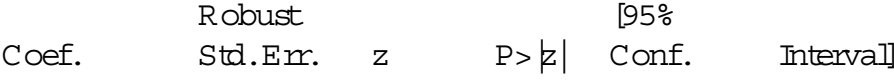

$\begin{array}{llllll}1.936722 & 1.328576 & 1.5 & 0.145 & -0.66724 & 4.540683 \\ 4.429135 & 2.32342 & 1.9 & 0.057 & -0.12468 & 8.982954 \\ -3.97839 & 1.766861 & -2 & 0.024 & -7.44137 & -0.5154 \\ -6.14695 & 2.964027 & -2 & 0.038 & -11.9563 & -0.33756 \\ & & & & & \\ -0.00822 & 0.52339 & -0 & 0.987 & -1.03405 & 1.017604 \\ 0.44892 & 0.674129 & 0.7 & 0.505 & -0.87235 & 1.770188 \\ 1.316662 & 0.401303 & 3.3 & 0.001 & 0.530122 & 2.103202 \\ & & & & & \\ 0.680809 & 0.550146 & 12 & 0.216 & -0.39746 & 1.759074 \\ -0.72512 & 0.580904 & -1 & 0.212 & -1.86367 & 0.413432 \\ -2.55654 & 0.897423 & -3 & 0.004 & -4.31545 & -0.79762 \\ 0.052887 & 0.75584 & 0.1 & 0.944 & -1.42853 & 1.534305 \\ -1.39019 & 0.817245 & -2 & 0.089 & -2.99196 & 0.11579 \\ -0.77881 & 1.331219 & -1 & 0.559 & -3.38795 & 1.830335 \\ -0.78143 & 0.344265 & -2 & 0.023 & -1.45618 & -0.10669 \\ -0.58955 & 0.317293 & -2 & 0.063 & -121143 & 0.032334 \\ 0.671719 & 0.361445 & 1.9 & 0.063 & -0.0367 & 1.380138 \\ -42355 & 1.38187 & -3 & 0.002 & -6.94391 & -1.52708 \\ 4.956057 & 1.807545 & 2.7 & 0.006 & 1.413334 & 8.498781 \\ 2.310612 & 1.366038 & 1.7 & 0.091 & -0.36677 & 4.987998 \\ -3.66567 & 1.83732 & -2 & 0.046 & -726675 & -0.06459 \\ -0.3622 & 0.499457 & -1 & 0.468 & -1.34112 & 0.616716 \\ 1.160184 & 0.664738 & 1.8 & 0.081 & -0.14268 & 2.463046 \\ 2.213722 & 0.649624 & 3.4 & 0.001 & 0.940483 & 3.486961 \\ -2.49953 & 0.76711 & -3 & 0.001 & -4.00304 & -0.99602 \\ -1.04507 & 0.344522 & -3 & 0.002 & -1.72032 & -0.36982 \\ -0.30188 & 0.540053 & -1 & 0.576 & -1.36036 & 0.756605 \\ -1.58789 & 0.852249 & -2 & 0.062 & -325827 & 0.082483 \\ 0.733521 & 0.515858 & 1.4 & 0.155 & -0.27754 & 1.744584 \\ -134616 & 0.696145 & -2 & 0.053 & -2.71058 & 0.018259 \\ -0.08963 & 0.613403 & -0 & 0.884 & -129187 & 1.112621 \\ 1.44334 & 0.824215 & 1.8 & 0.08 & -0.17209 & 3.05877 \\ -0.58307 & 0.56492 & -1 & 0.302 & -1.6903 & 0.524148 \\ 2.530067 & 0.845807 & 3 & 0.003 & 0.872315 & 4.187819 \\ 0.798089 & 0.445116 & 1.8 & 0.073 & -0.07432 & 1.670501 \\ 11.7137 & 3.163585 & 3.7 & 0 & 5.513184 & 17.91421 \\ -10.4255 & 2.63493 & -4 & 0 & -15.5899 & -526116\end{array}$


Table A 3.3 Factors affecting starting a new course atW ave 3

D ependentvariable: w hether started a new course atw 3 (1 yes, 0 no)

Logitestim ates

Log pseudo-likelihood $=-367.88077$

w 3new c

tested num eracy com petence

Entry Level2

Entry Level3

Level1

Level2 orhigher

no full test

highest qualification held

below level1

Level1

Level2

Level3

Level4

interaction below levell

Level1

Level2

Level3

Level4

age leftschool

$17-18$

19 and over

ethnicity

B lack or B lack British - Caribbean

$B$ lack or B lack B ritish - A frican

A sian orA sian B ritish - Indian

A sian or A sian B ritish - Pakistani or

other

interaction

B lack or B lack British - Caribbean

$B$ lack or B lack B ritish - A frican

A sian orA sian B ritish - Indian

A sian or A sian B ritish - Pakistani or

other

children

one

two

three orm ore
Robust

Coef.

Sta.Err.

0.002874

0.877598

$-0.10306$

0168445

0.893637

119566

0178839

0.695421

1.400679

0.071934

$-2.67429$

$-0.01266$

$-0.02766$

0.841426

$-1.72218$

$-0.52277$

1.051152

$-0.04145$

2.587661

$-0.82386$

0.042258

0276907

1933755

-1 96519

3.078334

1.591338

$-0.19141$

$-0.75039$

$-0.53992$

$-1.01696$

$\begin{array}{lllll}0.281689 & 0.01 & 0.992 & -0.54923 & 0.554974 \\ 0.539616 & 1.63 & 0.104 & -0.18003 & 1.935226 \\ 0.737016 & -0.14 & 0.889 & -1.54758 & 1.34147 \\ 0.554342 & 0.3 & 0.761 & -0.91804 & 1254935 \\ 0.521636 & 1.71 & 0.087 & -0.12875 & 1.916025 \\ & & & & \\ 0.553941 & 2.16 & 0.031 & 0.109957 & 2.281364 \\ 0.358244 & 0.5 & 0.618 & -0.52331 & 0.880985 \\ 0.47168 & 1.47 & 0.14 & -0.22905 & 1.619896 \\ 0.49557 & 2.83 & 0.005 & 0.429381 & 2.371977 \\ 0.68916 & 0.1 & 0.917 & -12788 & 1.422662 \\ 1.016637 & -2.63 & 0.009 & -4.66686 & -0.68172 \\ 0.683248 & -0.02 & 0.985 & -1.3518 & 1.32648 \\ 0.749457 & -0.04 & 0.971 & -1.49656 & 1.441252 \\ 1.179074 & 0.71 & 0.475 & -1.46952 & 3.152369 \\ 1.243504 & -1.38 & 0.166 & -4.1594 & 0.715046 \\ 0.338037 & -1.55 & 0.122 & -1.18531 & 0.139771 \\ 0.409862 & 2.56 & 0.01 & 0.247837 & 1.854466\end{array}$

$\begin{array}{lllll}0.76941 & -0.05 & 0.957 & -1.54946 & 1.466567\end{array}$

$\begin{array}{lllll}0.971142 & 2.66 & 0.008 & 0.684258 & 4.491064\end{array}$

$\begin{array}{lllll}0.725151 & -1.14 & 0256 & -224513 & 0.597407\end{array}$

$\begin{array}{lllll}0.58435 & 0.07 & 0.942 & -1.10305 & 1.187562\end{array}$

$\begin{array}{lllll}1.056375 & 026 & 0.793 & -1.79355 & 2347364\end{array}$

$\begin{array}{lllll}1.515315 & 128 & 0202 & -1.03621 & 4.903717\end{array}$

$\begin{array}{lllll}1.810228 & -1.09 & 0278 & -5.51317 & 1.582791\end{array}$

$\begin{array}{lllll}1.449788 & 2.12 & 0.034 & 0236801 & 5.919867\end{array}$

$\begin{array}{lllll}1.071341 & 1.49 & 0.137 & -0.50845 & 3.691129\end{array}$

$\begin{array}{lllll}216903 & -0.09 & 0.93 & -4.44263 & 4.059812\end{array}$

$\begin{array}{lllll}0.337806 & -222 & 0.026 & -1.41247 & -0.0883\end{array}$

$\begin{array}{lllll}0.437225 & -123 & 0217 & -139687 & 0.317023\end{array}$

$\begin{array}{lllll}0.510816 & -1.99 & 0.046 & -2.01815 & -0.01578\end{array}$ 
w 3new c

econom ic activity, W 1

unem ployed

full-tim e education

other

interaction unem ployed

full-tim e education

other

econom ic activity, W 2

unem ployed

full-tim e education

other

interaction unem ployed

full-tim e education

other

positive experience of school

interaction

health index, W 2

reason fordoing $m$ ain course help children m ore ow $n$ satisfaction

interaction ow $n$ satisfaction did higher-level course atw 2 interaction

com pleted a W 1 course by W 2

interaction

dropped outofa W 1 course

interaction

gained qualification by W 3

continued W 1 course atW 3

constant $\begin{array}{llllll} & \text { Robust } & & & {[95 \%} & \\ \text { Coef. } & \text { Std.Err. } & z & P>k \mid & \text { Conf. } & \text { Interval] }\end{array}$

$\begin{array}{llllll}0.075765 & 0.547481 & 0.14 & 0.89 & -0.99728 & 1.148808 \\ -0.60163 & 0.7388 & -0.81 & 0.415 & -2.04965 & 0.846393 \\ 0.435889 & 0.501069 & 0.87 & 0.384 & -0.54619 & 1.417965 \\ 2238184 & 1.628365 & 1.37 & 0.169 & -0.95335 & 5.42972 \\ 3.825175 & 2.103453 & 1.82 & 0.069 & -0.29752 & 7.947867 \\ 4.142181 & 1.890218 & 2.19 & 0.028 & 0.437422 & 7.84694\end{array}$

$\begin{array}{llllll}1.7188 & 0.580659 & 2.96 & 0.003 & 0.580729 & 2.85687\end{array}$

$\begin{array}{llllll}1.806144 & 0.649304 & 2.78 & 0.005 & 0.533532 & 3.078756\end{array}$

$\begin{array}{llllll}0.13129 & 0.499407 & 026 & 0.793 & -0.84753 & 1.11011\end{array}$

$\begin{array}{lllllll}-597321 & 1.926029 & -31 & 0.002 & -9.74816 & -2.19826\end{array}$

$\begin{array}{llllll}-5.65155 & 2.043843 & -2.77 & 0.006 & -9.65741 & -1.64569\end{array}$

$\begin{array}{llllll}-4.77447 & 1.928238 & -2.48 & 0.013 & -8.55375 & -0.9952\end{array}$

$\begin{array}{llllll}-0.65195 & 0292928 & -223 & 0.026 & -122608 & -0.07782\end{array}$

$\begin{array}{llllll}1.037548 & 0.568732 & 1.82 & 0.068 & -0.07715 & 2152242\end{array}$

$\begin{array}{llllll}-0.72384 & 0271043 & -2.67 & 0.008 & -125508 & -0.19261\end{array}$

$\begin{array}{llllll}0.598805 & 0.314992 & 19 & 0.057 & -0.01857 & 1216179\end{array}$

$\begin{array}{llllll}0220321 & 0298252 & 0.74 & 0.46 & -0.36424 & 0.804883\end{array}$

$\begin{array}{lllllll}1.650264 & 0.634707 & 2.6 & 0.009 & 0.406261 & 2.894268\end{array}$

$\begin{array}{llllll}0.531322 & 0.350883 & 1.51 & 0.13 & -0.1564 & 121904\end{array}$

$\begin{array}{llllll}-127089 & 0.729936 & -1.74 & 0.082 & -2.70154 & 0.159756\end{array}$

$\begin{array}{lllllll}0280477 & 0283259 & 0.99 & 0.322 & -02747 & 0.835655\end{array}$

$\begin{array}{llllll}1.448694 & 0.736045 & 1.97 & 0.049 & 0.006071 & 2.891316\end{array}$

$\begin{array}{llllll}-0.73022 & 0.351674 & -2.08 & 0.038 & -1.41949 & -0.04095\end{array}$

$\begin{array}{llllll}2.518062 & 0.98001 & 2.57 & 0.01 & 0.597278 & 4.438847\end{array}$

$\begin{array}{lllllll}1111724 & 0.423223 & 2.63 & 0.009 & 0282223 & 1.941226\end{array}$

$\begin{array}{llllll}-124978 & 0.824429 & -1.52 & 0.13 & -2.86563 & 0.366075\end{array}$

$\begin{array}{llllll}-1.40907 & 0.48875 & -2.88 & 0.004 & -2.367 & -0.45113\end{array}$ 
Table A 3 .4 Factors affecting starting a new higher-level course atW ave 3

D ependentvariable: w hether started a new higher-level course atW 3 (1 yes, 0 no)

Logitestim ates

Log pseudo-likelihood $=-367.88077$

w 13prgn2

tested literacy com petence

Entry Level2

Entry Level3

Level1

no full test

tested num eracy com petence

Entry Level2

Entry Level3

Level1

Level2 orhigher

interaction Entry Level3

highestqualification held

below level1
Level1
Level2
Level3
Level4

age leftschool

$17-18$

19 and over

interaction 17-18

19 and over
Coef.

Robust

0.8734795
1241925
1.782667
0.4763859

0.6057316

0.8905354

$-0.3492088$

01948323

1924228

$-01196533$

$-1.199347$

$-0.5851468$

01666097

$-1.59445$

0.1428077

0.7592209

$-1.854577$

2.643234

ethnicity

B lack or B lack B ritish - C aribbean and other'

\section{B lack orB lack B ritish - A frican 0253258}

A sian orA sian B ritish - Indian $\quad 1.452786$

A sian or A sian B ritish - Pakistanior

other

2.023496

0.8941383

children

$\begin{array}{cl} & \text { one } \\ & \text { tw o } \\ \text { three orm ore } & \\ \text { interaction } & \text { one } \\ & \text { tw o } \\ \text { three orm ore } & \\ \text { change in health, W 1-W } 3 \\ \text { no change } \\ \text { in proved } \\ \text { interaction } \quad \text { no change } \\ & \text { im proved }\end{array}$

$-0.5362123$

0.7795389

$-1.639256$

3.642352

03404391

1.781373

$-0.6854035$

$-0.7604845$

3.054231

5.763938

$\begin{array}{ll}0.642609 & 1.36 \\ 0.728284 & 1.71 \\ 0.736005 & 2.42 \\ 0.932948 & 0.51\end{array}$

$0.478519 \quad 127$

$0.686305 \quad 13$

$0.819955-0.43$

$0.808689 \quad 024$

$0.857446 \quad 224$

0.53644

$-022$

$0.482958-2.48$

$0.526835-1.11$

$0.779847 \quad 021$

$1271042-125$

$0.519491 \quad 027$

$0.537216 \quad 1.41$

$1271073-1.46$

$1.452811 \quad 1.82$

$\begin{array}{ll}1.601736 & 0.16 \\ 0.970558 & 1.5 \\ 1.000971 & 2.02 \\ 0.870595 & 1.03 \\ & \\ 0.645687 & -0.83 \\ 0.564006 & 1.38 \\ 1.043467 & -1.57 \\ 1.490585 & 2.44 \\ 1.4306 & 024 \\ 1.44019 & 124 \\ 0.744442 & -0.92 \\ 0.838866 & -0.91 \\ 1.699767 & 1.8 \\ 2.129148 & 2.71\end{array}$

0.87

0.134

$-2.886086$

$-0.4494731$

0.043

0.0616287

3355045

0.304

$-0.8121958$

3.985363

2.600472

\subsection{6}

$-1.801736$

0.729312

0.167

0.116

$-0.3258916$

1.884969

0.015

0.812

$-3.684414$

0.405903

0.7208595

6.563844

0216

$-2.463485$

3.144364

$-1.041348$

4.604094

$\begin{array}{lll}0.357 & -2.144482 & 0.773675\end{array}$

$0365-2.404632$

0.883664

$0.072-02772515$

6385713

$0.007 \quad 1.590885$

9.936991 
econom ic activity, $\mathrm{W} 1$

unem ployed

full-tim e education

other

interaction

unem ployed

full-tim e education

other

highestqualification studying, w 1

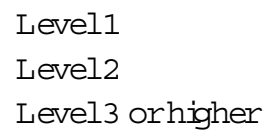

English a subsequent language

age (n)

fem ale

health index, W 3

interaction

self-assessed, problem s w ith literacy

interaction

self-assessed, problem sw ith num eracy

interaction

localunem ploym entrate

interaction

course inchided num eracy, W 1

course $w$ as for a vocationalqualification, $\mathrm{W} 1$

continued W 1 course atW 2

did higher-level course atW 2

com pleted a W 1 course by W 2

dropped outofa W 1 course

dropped out of a W 2 course

gained qualification by $\mathrm{W} 3$

continued W 1 course atW 3

constant

0.5063395
1.023966
0.5177062
-3.059541
-2.212855
-3.118559
-1.826172
-2.060224
-3.697758
-1.821834
-1260685
0.8763517
-0.9857836
2.437542
-02374877
-2.335477
0.0356121
-1.935764
0.1734724
2.289547
-1.027344
1.350164
1.032029
0.8193808
1.020644
-0.9792234
-1.352859
2.651421
-4.436492
1.747766

0.610685

0.716439

$0.573431 \quad 0.9$

$1.589599-1.92$

1240251

$-1.78$

1291163

$-2.42$

$0.600285 \quad-3.04$

$0.506762-4.07$

$0.91642 \quad-4.04$

$0.892977 \quad-2.04$

$0.523858-2.41$

$0.340051 \quad 2.58$

0.52868

$-1.86$

$1271667 \quad 192$

0.407523

$-0.58$

1.178689

0366659

0.980192

$-198$

01

$-1.97$

0.363811

0.48

$0.902768 \quad 2.54$

0.435491

$-2.36$

$0.492296 \quad 2.74$

$0.443138 \quad 2.33$

$0399056 \quad 2.05$

$0.468062 \quad 218$

$0.550717-1.78$

$0.681749-1.98$

$0.715818 \quad 3.7$

2.009656

$-221$

$2.045369 \quad 0.85$
0.407

0.153

0367

0.054

0.074

0.016

$-0.6905806$

$-0.3802278$

$-0.6061973$

$-6175097$

$-4.643702$

$-5.649192$

$0.002 \quad-3.002708$

$0 \quad-3.05346$

$-5.493907$

0.041

$-3.572037$

$-2287427$

02098635

$0.062 \quad-2.021978$

$0.055-0.054879$

$0.56 \quad-1.036219$

$0.048-4.645665$

0.923

0.048

$-0.6830258$

$-3.856904$

$-0.5395838$

0.5201532

0.011

0.018

$-1.88089$

0385281

$0.02 \quad 0.1634954$

$0.04 \quad 0.0372451$

$0.029 \quad 0.1032598$

0.1032598

$0.047-2.689064$

1248444

0

0.027

$-8375345$

$0393-2261084$
1.70326

2.42816

1.64161

0.056015

0217992

$-0.58793$

$-0.64963$

$-1.06699$

- 190161

$-0.07163$

$-023394$

1.54284

0.050411

4.929963

0.561243

$-0.02529$

0.75425

$-0.01462$

0.886529

4.05894

$-0.1738$

2315048

1.900562

1.601516

1.938028

0.100163

$-0.01666$

4.054397

$-0.49764$

5.756616

a O m itted:predicts faihure perfectly 


\section{A ppendix 4}

Table A $4.1 \mathrm{~W}$ ave 3 outcom es

\begin{tabular}{|c|c|c|c|c|c|c|c|c|}
\hline Changes betw een $\mathrm{W}$ ave 1 and $\mathrm{W}$ ave 3 & $\begin{array}{l}\text { unm atche } \\
\text { leamers } \\
\text { value }\end{array}$ & $\begin{array}{l}\text { non- } \\
\text { leamers } \\
\text { value } \\
\end{array}$ & $\begin{array}{l}m \text { atched } \\
\text { leamers } \\
\text { value }\end{array}$ & $\begin{array}{l}\text { non- } \\
\text { leamers } \\
\text { value }\end{array}$ & difference & $\begin{array}{l}\text { Signifi- } \\
\text { cant }\end{array}$ & No of ob & $\begin{array}{l}\text { ations } \\
\text { non- } \\
\text { leamers }\end{array}$ \\
\hline $\begin{array}{l}\text { Labourm arketand w ork } \\
\text { change in employm ent status (net increase/decrease in } \\
\text { proportion of sam ple) }\end{array}$ & $5.6 \%$ & $-1.8 \%$ & $53 \%$ & $3.8 \%$ & $1.4 \%$ & & 623 & 616 \\
\hline change in take hom e pay (non-em ployed=0) & $£ 575$ & $£ 1,339$ & $£ 558$ & $-£ 713$ & $£ 1,272$ & ** & 590 & 587 \\
\hline change in em ploym entcom m itm ent (scale -19 to +19 ) & -2.6 & -2.5 & -2.6 & -3 & 0.4 & & 611 & 578 \\
\hline change in satisfaction $w$ ith pay (scale -4 to +4 ) & 01 & 0 & 0.1 & 01 & 0 & & 201 & 285 \\
\hline higher satisfaction w ith pay (proportion reporting) & $27.4 \%$ & $22.5 \%$ & $271 \%$ & $253 \%$ & $1.8 \%$ & & 201 & 285 \\
\hline low er satisfaction $w$ ith pay (proportion reporting) & $28.4 \%$ & $26.0 \%$ & $28.6 \%$ & $312 \%$ & $-2.5 \%$ & & 201 & 285 \\
\hline $\begin{array}{l}\text { change in pay satisfaction (proportion in proving less } \\
\text { proportion w orsening) }\end{array}$ & $-01 \%$ & $-3.6 \%$ & $-1.5 \%$ & $-5.9 \%$ & $43 \%$ & & 201 & 285 \\
\hline change in satisfaction $w$ ith job security (scale -4 to +4 ) & 0 & -01 & -01 & -02 & 01 & & 201 & 285 \\
\hline satisfaction w ith job security increased (proportion reporting) & $22.5 \%$ & $201 \%$ & $23.0 \%$ & $202 \%$ & $2.8 \%$ & & 258 & 323 \\
\hline satisfaction w ith job security decreased (proportion reporting) & $221 \%$ & $23.8 \%$ & $229 \%$ & $26.0 \%$ & $-31 \%$ & & 258 & 323 \\
\hline $\begin{array}{l}\text { change in satisfaction with job security (proportion increased less } \\
\text { proportion decreased) }\end{array}$ & $0.4 \%$ & $-3.7 \%$ & $0.0 \%$ & $-59 \%$ & $59 \%$ & & 258 & 323 \\
\hline change in satisfaction w ith prom otion prospects (scale -4 to + & -01 & -01 & -01 & -0.4 & 0.3 & ** & 201 & 285 \\
\hline
\end{tabular}




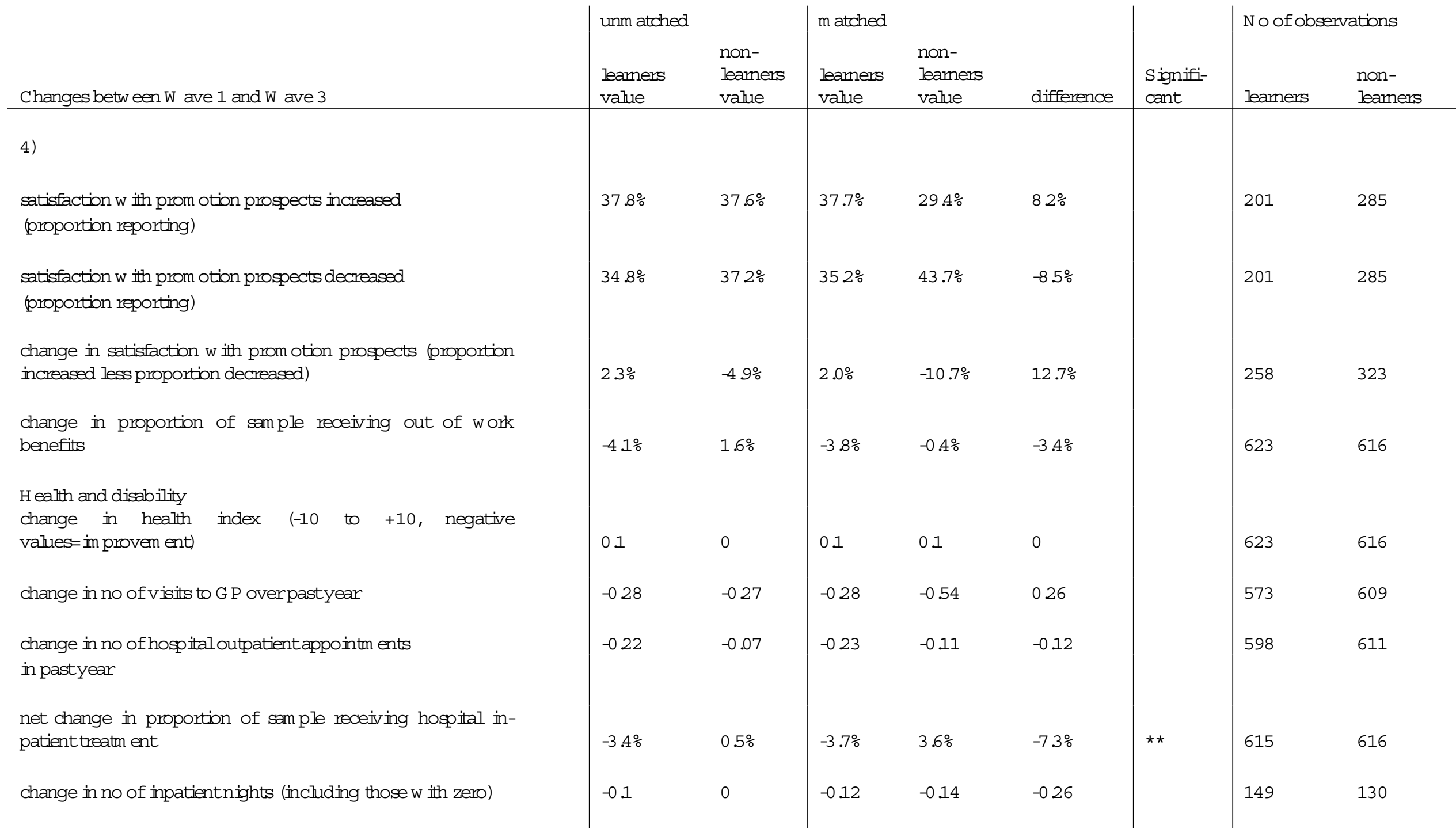




\begin{tabular}{|c|c|c|c|c|c|c|c|c|}
\hline Changes betw een $\mathrm{W}$ ave 1 and $\mathrm{W}$ ave 3 & $\begin{array}{l}\text { unm atche } \\
\text { leamers } \\
\text { value }\end{array}$ & $\begin{array}{l}\text { non- } \\
\text { leamers } \\
\text { value }\end{array}$ & $\begin{array}{l}m \text { atched } \\
\text { leamers } \\
\text { value }\end{array}$ & $\begin{array}{l}\text { non- } \\
\text { leamers } \\
\text { value } \\
\end{array}$ & difference & $\begin{array}{l}\text { Signifi- } \\
\text { cant }\end{array}$ & No of ob & $\begin{array}{l}\text { non- } \\
\text { leamers }\end{array}$ \\
\hline $\begin{array}{l}\text { change in long-standing ilhness ordisability } \\
\text { (proportion developing illness/disability less proportion no longer } \\
\text { having) }\end{array}$ & $-22 \%$ & $-5.7 \%$ & $-2.6 \%$ & $-02 \%$ & $-2.4 \%$ & & 623 & 616 \\
\hline w orse health (proportion reporting) & $185 \%$ & $16.7 \%$ & $18.6 \%$ & $20.0 \%$ & $-1.4 \%$ & & 496 & 504 \\
\hline betterhealth (proportion reporting) & $14.6 \%$ & $13.5 \%$ & $14.8 \%$ & $15.0 \%$ & $02 \%$ & & 496 & 504 \\
\hline $\begin{array}{l}\text { change in health (proportion im proving less proportion } \\
\text { w orsening) }\end{array}$ & $-39 \%$ & $-32 \%$ & $-3.8 \%$ & $-5.0 \%$ & $12 \%$ & & 496 & 504 \\
\hline $\begin{array}{l}\text { Self-esteem and satisfaction } w \text { ith life } \\
\text { change in satisfaction } w \text { ith life }(-4 \text { to }+4)\end{array}$ & 0.05 & 0.03 & 0.04 & 0.08 & -0.04 & & 623 & 616 \\
\hline in provem ent in satisfaction $w$ ith life (proportion reporting) & $22.8 \%$ & $20.1 \%$ & $22.4 \%$ & $21.9 \%$ & $0.4 \%$ & & 623 & 616 \\
\hline reduction in satisfaction $w$ ith life (proportion reporting) & $209 \%$ & $18.7 \%$ & $209 \%$ & $182 \%$ & $2.7 \%$ & & 623 & 616 \\
\hline $\begin{array}{l}\text { change in life satisfaction (proportion im proving less } \\
\text { proportion w orsening) }\end{array}$ & $19 \%$ & $15 \%$ & $15 \%$ & $3.7 \%$ & $-22 \%$ & & 623 & 616 \\
\hline change in self-esteem (scale -24 to +24 ) & 0.41 & 0.06 & 0.48 & 0 & 0.48 & & 623 & 616 \\
\hline $\begin{array}{l}\text { net change in self-esteem (proportion im proving less } \\
\text { proportion w orsening) }\end{array}$ & $79 \%$ & $2.4 \%$ & $89 \%$ & $-11 \%$ & $101 \%$ & & 623 & 616 \\
\hline $\begin{array}{l}\text { A ctivities w ith children } \\
\text { netchange in proportion of sam ple helping children to read }\end{array}$ & $-6.4 \%$ & $-5.9 \%$ & $-6.4 \%$ & $-6.6 \%$ & $02 \%$ & & 125 & 187 \\
\hline
\end{tabular}




\begin{tabular}{|c|c|c|c|c|c|c|c|c|}
\hline Changes betw een $\mathrm{W}$ ave 1 and $\mathrm{W}$ ave 3 & $\begin{array}{l}\text { unm atch } \\
\text { leamers } \\
\text { value }\end{array}$ & $\begin{array}{l}\text { non- } \\
\text { leamers } \\
\text { value }\end{array}$ & $\begin{array}{l}\mathrm{m} \text { atched } \\
\text { leamers } \\
\text { value }\end{array}$ & $\begin{array}{l}\text { non- } \\
\text { leamers } \\
\text { value }\end{array}$ & difference & $\begin{array}{l}\text { Signifi- } \\
\text { cant }\end{array}$ & No of ok & $\begin{array}{l}\text { ations } \\
\text { non- } \\
\text { leamers }\end{array}$ \\
\hline $\begin{array}{l}\text { net change in proportion of sam ple helping children w th } \\
\text { w riting }\end{array}$ & $-6.0 \%$ & $-0.5 \%$ & $-6.8 \%$ & $3.7 \%$ & $-10.5 \%$ & & 133 & 189 \\
\hline $\begin{array}{l}\text { change in helping children w ith hom ew ork (large negative }-3 \\
\text { to large positive }+3 \text { ) }\end{array}$ & -0.37 & -02 & -0.35 & -0.41 & 0.06 & & 178 & 241 \\
\hline change in no of days peryear read story to chitdren & -55 & -22 & -57 & -26 & -31 & & 116 & 156 \\
\hline $\begin{array}{l}\text { Education and training } \\
\text { change in com } m \text { itm ent to education and training } \\
\text { (scale }-16 \text { to }+16 \text { ) }\end{array}$ & 0.91 & 0.86 & 0.93 & 03 & 0.63 & $\star \star$ & 623 & 616 \\
\hline proportion cumently on an education or training course & $48.8 \%$ & $10.1 \%$ & $481 \%$ & $11.1 \%$ & $369 \%$ & & 623 & 616 \\
\hline
\end{tabular}




\begin{tabular}{|c|c|c|c|c|c|c|c|c|}
\hline O theroutcom es (notdifference in differences) & $\begin{array}{l}\text { unm atche } \\
\text { leamers } \\
\text { value }\end{array}$ & $\begin{array}{l}\text { non- } \\
\text { leamers } \\
\text { value } \\
\end{array}$ & $\begin{array}{l}\text { m atched } \\
\text { leamers } \\
\text { vahue }\end{array}$ & $\begin{array}{l}\text { non- } \\
\text { leamers } \\
\text { value }\end{array}$ & difference & $\begin{array}{l}\text { Signifi- } \\
\text { cant }\end{array}$ & No of ob & $\begin{array}{l}\text { non- } \\
\text { leamers }\end{array}$ \\
\hline $\begin{array}{l}\text { Self-perceived changes in literacy and num eracy overpastye } \\
\text { net proportion reporting self-perceived in provem ent in } \\
\text { literacy in pastyear }\end{array}$ & $70.0 \%$ & $32.6 \%$ & $69.4 \%$ & $50.1 \%$ & $1920 \%$ & ** & 623 & 616 \\
\hline $\begin{array}{l}\text { net proportion reporting self-perceived in provem ent in } \\
\text { num eracy in pastyear }\end{array}$ & $562 \%$ & $231 \%$ & $55.7 \%$ & $28.7 \%$ & $2710 \%$ & ** & 623 & 616 \\
\hline $\begin{array}{l}\text { self-perceived im provem ent in num eracy in pastyear } \\
\text { (average of } 0=\text { no im provem ent, } 1=\text { som e im } p, 2=\text { def } \mathrm{im} \text { ) }\end{array}$ & 0.84 & 029 & 0.83 & 0.37 & 0.46 & $* *$ & 623 & 616 \\
\hline $\begin{array}{l}\text { self perceived in provem ent in literacy in pastyear } \\
\text { (average of } 0=\text { no in provem ent, } 1=\text { som e im } p, 2=\operatorname{def} \text { im } p \text { ) }\end{array}$ & 11 & 0.45 & 11 & 0.7 & 0.39 & ** & 623 & 616 \\
\hline
\end{tabular}

** indicates significantat5\% level 


\section{$R$ eferences}

Beder, H . (1999) The Outcom es and Impacts of Adult Literacy Education in the U nited States, N ational Centre for the Study of A dult Leaming and Literacy (NCSA LL) Reportno 6, http: /w w w ncsallnet/fileadm in/resources/research/report6 podf

$B$ hundell R and Costa D ias M (2000) Evaluation M ethods for $N$ on-experim ental D ata, F iscalstudies 21 (4) pp 427-468

Boe R (1997) A Two-Year Follow -Up of Federal O ffenders who Participated in the Adult Basic Education (ABE) Program, Ottawa: Conrectional Service of Canada R esearch Report no $R-60$

Bonjour D and Sm eaton D (2003) The Im pact of A dult Basic Skills Pathfinder Extension A ctivities: stage 2 of the evaluation. London: Departm ent for Education and Ski7ls R esearch Reportno 238.

Brooks, G ., Davies, R ., Duckett, L., Hutchison, D ., Kendall, S. and W ilkin, A . (2001a) Progress in Adult Literacy: Do leamers leam? London: The Basic Skills A gency.

B rooks, G ., G iles, K ., H arm an, J., Kendall, S ., Rees, F . and W hittaker, S . (2001b) Assem bling the Fragm ents: A Review of Research on AdultBasic Skills. D fEE Research ReportN o 220. London: D fES .

Bynner, J. and Parsons, S . (1997a) It D oesn't G et A ny Better: The Im pact of poor Basic Skills on the lives of 37 year-olds.

Bynner, J. and Parsons, S. (1997b) D oes N um eracy M atter, London: Basic Skills A gency.

Bynner J, M cIntosh S , V ignoles A, D earden L, Reed H and V an Reenen J (2001) Improving Adult Basic Skills: Benefits to the Individual and to Society, D fEE Research Centre W ider B enefits of Leaming, Reportno 251

D earden, L ., M cIntosh, L ., M yck, M ., and V ignoles, A . (2000). The Retums to Academ ics, Vocational and Basic Skills in Britain, D FEE research report no. 192 , D FEE , N ottingham

D enny KJ, H arm on CP and O 'Sullivan V (2003) Functional Literacy, Educational A ttainm ent and Eamings: A M ulti-Country Comparison, U niversity College D ublin Centre forEconom ic Research W olking PaperW P03/19

D fEE (1999) A F resh Start - improving literacy and num eracy. London: D epartm ent forEducation and Skills. (A lso know $n$ as the M oserR eport)

Ekinsm yth, C . and Bynner, J. (1994) The Basic Skills of Y oung A dults, London: Basic Ski7ls A gency

Fingeret, H . A . (1985). North Carolina adult basic education instructional program evaluation. Raleigh, NC: North Carolina State D epartm ent of Com m unity Colleges.

Fingeret, H ., \& D rennon, C . (1997). Literacy for life: Adult leamers, new practices. $\mathrm{N}$ ew Y olk: Teachers College Press.

Fingeret. H . A ., and Danin, S. T . (1991). They really put a hurtin' on my brain: Leaming in Literacy Volunteers of New York City. Raleigh, NC : Literacy South. 
Gorm an, T. and M oss, N . (1979). Survey of A ttainm ent and Progress in A dult L iteracy Schem es. Slough: N FER .

H eckm an J, Lalonde RJ and Sm th J (1999) The Econom ics and Econom etrics of A ctive Labour M arket Program $\mathrm{s}$, in A shenfelter $O$ and Card D (eds) $\mathrm{H}$ andbook of Labour Econom ics vol IIIa, A m sterdam : $\mathrm{N}$ orth $\mathrm{H}$ olland

H eckm an JJ, Ichim ura H and Todd PR (1997) M atching as an Econom etric O utcom e Evahuation Estim ator: Evidence from Evahuating a Job Training Program, Review ofEconom ic Studies, 64, pp 605-54

Heckm an J, Sm th J and Clem ents N (1997) M aking The M ost out of Social Programme Evaluations and Social Experim ents: A ccounting for heterogeneity in program $m$ e im pacts, Review of Econom ic Studies 64 (4)

$\mathrm{H}$ eckm an J and Sm ith JA (1995) A ssessing the Case for Social Experim ents, Joumal of Econom ic Perspectives 9 (2) pp 85-110

H eath, S B . (1983). W ays w ith words: Life and work in com m unities and classroom S, $\mathrm{N}$ ew Y ork: Cam bridge U niversity Press.

HM Inspectorate of Education (2005) Changing Lives: Adult Literacy and Num eracy in Scotland

M achin S M cIntosh S V ignoles A and V iitanen A (2001) Basic Ski7ls, Soft Skills and Labour M arket Outcomes: Secondary Analysis of the National Child D evelopm ent Study, Centre for the Econom ics of Education Research report no 250 .

M cIntosh, S. (2004, unpublished) Literacy Review of the E ffects of Improvem ents in AdultB asic Skills. Report Prepared for the N ationalA ssem bly of W ales.

M eadow S, P. and M etcalf, H . (2005) Evaluation of the Impact of Skiths for Life Leaming: Report on Sweep 2. D fES Research Report 701. London: D fES. http://w w w dfes.gov .uk/research/data/uploadfiles/RR 701 ,pdf

M etcalf, H . and M eadow S, P. (2005) Evaluation of the Impact of Skills for Life Leaming: Report on $\mathrm{W}$ ave 1. London: DfES. http: / $w$ w w dfes.gov .uk/research/data/uploadfiles/RW 50 .pdf

OECD (2000) Literacy in the Information Age: Final Report of the Intemational AdultLiteracy Survey, Paris: OECD

Rahm aniz , CrosierT and Pollack S (2002) Evaluating the Impactof the Literacy and Num eracy Training Programme for Job Seekers, Canbena: D epartm ent of Education, Science and Training, R esearch A nalysis and Evaluation G roup

Rosenbaum PR and Rubin D B (1983) The Central Role of the Propensity Score in O bservational Studies for C ausal E ffects, B iom etrika 70 (1) pp 41-55

Rosenberg, M . (1965). Society and the Adolescent Self-image. Princeton, N J: Princeton U niversity Press.

Sm ith D J, M CV ie S, W oodw ard R, Shute J, Flint J, and M CA ra L (2001) The Edinburgh Study of Youth Transitions and Crim e: Key findings at age 12 and 13 http:/ $/ \mathrm{w}$ w w law .ed ac.uk/cls/esytc/findingsreporthtm

Venables W M and R ipley BD (1999) M odem Applied Statistics with S-P hus, 3rd Edition, Springer 
Copies of this publication can be obtained from:

DfES Publications

P.O. Box 5050

Sherwood Park

Annesley

Nottingham

NG15 ODJ

Tel: 08456022260

Fax: 08456033360

Minicom: 08456055560

Online: www.dfespublications.gov.uk

(C) Crown Copyright 2007

Produced by the Department for Education and Skills

ISBN 9781844788804

Ref No: RR824

www.dfes.go.uk/research 